\title{
Evidence of a Role for Three Neuropeptides that Mediate Steroid Negative Feedback on Gonadotropin Releasing Hormone/ Luteinizing Hormone Secretion in the Ewe: Kisspeptin, Neurokinin $B$ and Orphanin FQ
}

Casey C. Nestor

West Virginia University

Follow this and additional works at: https://researchrepository.wvu.edu/etd

\section{Recommended Citation}

Nestor, Casey C., "Evidence of a Role for Three Neuropeptides that Mediate Steroid Negative Feedback on Gonadotropin Releasing Hormone/Luteinizing Hormone Secretion in the Ewe: Kisspeptin, Neurokinin B and Orphanin FQ" (2012). Graduate Theses, Dissertations, and Problem Reports. 4903.

https://researchrepository.wvu.edu/etd/4903

This Dissertation is protected by copyright and/or related rights. It has been brought to you by the The Research Repository @ WVU with permission from the rights-holder(s). You are free to use this Dissertation in any way that is permitted by the copyright and related rights legislation that applies to your use. For other uses you must obtain permission from the rights-holder(s) directly, unless additional rights are indicated by a Creative Commons license in the record and/ or on the work itself. This Dissertation has been accepted for inclusion in WVU Graduate Theses, Dissertations, and Problem Reports collection by an authorized administrator of The Research Repository @ WVU.

For more information, please contact researchrepository@mail.wvu.edu. 


\title{
Evidence of a Role for Three Neuropeptides that Mediate Steroid Negative Feedback on Gonadotropin Releasing Hormone/Luteinizing Hormone Secretion in the Ewe: Kisspeptin, Neurokinin B and Orphanin FQ
}

\author{
Casey C Nestor \\ Dissertation submitted to the School of Medicine at West Virginia University \\ in partial fulfillment of the requirements for the degree of \\ Doctor of Philosophy \\ In \\ Cellular and Integrative Physiology
}

Robert L. Goodman, PhD; Chair/Mentor

Stanley M. Hileman, PhD

John M. Connors, PhD

Jorge A. Flores, $\mathrm{PhD}$

David J. Smith, PhD

Ida Holaskova, $\mathrm{PhD}$

Cellular and Integrative Physiology Program

Morgantown, West Virginia

2012

Key Words: gonadotropin releasing hormone, luteinizing hormone, kisspeptin, neurokinin $B$, orphanin $F Q$, sheep 


\title{
ABSTRACT \\ Evidence of a Role for Three Neuropeptides that Mediate Steroid Negative Feedback on Gonadotropin Releasing Hormone/Luteinizing Hormone in the Ewe: Kisspeptin, Neurokinin B and Orphanin FQ
}

\author{
Casey C Nestor
}

Gonadotropin-releasing hormone $(\mathrm{GnRH})$ is the final common output from the central nervous system for controlling luteinizing hormone (LH) secretion from the anterior pituitary. GnRH, and subsequently LH, secretion for most of the menstrual/estrous cycle occurs in an episodic pattern that is controlled by the inhibitory actions of estradiol and progesterone. However, GnRH neurons are devoid of the appropriate steroid receptors, therefore, estradiol and progesterone must mediate their effects on GnRH/LH secretion through interneurons. Three likely candidates are neurons containing kisspeptin, neurokinin $\mathrm{B}(\mathrm{NKB})$ and orphanin FQ (OFQ).

Puberty in the ewe is marked by an increase in GnRH/LH secretion which in part results from a lessening of estradiol negative feedback. Kisspeptin and NKB are coexpressed in the same subsets of neurons in the arcuate nucleus (ARC) of the hypothalamus and are proposed to be critical for normal timing of puberty. Given that greater than $95 \%$ of kisspeptin/NKB neurons colocalize with estrogen receptor- $\alpha(\mathrm{ER} \alpha)$ and progesterone receptor in the ewe, we examined changes in kisspeptin- and NKBpositive neurons in the ARC of pre- and postpubertal ewes in the presence and absence of sex steroids. We observed a greater number of kisspeptin, but not NKB, positive neurons in the ARC of postpubertal ewes compared to prepubertal ewes, which corresponded with changes in LH secretion. Also, we showed that an intravenous injection of senktide, an NKB receptor agonist, stimulates LH secretion in prepubertal ewes. These results support a role for kisspeptin and NKB in ovine puberty.

OFQ when given centrally has been shown to inhibit LH secretion in rats and ewes and OFQ localizes to the external zone of the median eminence. Given its effect on LH secretion and its location, we investigated whether OFQ acts at the pituitary to inhibit LH release and/or at the hypothalamus to inhibit GnRH secretion. OFQ had no direct influence on ovine anterior pituitary cells in cell culture. 
However, we did observe a decrease in GnRH secretion in hypophyseal portal blood samples following infusion of an OFQ agonist into the third cerebroventricle of ovariectomized ewes. From this we conclude that OFQ acts centrally at the hypothalamus to inhibit GnRH secretion.

Given its central inhibitory action on GnRH secretion in the ewe, we examined if OFQ neurons in the preoptic area (POA) and hypothalamus contain steroid receptors. Furthremore, we investigated a role for endogenous OFQ by infusing an OFQ receptor antagonist into steroid-treated ewes. POA OFQ neurons did not contain steroid receptors, while a majority of OFQ neurons in the ARC contained both ER $\alpha$ and progesterone receptor. Furthermore, ovariectomized (OVX) ewes with luteal phase concentrations of progesterone and estradiol, but not OVX ewes implanted with only estradiol or ovaryintact anestrous ewes, showed a significant increase in LH pulse frequency during infusion of an OFQ receptor antagonist. Therefore, we conclude that OFQ mediates, at least in part, the negative feedback action of progesterone on GnRH/LH secretion in the ewe. 


\section{DEDICATION}

I dedicate this collection to the men and women who donated their bodily remains to further the education and wellbeing of generations to come.

Respectfully yours, Casey C Nestor 


\section{ACKNOWLEDGEMENTS}

Let me take a moment to recognize several individuals that have made this work possible. I'll do my best to include all those that participated in my doctoral education.

I walked into Bob Goodman's office almost eight years ago hoping to gain insight into what research had to offer. I never knew that he would have the patience to put up with me for this long. To say the least he deserves many thanks for all the hours of surgical expertise, repeated explanations, continuous funding and the congratulatory drinks following many successful, and some not so successful, experiments. Thanks Bob for being an excellent mentor and a wonderful friend. With help from Stan Hileman I gained better editorial and surgical skills and learned how to laugh at myself while pulling a second golf ball from my pocket. He helped bring me home safely from Slovakia and for that my mother thanks him. I thank John Connors who gave me my first opportunity to teach and provided excellent surgical advice. He is full of great humor and from May to July each year has one of the best looking lawns in Morgantown. Ida Holaskova was sentenced to share an office with me for two years. I thank her for listening to my personal and profession ideas. Stan, John and Ida joined forces in an attempt to teach me statistics. I still use the 'eye squared' test, but can follow it with legitimate statistical analysis. Jorge Flores brought his in vitro expertise to the table reminding me that specificity should be one of my main priorities. Dave Smith contributed with pharmacological advice and kept me thinking, as did all of my committee members, in terms of the big picture. I would like to thank Miro Valent for escorting Stan and I through Slovakia. He taught me the ins and outs of the farm and the laboratory from day one and treated me as if I was his own son. I thank him for all the radioimmunoassays and for the pictures throughout the years. Also, I'm thankful for his wife's wonderful cooking. Those apple things are delicious. Gail Nesselrod had to endure hours of bad language and even worse jokes. I thank her for all her help working with the sheep. Sushma Singh and Adrienne Bogusz warned me about what I was getting myself into and I didn't listen. I thank them for their help early in my degree with experimental design and friendly encouragement. Karen Martin was a great help in navigating the imaging facility. I 
would like to thank Paul Harton for tissue sectioning. Lori Groover, Mary Copeland and Imogene Kelly deserve thanks for helping me schedule a conference room, which always seemed to be at the very last minute. Frank McGreevy inspired me to teach and for this I thank him. He was a true joy to have for class and I enjoy our occasional correspondence. Last, but certainly not least, I would like to thank my parents, Mom and Pop. They provided me the opportunity to grow in a loving environment focusing on the importance of education. My father taught me anticipate what tool was needed next and adapt to any unforeseen complications. My mother taught me to show compassion and patience for people and animals, which proves very handy in large animal research. Over the years I have acquired a combination of my parent's personalities and cannot thank them enough for giving me a place to live. For anyone I forgot I apologize, but it has been a true pleasure and honor to work with everyone from the very beginning. Thanks again, Casey 


\section{ABBREVIATIONS}

\begin{tabular}{|c|c|}
\hline GnRH & Gonadotropin-Releasing Hormone \\
\hline $\mathrm{LH}$ & Luteinizing Hormone \\
\hline OFQ & Orphanin FQ \\
\hline $\mathrm{NKB}$ & Neurokinin B \\
\hline ARC & Arcuate nucleus \\
\hline OVX & Ovariectomized \\
\hline POA & Preoptic area \\
\hline FSH & Follicle Stimulating Hormone \\
\hline AHA & Anterior Hypothalamic Area \\
\hline $\mathrm{ER} \alpha$ & Estrogen Receptor-alpha \\
\hline PR & Progesterone Receptor \\
\hline $\mathrm{OVX}+\mathrm{E}_{2}$ & Ovariectomy plus estradiol treatment \\
\hline EOP & Endogenous opioid peptides \\
\hline $\mathrm{OVX}+\mathrm{P}$ & Ovariectomy plus progesterone treatment \\
\hline $\mathrm{OVX}+\mathrm{P}+\mathrm{E}_{2}$ & Ovariectomy plus progesterone plus estradiol treatment \\
\hline $\mathrm{MBH}$ & Medial Basal Hypothalamus \\
\hline ME & Median Eminence \\
\hline ORL-1 & Opioid-Receptor Like-1 \\
\hline NK3R & Neurokinin 3 Receptor \\
\hline GPR54 & G-coupled protein receptor 54 \\
\hline OVLT & Organum Vasculosum of the Lamina Terminalis \\
\hline AVPV & Anteroventral Periventricular Nucleus \\
\hline VMH & Ventromedial Hypothalamus \\
\hline $\mathrm{EF}$ & Early Follicular \\
\hline mPOA & medial Preoptic Area \\
\hline
\end{tabular}




$\begin{array}{ll}\text { RIA } & \text { Radioimmunoassay } \\ \text { GNDX } & \text { Gonadectomized } \\ \text { DAB } & \text { 3,3'-diaminobenzidine tetrahydrochloride } \\ \text { POMC } & \text { Proopiomelanocortin } \\ \text { TH } & \text { Tyrosine Hydroxylase } \\ \text { AgRP } & \text { Agouti-related Peptide } \\ \text { GABA } & \text { gamma-aminobutyric acid } \\ \text { icv } & \text { intracerebroventricular }\end{array}$




\section{TABLE OF CONTENTS}

Evidence for a Role of Three Neuropeptides that Mediate Steroid Negative Feedback on Gonadotropin Releasing Hormone/Luteinizing Hormone in the Ewe: Kisspeptin, Neurokinin B and Orphanin FQ...............................................................

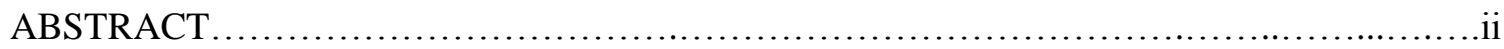

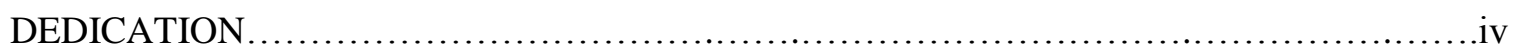

ACKNOWLEDGEMENTS .........................................................

ABREVIATIONS ..................................................................vii

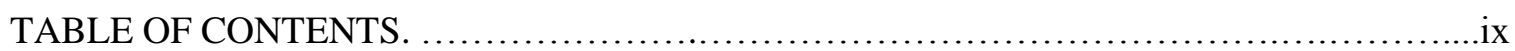

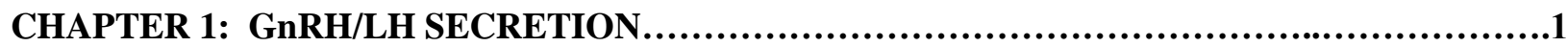

GONADOTROPIN-RELEASING HORMONE: ANATOMY AND FUNCTION $\ldots \ldots \ldots \ldots \ldots . . .2$

FEEDBACK CONTROL OF GnRH AND LH DURING THE OVARIAN CYCLE $\ldots \ldots \ldots \ldots \ldots . . . . .3$

ROLE OF CHANGES IN STEROID NEGATIVE FEEDBACK IN PUBERTY AND

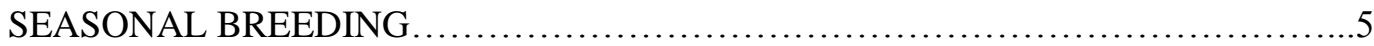

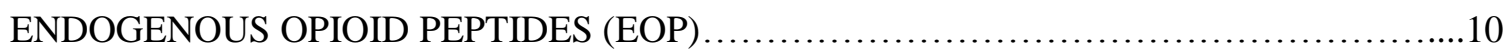

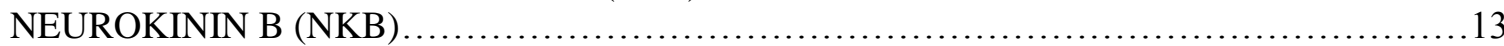

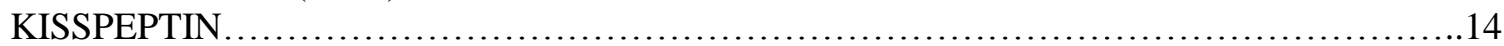

POSSIBLE ROLES FOR KISSPEPTIN AND NKB IN PUBERTY ONSET $\ldots \ldots \ldots \ldots \ldots \ldots \ldots . \ldots \ldots$

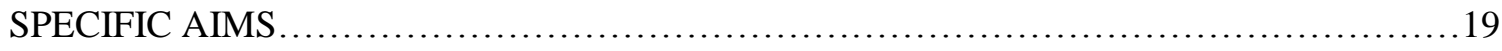

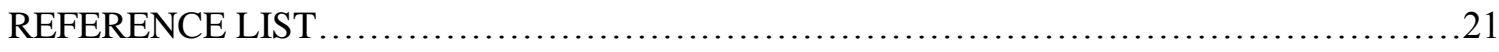

CHAPTER 2: EVIDENCE OF A ROLE FOR KISSPEPTIN AND NEUROKININ B IN PUBERTY OF FEMALE SHEEP.............................................43

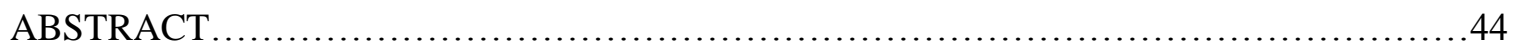

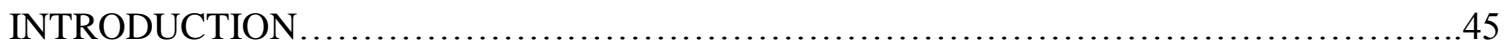

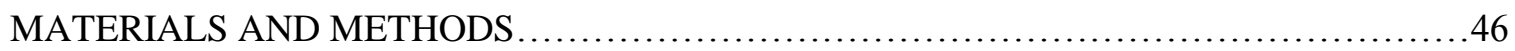

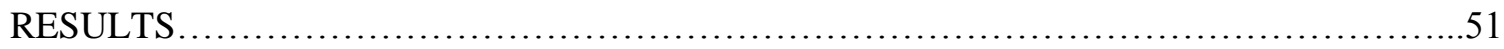

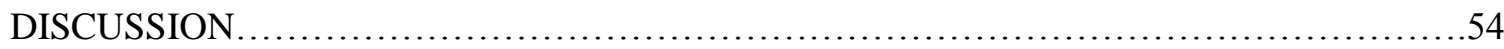

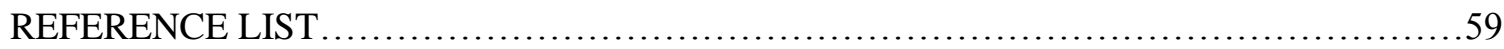

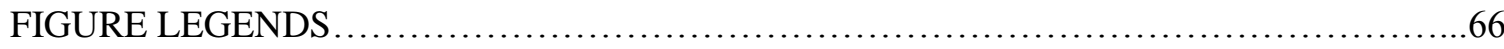

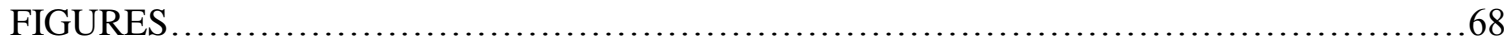

CHAPTER 3: ORPHANIN FQ ACTS AT THE HYPOTHALAMUS TO SUPPRESS

GONADOTROPIN RELEASING HORMONE SECRETION IN THE EWE.......73

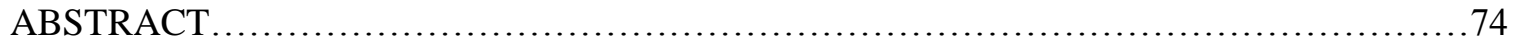

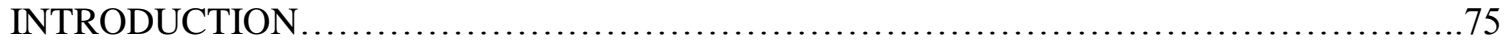

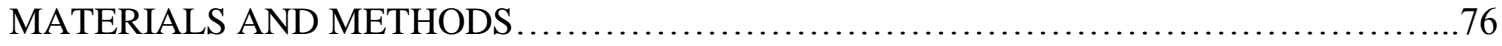

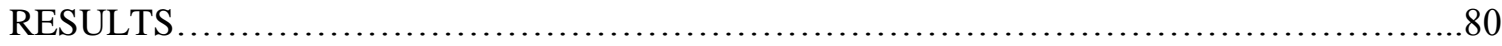

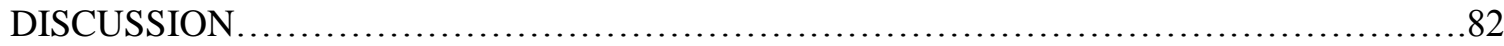

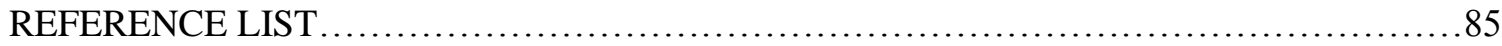

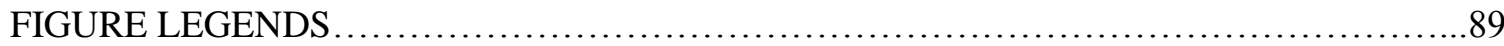

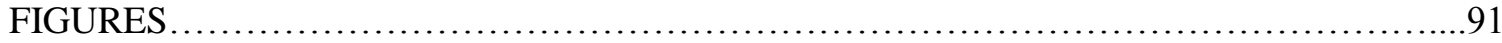


CHAPTER 4: EVIDENCE THAT ORPHANIN FQ MEDIATES PROGESTERONE NEGATIVE FEEDBACK IN THE EWE........................................98

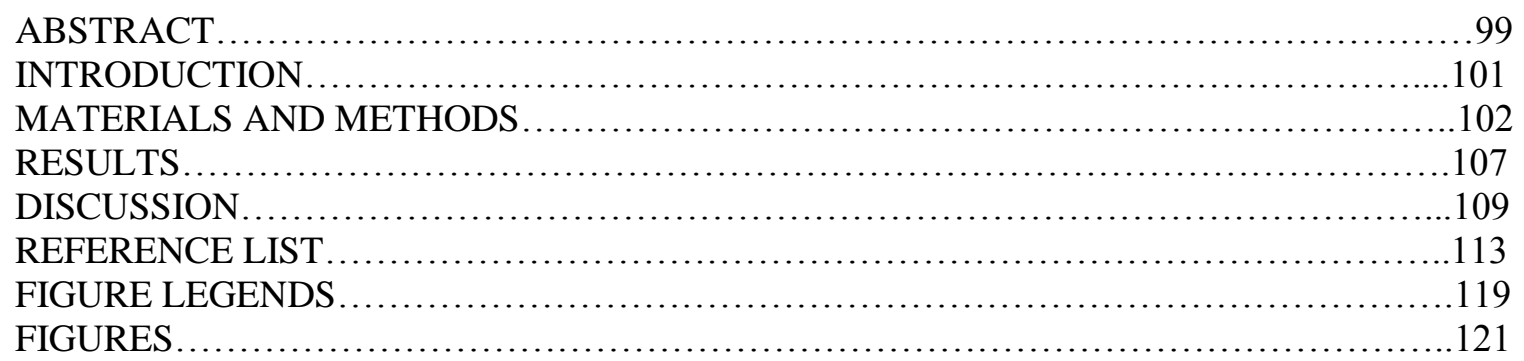

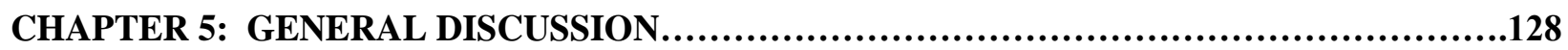

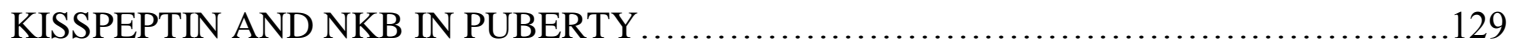

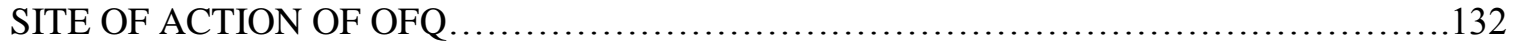

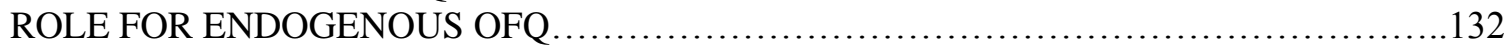

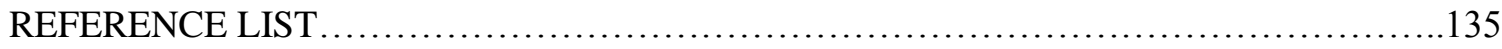

PERMISSION TO REPRODUCE COPYRIGHT MATERIALS.............................137

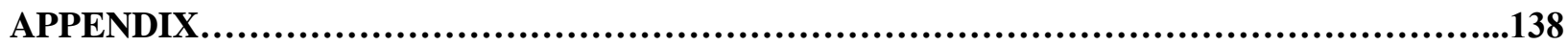

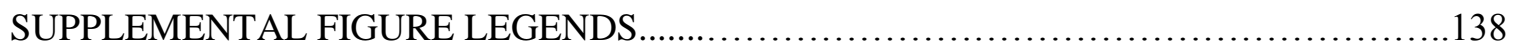

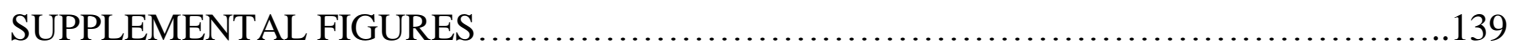

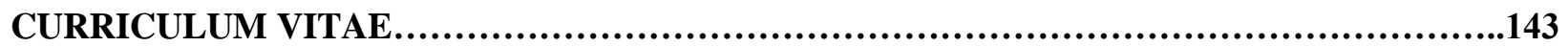


CHAPTER 1

GnRH/LH SECRETION 


\section{GONADOTROPIN-RELEASING HORMONE: ANATOMY AND FUNCTION}

Gonadotropin-releasing hormone $(\mathrm{GnRH})$ is the final common output from the central nervous system that governs reproduction. As its name implies, GnRH stimulates the gonadotropes of the anterior pituitary to release luteinizing hormone (LH) and follicle stimulating hormone (FSH). The GnRH gene is found on chromosome 8 in humans with exon 2 encoding the GnRH decapeptide (1-3). During midgestation, GnRH neurons differentiate in the olfactory placode, then migrate through the nasal septum and enter the ventral forebrain establishing an adult distribution prior to birth. In rodents, GnRH cell bodies are found almost exclusively in the preoptic area (POA) and anterior hypothalamic area (AHA), while in sheep and primates, GnRH perikarya are found in the POA, AHA and medial basal hypothalamus (MBH;(4)). In rats and sheep, an equal percentage of GnRH neurons from the before mentioned areas send projections to the external zone of the median eminence (ME), while in primates the ventral hypothalamic tract of the $\mathrm{MBH}$ has the greatest percentage of neuroendocrine $\mathrm{GnRH}$ projections (5-8).

Once secreted, GnRH enters a network of fenestrated capillaries in the external zone of the ME and travels to the anterior pituitary via the hypophyseal portal veins where it acts via a G-coupled protein receptor to stimulate the synthesis and secretion of LH and FSH. In the female, gonadotropin action depends upon the targeted structure in the ovary (follicle and corpus luteum). During the follicular phase, LH and FSH stimulate follicles in the ovary to develop and produce estradiol. During the luteal phase, LH stimulates the corpus luteum to produce progesterone and, in some species, estradiol. These steroids, estradiol and progesterone, complete a negative feedback loop by inhibiting GnRH secretion at the hypothalamus as well as by inhibiting LH secretion at the pituitary. Since GnRH and LH secretion closely coincide throughout most of the estrous cycle, these two hormones are commonly referred to in tandem (i.e., GnRH/LH)

The estrous cycle in ewes (9) and the menstrual cycle in primates (10), averages 16 to 17 and 28 days, respectively, and consist of two phases, follicular and luteal, each named for its dominant ovarian structure. The difference in cycle length between the ewe and primate is due to a shortened follicular 
phase in the ewe. During the early to mid-follicular phase, follicular growth occurs with gradually increasing GnRH/LH and estradiol concentrations, while in the late follicular phase, a large increase in estradiol leads to a large increase in $\mathrm{GnRH} / \mathrm{LH}$ secretion (the $\mathrm{GnRH} / \mathrm{LH}$ surge) which causes ovulation. Following ovum release, the remaining follicular structure becomes luteinized, forms a corpus luteum and survives for approximately 14 days producing progesterone, which keeps GnRH/LH concentrations relatively low. If fertilization does not occur, the corpus luteum regresses and the cycle begins again. The length of the estrous cycle in rodents (11) is 4 or 5 days because rodents have eliminated a normal length luteal phase. The rodent cycle can be separated into four distinct parts: metestrus, diestrus, proestrus and estrus. During metestrus and diestrus, follicular development occurs within the ovary. On the afternoon of proestrus, a large increase in LH secretion occurs and results in follicular rupture and release of an ovum; this is followed by an estrous period when the female is sexually receptive to the male. If fertilization does not occur, the reproductive cycle can begin again.

\section{FEEDBACK CONTROL OF GnRH AND LH DURING THE OVARIAN CYCLE}

During the estrous/menstrual cycle, GnRH/LH secretion occurs in two patterns: surge and tonic. LH concentrations on the afternoon of proestrous in rats can reach 200 times greater than basal levels (12, 13). The stimulus for this GnRH/LH surge in rodents appears to be estradiol. Several groups have shown that ovariectomized (OVX) rats given exogenous estradiol on the morning of proestrus respond with a surge-like release of LH similar to intact proestrous rats on the afternoon of proestrus (14-20). Also, the LH surge can be blocked by giving an estrogen antagonist (21), estradiol antiserum (22) or by OVX on diestrus (23). Also in rodents, progesterone plays a role in the timing and magnitude of the surge given that administration of progesterone can advance the LH surge a few hours and dramatically increase its amplitude in estrogen primed rats on the day of proestrous, but not on other days of the estrous cycle (24). Therefore, in rodents both estradiol and progesterone act together to elicit GnRH/LH surge secretion. In sheep and primates, estadiol alone appears to be the driving stimulus for the GnRH/LH surge. The GnRH/LH surge is preceded by elevated estradiol concentrations in ewes (25) and female monkeys (26). Furthermore, estradiol alone is enough to induce a GnRH/LH surge in OVX sheep $(27,28)$ and 
monkeys (29-33). Also, immunoneutralization of estradiol can block the surge in intact, cycling monkeys (34) and ewes (35-39). In contrast to rodents, progesterone does not appear to play an analogous role in these species. In the ewe, increasing the circulating concentrations of progesterone during the follicular phase does not accelerate the timing of the surge (40). Furthermore, a progesterone receptor antagonist, RU486, fails to block surge induction in sheep (41). Although having no stimulatory effects on the LH surge in these species, progesterone, if present, can block the GnRH/LH surge in sheep (42) and primates $(34,43-45)$. However, the fall in progesterone following regression of the corpus luteum appears to contribute to the timing of the GnRH/LH surge in ewes given that prolonging the elevation in progesterone concentrations by progesterone administration can delay the timing of the surge in ewes (46). Nonetheless, as intriguing as GnRH/LH surge secretion may be, my experimental focus herein will be placed solely on the regulation of GnRH/LH secretion by steroid negative feedback in the ewe.

For most of the estrous cycle in rodents and sheep as well as most of the menstrual cycle in primates, GnRH/LH secretion occurs in a pulsatile pattern, consisting of brief episodes of secretion separated by relatively long periods of no secretion (i.e., tonic secretion). Tonic secretion during the follicular phase consists of GnRH/LH pulses of high frequency and low amplitude, while in the luteal phase GnRH/LH pulses have a low frequency and high amplitude (47). This tonic mode of secretion in rodents appears to be primarily controlled by estradiol since estradiol alone in OVX rats or progesterone in estrogen-primed rats can suppress LH secretion, but progesterone by itself cannot (24). In sheep and monkeys, tonic $\mathrm{GnRH} / \mathrm{LH}$ secretion during the early follicular phase is controlled by the negative feedback of estradiol given that estradiol can inhibit GnRH/LH pulse amplitude, while increasing pulse frequency in OVX ewes $(48,49)$ and monkeys $(50)$. In sheep and primates, progesterone is the primary steroid responsible for controlling tonic GnRH/LH secretion during the luteal phase. Progesterone administration in OVX ewes can decrease LH pulse frequency (48), while progesterone in combination with estradiol can suppress LH secretion below detectable levels in the OVX monkey (26). Therefore, during the estrous/menstrual cycle, estradiol negative feedback inhibits GnRH/LH pulse amplitude, while progesterone negative feedback inhibits GnRH/LH pulse frequency (Figure 1). 


\section{ROLE OF CHANGES IN STEROID NEGATIVE FEEDBACK IN PUBERTY AND SEASONAL BREEDING}

Changes in steroid negative feedback can cause alterations in $\mathrm{GnRH} / \mathrm{LH}$ pulse patterns that have been shown to control important hallmarks of fertility, such as pubertal progression and seasonality. Puberty is defined as a time when the individual first gains the ability to reproduce. Regardless of species, prepubertal GnRH/LH concentrations are low with minimal GnRH/LH pulse frequency. What does differ between species is the reason for low gonadotropin levels. In the rat, OVX as early as postnatal day 6 yields maximal LH concentrations, while estradiol alone is not sufficient to suppress gonadotropin levels to prepubertal values (51). Changes in the shape of GnRH neurons (52) and other hypothalamic neurons in the ARC (53) occurs during this pubertal transition. Furthermore, the lack of elevated LH secretion prior to puberty cannot be solely accounted for by the absence of GnRH activity and estrogen receptors $(54,55)$ or at the pituitary by its inadequate response to $\mathrm{GnRH}(56)$. Therefore, the absence of LH prepubertally in rodents most likely is a combination of hypothalamic inhibition and pituitary insufficiency. In primates, the ovary appears to play little part in the prepubertal brake on $\mathrm{GnRH} / \mathrm{LH}$ secretion as removal of the ovaries in monkeys does not cause any increase in GnRH/LH secretion (57). The reason for the lack of LH secretion appears to be central in nature because exogenous pulsatile administration of GnRH stimulates LH secretion (58), thus verifying that the pituitary is not a limiting factor in puberty onset for this species.

The current working model for puberty in the ewe can be found in what has been called the gonadostat hypothesis, in which it is postulated that decreased hypothalamic release of $\mathrm{GnRH} / \mathrm{LH}$ secretion is due to steroid negative feedback from the ovary (Figure 2). Indeed, puberty in the ewe is well-defined by the increase in $\mathrm{GnRH} / \mathrm{LH}$ secretion that is followed by the first ovulation and often includes a short luteal phase followed by a complete estrous cycle (59). Prior to puberty, estradiol negative feedback is the primary contributor to the inhibition of $\mathrm{GnRH} / \mathrm{LH}$ pulse frequency. Thus, OVX of prepubertal ewes as early as 6 weeks of age increases LH pulse frequency and this can be readily reversed by estradiol replacement up until 27 weeks of age (60). In further support for the concept of 
lessening estradiol negative feedback at puberty, it has been reported that OVX ewes replaced with estradiol $\left(\mathrm{OVX}+\mathrm{E}_{2}\right)$ have $\mathrm{LH}$ concentrations below detectability until 28 weeks of age, after which LH secretion increases, at a time similar to when intact ewes begin to display estrous cycles (61). This agedependent increase of $\mathrm{LH}$ in $\mathrm{OVX}+\mathrm{E}_{2}$ ewes reflects a loss in the ability of estradiol to inhibit GnRH/LH pulse frequency (62); as noted above estradiol inhibits pulse amplitude in adult breeding season ewes. Therefore, the gonadostat hypothesis holds particularly true for the ewe with the pubertal increase in GnRH/LH pulse frequency being due to a lessening of steroid negative feedback. However, the neural systems mediating this reduction in estradiol negative feedback remains to be determined.

Another instance when GnRH/LH secretion is altered by steroid negative feedback is during photoperiod-induced (or seasonal) changes in fertility. Mice and rats are not seasonal breeders, but sheep have a distinct window of reproductive activity during the fall and winter months (63). For half of the year, non-pregnant ewes become reproductively quiescent wherein estrous cycles come to a stop (a period of time known as anestrus or the non-breeding season). The lengthening days of spring and summer bring about a reduction in $\mathrm{GnRH} / \mathrm{LH}$ secretion in the ewe caused by increased sensitivity to estradiol negative feedback as evidenced by lower LH secretion during long-day, but not short-day, photoperiods in $\mathrm{OVX}+\mathrm{E}_{2}$ ewes (64). Melatonin secretion from the pineal gland, which is only secreted at night and thus inversely proportional to the amount of daylight, appears to be driving this seasonal effect because pinealectomized $\mathrm{OVX}+\mathrm{E}_{2}$ ewes given a long-day pattern of melatonin while on a short-day photoperiod regimen have low LH secretion (65). As with puberty, the seasonal changes in response to estradiol negative feedback are reflected by a change in GnRH/LH pulse frequency (Figure 1): the effect of estradiol on $\mathrm{GnRH} / \mathrm{LH}$ secretion during anestrus is a reduction in pulse frequency, while during the breeding season it inhibits pulse amplitude (66-68). This seasonal change in the ability of estradiol to inhibit LH pulse frequency is suggestive of a primary change in the hypothalamus. Furthermore, since administration of pentobarbital, which decreases neural activity, can increase LH secretion in anestrous ewes, but not breeding season ewes (69), it has been theorized that inhibitory afferent neurons mediate the negative feedback of estradiol on GnRH/LH secretion during seasonal anestrous in the ewe. Considerable 
work has lead to idea that dopaminergic and kisspeptinergic neural systems participate in this inhibition (70).

Two figures that quite succinctly summarize the effects of steroids on LH secretion in the adult ewe during breeding and non-breeding seasons (Figure 1) and during the pubertal transition (Figure 2) can be seen on the next two pages. 
Figure 1

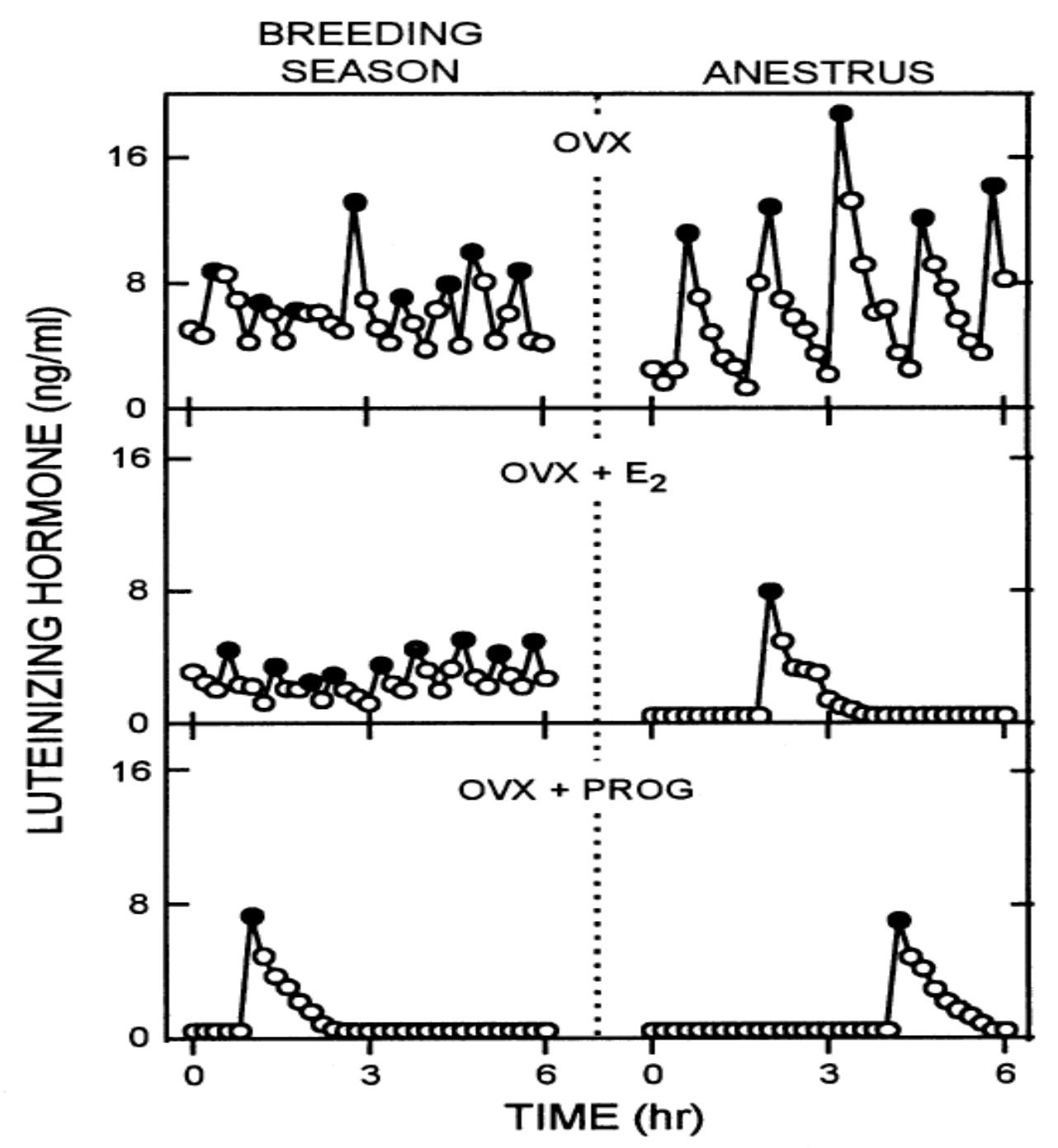

Figure 1: Effects of steroid negative feedback on LH secretion in the ewe. During the breeding season estradiol and progesterone act to inhibit GnRH/LH pulse amplitude and frequency, respectively. During anestrus, estradiol inhibits GnRH/LH pulse frequency (from (71)). 
Figure 2

\section{E negative feedback}

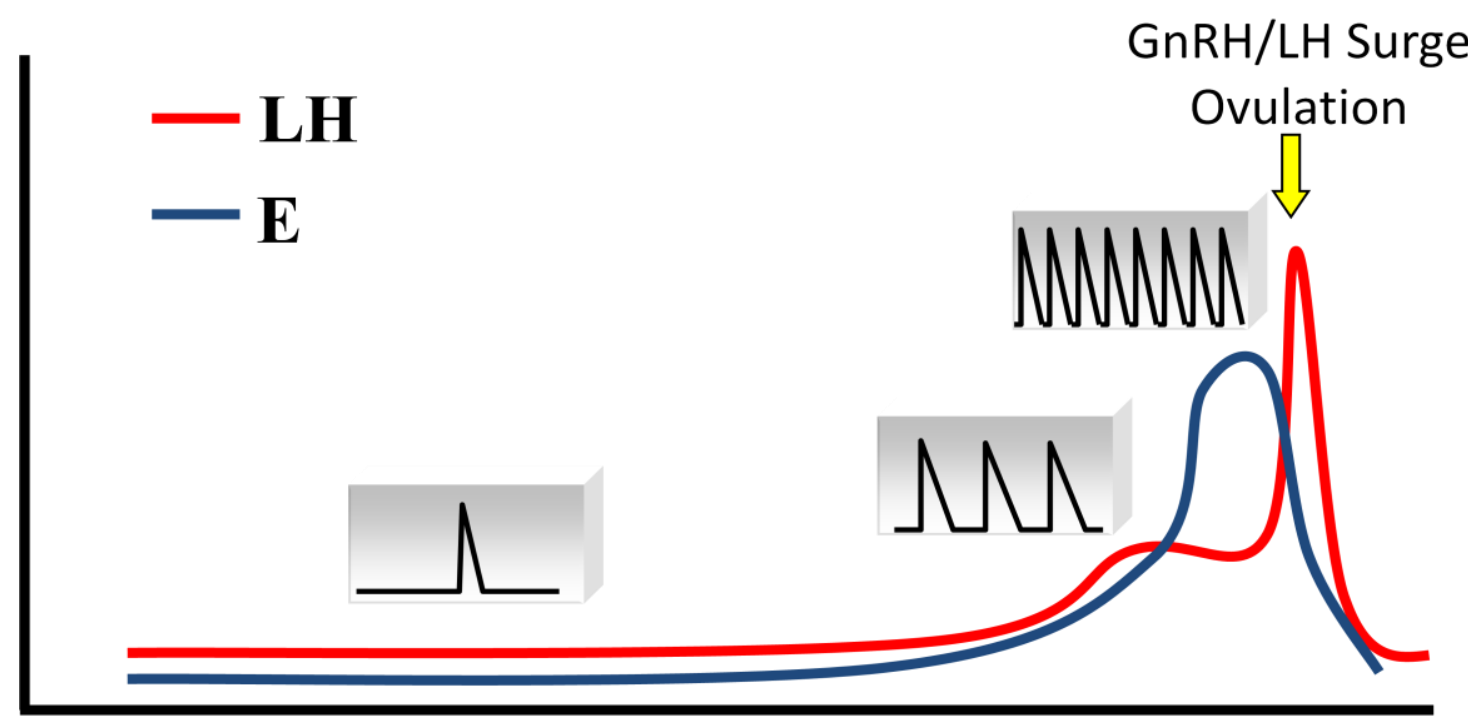

\section{Time $\longrightarrow$}

Figure 2: The gonadostat hypothesis for pubertal development in the ewe. In the prepubertal ewe, estradiol negative feedback potently inhibits GnRH/LH pulse frequency as seen in the leftmost inset with the single LH pulse. As the animal grows and matures, estradiol negative feedback lessens allowing for an increase in $\mathrm{GnRH} / \mathrm{LH}$ pulse frequency (rightmost inset) which leads to the first ovulation. 
The simplest explanation for a central inhibitory effect of estradiol or progesterone on LH secretion would be via a direct action on GnRH neurons. However, GnRH neurons are devoid of the appropriate steroid receptors, estrogen receptor- $\alpha[\mathrm{ER} \alpha ;(72,73)]$ and progesterone receptor [PR; (74)]; therefore, steroid feedback must occur through afferent neurons that have yet to be identified. Upcoming sections will consider the possible roles of three such afferent inputs, orphanin FQ (OFQ), neurokinin B (NKB) and kisspeptin, in the control of $\mathrm{GnRH} / \mathrm{LH}$ secretion. Each neuropeptide will appear in the chronological order in which they were discovered, with consideration given primarily to female rodents, sheep and primates.

\section{ENDOGENOUS OPIOID PEPTIDES (EOP)}

Endogenous opioid peptides consist primarily of three major families: enkephalins, endorphins and dynorphins. The enkephalins and endorphins preferentially bind the delta $(\delta)$ and $\mathrm{mu}(\mu)$ receptors, while the dynorphins preferentially bind kappa $(\kappa)$ receptors (75). Shortly after their discovery, evidence began to accumulate indicating that EOP were involved in steroid negative feedback.

Through the use of opioid antagonists, it is now well established that EOP contribute to control of GnRH/LH secretion. An early study in normal women reported that an infusion of naloxone, a nonspecific opioid receptor antagonist, increased LH concentrations in the late follicular and luteal phases (76). Subsequent studies in humans revealed that an infusion of naloxone increased LH concentrations in steroid-replaced women, but not in women lacking the inhibitory effect of sex steroids $(77,78)$. Such studies led to the conclusion that in humans EOP mediate steroid negative feedback. In partial agreement with the human work, in other primates naloxone increased LH secretion over two fold in luteal phase monkeys, but was without effect in follicular phase monkeys (79). Thus, in the monkey, EOP appear to mediate progesterone, but not estradiol, negative feedback. In rats, LH increases in response to naloxone treatment 2 days post OVX, which is likely due to the negative feedback that remains until steroids are cleared following OVX since these effects were absent when tested 7 and 21 days post OVX (80).

Furthermore, during early pregnancy in rats when estradiol and progesterone are elevated, naloxone 
stimulates an increase in LH secretion (81), supporting the idea that EOP can mediate steroid negative feedback on GnRH/LH secretion.

In the ewe, results from experiments with naloxone vary somewhat with increases in LH seen in ewes with high serum progesterone (82), follicular and luteal phase ewes $(83,84)$ and OVX plus progesterone $(\mathrm{OVX}+\mathrm{P})$ ewes (85). With the use of a long acting opioid antagonist, WIN 44,443-1, Whisnant and Goodman (86) reported an increase in LH pulse amplitude in follicular phase and OVX + $\mathrm{E}_{2}$ ewes as well as an increase in LH pulse frequency in luteal phase and OVX $+\mathrm{P}$ or OVX ewes with progesterone and estradiol $\left(\mathrm{OVX}+\mathrm{P}+\mathrm{E}_{2}\right)$. Yang et al. (87) showed similar results in the breeding and non-breeding season as OVX ewes exibited increased LH release following WIN 44,443-1 in the presence of progesterone alone. Since naloxone can increase GnRH pulse frequency and amplitude in luteal phase ewes (88), it was concluded that EOP could mediate progesterone and estradiol negative feedback in the ewe. However, naloxone increased GnRH pulse amplitude to the same extent in both $\mathrm{OVX}$ and $\mathrm{OVX}+\mathrm{E}_{2}$ ewes (89). Therefore, EOP do not appear to be involved in estradiol negative feedback in the ewe.

It is thus now generally accepted in the ewe, and several other species including women, that progesterone negative feedback occurs, at least in part, through EOP, however the specific EOP involved remains controversial. Knife cuts in the ewe disconnecting the POA from the MBH do not disrupt estrous cyclicity (90) nor does it affect EOP mediation of progesterone negative feedback (91). These results led researchers to investigate the role of $\mathrm{EOP}$ within the $\mathrm{MBH}$, with specific attention to the arcuate nucleus (ARC). Greater than $90 \%$ of dynorphin neurons in the ARC of the ewe contain PR (92), while $33 \%$ and $21-25 \%$ of ARC $\beta$-endorphin neurons coexpress PR in guinea pigs (93) and monkeys (94), respectively. Furthermore, in multiple species dynorphin and $\beta$-endorphin neurons synapse on GnRH neurons (95-98). Moreover, progesterone can increase preprodynorphin expression and proopiomelanocortin (POMC) mRNA (the precursor of $\beta$-endorphin) in the ewe $(99,100)$, further supporting the idea that progesterone could regulate GnRH through EOP. 
Weesner and Malven (101) demonstrated with the use of antiserum that $\beta$-endorphin inhibits LH secretion via actions in the POA and met-enkephalin acts in the MBH, while Conover et al., (102) showed, with infusion of $\beta$-endorphin, that this opioid exerts its inhibition at the median eminence. However, with the use of specific opioid antagonists for the $\mu$-, $\delta$ - and $\kappa$-receptors, Goodman et al. (95) reported an increase in LH pulse frequency only in luteal phase ewes treated with the $\kappa$-receptor antagonist. A more recent report by the same group (103) concluded that dynorphin neurons in the ARC alone may not be sufficient to account for the inhibitory effect of progesterone on LH secretion. In that study, progesterone microimplants placed into the caudal ARC to target the area where dynorphin neurons reside failed to inhibit LH secretion in the ewe. However, suppression of LH secretion with systemic administration of progesterone by constant intravaginal drug release was reversed by microimplants of a progesterone receptor antagonist, RU486, in the caudal ARC. The simplest explanation for these data is that other neurons outside the caudal ARC must also be involved in mediating progesterone negative feedback and likely form a network with dynorphin neurons. One such neuropeptide that may serve such a role is orphanin FQ (OFQ).

Overshadowed, for good reason, by other neuropeptides (kisspeptin, NKB, etc.) that will be a later focus of this literature review, OFQ has received little attention in reproduction since it was discovered by two independent groups $(104,105)$ to bind an orphan $G$ protein-coupled receptor, opioid receptor like 1 (ORL-1). OFQ has been shown to participate in various physiological processes including pain perception, learning and memory, as well as renal and cardiovascular function (106). Although OFQ shares structural similarities with dynorphin A, classic opioids do not activate ORL-1 nor does OFQ activate classic opioid receptors $(107,108)$.

In rodents, OFQ $(109,110)$ and ORL-1 $(110-112)$ are found in many areas of the central nervous system including the POA and throughout the hypothalamus. Likewise in the ewe, neurons expressing OFQ are also found in the POA and hypothalamus (113). In this same study, greater than $90 \%$ of GnRH neurons in the POA contained OFQ with each neuropeptide in separate secretory vesicles within the same neuron. OFQ-containing terminals were also present in the external zone of the ME, but separate from 
GnRH terminals. Therefore, it is possible that OFQ reaches the anterior pituitary, as does GnRH, via the hypophyseal portal veins and could have actions at the anterior pituitary.

Given the hypothalamic location of OFQ neurons and ORL-1, a number of groups have examined a role for OFQ in controlling GnRH and LH secretion. Work done with hypothalamic slice preparations in rodents has revealed that OFQ can inhibit GnRH release $(114,115)$ by increasing conductance of an inwardly-rectifying potassium channel (116). In vivo reports in the rat have also shown that intracerebroventricular (icv) administration of OFQ reduces GnRH concentrations in push-pull perfusates $(115,117)$, while administration of an OFQ receptor antagonist results in an increase in LH secretion (115). In the ewe, icv infusion of OFQ elicited a robust suppression in LH secretion (113). Although OFQ appears to affect LH through an inhibition of GnRH secretion, at least in rats, previous limitations in experimental design have made this less than a certainty. Administration via the ventricular system is a useful means of drug delivery to establish a central effect, but does not eliminate the possibility of an action at the pituitary because this gland is bathed in cerebrospinal fluid. In addition, it remains controversial as to whether or not ORL-1 is present in the anterior pituitary $(112,115,118)$. Thus, without direct pituitary assessment one cannot exclude an action of OFQ at the level of the pituitary to inhibit LH secretion.

\section{NEUROKININ B (NKB)}

Although NKB was discovered shortly after the EOP, it only recently gained increased attention following the 2009 discovery that in humans mutations in the genes that encode for NKB or its receptor, neurokinin 3 receptor (NK3R), lead to hypogonadotropic hypogonadism (119). As a member of the tachykinin family, NKB is the only peptide synthesized from the preprotachykinin-B gene $(120,121)$ and preferentially binds NK3R (122).

In rodents, NKB mRNA $(123-126)$ and protein $(123-125,127,128)$ are seen in various areas of the hypothalamus with the majority of cell bodies residing in the ARC. In sheep, NKB mRNA $(129,130)$ and protein $(129,131,132)$ are found almost exclusively within the ARC. In primates, NKB mRNA $(133,134)$ is predominantly in the infundibular nucleus, the primate homolog of the ARC, which is 
consistent with reports in women for NKB mRNA (135) and protein (136). Furthermore, NKB cell numbers within the ARC of female sheep are higher than males, which clearly results from the organizational effects of testosterone during prenatal development $(129,137)$. NKB afferent neurons project to GnRH neurons in multiple species (138). NK3R is found in several areas of the hypothalamus in rodents $(128,139)$ and sheep $(140)$ and in GnRH terminals in the ME in rats (193), but not in sheep (140).

In multiple species, ARC NKB mRNA levels are inhibited by estradiol $(130,133,141,142)$. Thus it was proposed that NKB may have a stimulatory action on GnRH/LH secretion. However, in rodents the first reported effect of senktide, an NK3R agonist, on LH secretion was inhibitory (134). With the renewed interest in the role of NKB, several new studies have reported stimulatory actions of this agonist. It now appears that the actions of senktide are largely dependent on steroid milieu. In OVX mice (126), OVX rats $(142,143)$ and OVX rats treated with low levels of estradiol (134) senktide inhibits LH secretion. In contrast, senktide stimulates LH secretion in diestrous rats $(142,143)$. Work done in non-rodent species has reported a stimulatory role for NKB on GnRH/LH secretion. In sheep, NKB and senktide can stimulate LH secretion in follicular phase and ovary-intact anestrous ewes (144). Therefore, inhibition of NKB may contribute to steroid negative feedback on GnRH/LH secretion.

\section{KISSPEPTIN}

Kisspeptin, which was discovered in 1996 (145), has created quite a stir within the field of reproductive biology. Kisspeptin was named in honor of the popular treat made in Hershey, Pennsylvania, the "Hershey's Kiss". The KiSS-1 gene encodes for a 145 amino acid peptide that is cleaved to bioactive lengths of 10,11, 13 and 54 amino acid lengths (146), collectively known as kisspeptins. Four separate groups discovered the receptor for this family to be the orphan G-coupled protein receptor 54 (GPR54; (146-149), which is now also referred to as Kiss 1r. In 2003, when two independent groups $(150,151)$ reported that mutations in the human GPR54 lead to hypogonadotropic hypogonadism, kisspeptin became, to say the least, a popular topic in neuroendocrinology. 
Several groups have shown that kisspeptin can potently stimulate LH secretion in such species as rodents $(152,153)$, sheep $(154)$, monkeys $(155)$ and humans $(156,157)$. That this stimulation of LH secretion is due to a direct stimulation of GnRH release is suggested by several observations. One, colocalization of GPR54 mRNA with GnRH neurons is greater than 90\% in female mice (158) and 78$90 \%$ in the ewe $(159,160)$. Second, GPR54 knockout mice show no increase in LH in response to exogenous kisspeptin, but are still responsive to exogenous GnRH $(151,161)$. Third, in mice kisspeptin can depolarize GnRH cell bodies in vitro (158) and stimulate GnRH release from mouse (162) and sheep (160) median eminence explants in vitro. Fourth, administration of a GnRH receptor antagonist, acyline, blocked kisspeptin effects on LH secretion (163). Lastly, following subcutaneous administration of kisspeptin, $88 \%$ of GnRH neurons in and around the organum vasculosum of the lamina terminalis (OVLT) contained c-fos, an immediate early gene product commonly used as a marker of neural activation (164). Taken together, this evidence indicates that kisspeptin stimulates GnRH neurons directly and is important for normal GnRH/LH secretion.

In all mammalian species to date, kisspeptin neurons exist in two distinct areas of the midbrain, the anteroventral periventricular nucleus (AVPV)/POA and ARC. In female rodents, kisspeptin neurons, identified by mRNA abundance $(152,165,166)$ and protein content $(166,167)$, are localized with greater number in the ARC vs the AVPV. Although there is no distinct AVPV in the ewe, kisspeptin immunoreactive cells are present in the medial POA $(168,169)$ and ARC (168-170). In women (171), kisspeptin mRNA abundance was observed in a dense population of cells within the ARC with some scattered distribution in the medial POA, which is consistent with kisspeptin protein distribution in women (136). In female monkeys, kisspeptin mRNA appears to be restricted to the ARC alone, with no detectable change in kisspeptin mRNA abundance outside the MBH (163). As with rodents, numbers of kisspeptin cells in these species are greater in the ARC than the AVPV.

The effects of steroids on kisspeptin in these two areas, ARC and AVPV/POA, has led to the hypothesis of differing roles for each kisspeptin population in control of GnRH/LH secretion. In the ARC, ovariectomy of adults results in an increase in kisspeptin mRNA levels in rodents (165), sheep 
(169) and monkeys (171), which is consistent with data in women where kisspeptin mRNA levels are greater following menopause (171). Estradiol replacement in rodents, sheep and monkeys readily reduced ARC kisspeptin mRNA levels to those of intact animals. Although progesterone alone does inhibit kisspeptin mRNA levels in the ARC, it is not sufficient to suppress kisspeptin levels to that of an intact, luteal phase ewe (169). Since greater than $90 \%$ of kisspeptin neurons within the ARC of sheep contain ER $\alpha$ (129), it is possible that estradiol controls tonic GnRH/LH secretion through kisspeptin in the ARC of multiple species.

Although, the negative feedback of estradiol generally appears to involve the ARC, the region wherein it acts to elicit the GnRH surge appears to differ between species. In rodents the positive feedback action of estradiol appears to reside in the AVPV since microimplants of estradiol in the AVPV of rats can elicit a preovulatory GnRH/LH surge (172). Multiple reports support the idea for a role of AVPV kisspeptin in estradiol positive feedback in rodents. First, kisspeptin mRNA levels in the AVPV peak on the afternoon of proestrus in rats (173) at a time when the GnRH/LH surge occurs in rodents. Second, kisspeptin mRNA levels increase in the AVPV following estradiol replacement in OVX rodents $(165,174)$. Third, colocalization of c-fos and kisspeptin in the AVPV is greatest at the time of the GnRH/LH surge (173), while kisspeptin receptor knockout mice display no increase in neuronal activity within this neural population (175). Finally, kisspeptin antiserum in the POA of rodents can block the LH surge $(166,176)$. Since nearly all kisspeptin cells in the AVPV of rodents contain ER $\alpha$ (165), estradiol may act directly on kisspeptin neurons in the AVPV to promote GnRH surge induction in rodents.

In contrast to rodents, estradiol positive feedback in sheep (177) and primates (178) occurs in the MBH since microimplants of estradiol in the ventromedial hypothalamus (VMH) and ARC can elicit a GnRH/LH surge and microimplants in the POA have no effect on LH secretion. Together with the before mentioned high degree of colocalization of ER $\alpha$ and kisspeptin in the ARC and the site of estradiol positive feedback in these species, it is highly probable that kisspeptin neurons within the ARC mediates the effects of estradiol on tonic and surge GnRH/LH secretion in sheep and primates. Interestingly, kisspeptin neurons of the ARC form a unique population because almost all kisspeptin cells express NKB 
and dynorphin, a finding that was first reported in sheep (132). Since that initial observation, a similar population of arcuate kisspeptin/NKB/dynorphin neurons has been described in female mice (126), female rats (139), goats (179) and women (136). Whether the same kisspeptin neurons participate in tonic and surge $\mathrm{GnRH} / \mathrm{LH}$ secretion or whether there are specific subpopulations for each remains to be determined.

The role of POA kisspeptin neurons in non-rodent species remains somewhat controversial. Increases in kisspeptin mRNA in both the POA and ARC during the late follicular phase of sheep have been reported (159), but others report changes only in ARC kisspeptin expression (170). Moreover, earlier studies reported that steroid replacement in OVX ewes (169) and primates (171) did not alter POA kisspeptin mRNA levels, but more recent work in ewes found that estradiol increases kisspeptin in the POA (180). Furthermore, elevated colocalization of c-fos and kisspeptin in the POA during the preovulatory surge in the ewe (181) fits with the idea that POA kisspeptin contributes to estradiol positive feedback. Nevertheless, the role of POA kisspeptin cells in sheep and primates remains to be determined. In addition to steroid effects, sexual dimorphism adds another level of complexity to kisspeptin expression. Within the AVPV of rodents, females have many more kisspeptin cells than their male counterparts $(167,173)$, a difference that is still present in gonadectomized animals $(166,182)$. These results led to the idea that sex steroids during development cause organization of this neuronal population. Within the ARC of rodents, multiple reports show no difference in kisspeptin expression between males and females $(167,182-186)$, with one recent exception in the rat ARC where kisspeptin cells numbers are greater in females than males (187). Sheep (137) and humans (136) display a sexual difference in both the POA and ARC kisspeptin populations with females having higher numbers of neurons than males. Whether the sexual dimorphism in kisspeptin content is due to organizational or activational effects of gonadal steroids remains to be determined in these species.

\section{POSSIBLE ROLES FOR KISSPEPTIN AND NKB IN PUBERTY ONSET}

A few lines of evidence make kisspeptin a prime candidate for involvement in the pubertal increase in GnRH/LH secretion. First, as mentioned before, mutations in GPR54 of humans and mice 
blocks normal pubertal development and ARC kisspeptin expression in multiple species is controlled by steroid negative feedback. Second, kisspeptin can stimulate LH secretion in prepubertal rats (153), sheep (188) and primates $(155,189)$, demonstrating that the kisspeptin/GnRH network is intact prior to puberty. Third, kisspeptin expression is greater in the AVPV with no consistent changes in ARC kisspeptin in postpubertal compared to prepubertal female mice $(158,190)$, which leads to the idea that in mice AVPV kisspeptin neurons are responsible for the pubertal increase in GnRH/LH secretion. However, recent evidence shows that ablation of kisspeptin neurons in the ARC prior to puberty at a time when AVPV kisspeptin neurons have yet to be detected can disrupt estrous cyclicity in mice (191). In the rat, kisspeptin expression in both the AVPV and ARC is greater in postpubertal compared to prepubertal females $(192,193)$. Similarly, in the monkey, kisspeptin mRNA in the MBH is greater in pubertal females compared to juvenile females (163). Together the results of these studies are strongly suggestive that kisspeptin is a gatekeeper to the pubertal increase in GnRH/LH secretion.

NKB may have a role in puberty as well. Although data for changes in NKB in relation to puberty are limited, in the mouse NKB mRNA abundance is under steroid negative feedback both prepubertally and postpubertally, but does not change across puberty (183). Furthermore, the response to $\mathrm{NKB}$ appears to be intact prior to puberty in monkeys since NKB and senktide stimulate LH secretion in prepubertal male monkeys (194). However, it remains to be determined if NKB can stimulate LH secretion in the prepubertal female. Although a direct action of NKB on GnRH might exist given that GnRH terminals in the ME contain NK3R in rats (195), several groups have investigated the possibility that NKB may act through kisspeptin to stimulate GnRH secretion. In rodents and sheep, a majority of ARC kisspeptin neurons contain NK3R $(126,139,140)$, a finding consistent with the depolarizing effect of NKB on kisspeptin neurons in whole-cell patch recordings mice (142). Also, an icv administration of senktide produces an increase in c-fos containing kisspeptin cells in the ARC of rats with no change in the AVPV (142). Furthermore, mice lacking GPR54 do not exhibit an increase in LH secretion after icv injection of senktide (196). These data support the notion that NKB acts via kisspeptin to stimulate GnRH/LH secretion. 


\section{SPECIFIC AIMS}

Given the effects of steroids on GnRH/LH secretion and that GnRH neurons are devoid of ER $\alpha$ and PR, it seems clear that other, intermediate neurons must serve to link the two. We propose three specific aims to test the roles for kisspeptin, NKB and OFQ in mediating steroid negative feedback on GnRH/LH secretion in the ewe.

Specific Aim 1: To determine if kisspeptin and/or NKB are involved in puberty onset in the ewe. We hypothesize that the kisspeptin network is intact, but merely inhibited by heightened estradiol negative feedback prior to puberty. To test this hypothesis we examined numbers of kisspeptin positive cells in the ARC of prepubertal and postpubertal ewes in the presence and absence of estradiol and used age-matched males as a control for any effect of age that might be independent of reproductive function. Furthermore, we analyzed kisspeptin close contacts onto GnRH neurons in pre- and postpubertal ewes in the presence and absence of estradiol.

Similar to kisspeptin, we hypothesize that NKB expression is inhibited by estradiol in the prepubertal ewe, but not in the adult. We tested this by examining numbers of NKB positive cells in the ARC of preand postpubertal ewes in the presence and absence of estradiol. Also, we investigated if NKB can stimulate LH secretion prior to puberty by administering senktide, an NKB receptor agonist, to prepubertal ewes.

Specific Aim 2: To determine the site where OFQ acts to inhibit LH secretion in the ewe. We hypothesize that OFQ inhibits GnRH release from the hypothalamus. To test this we administered an OFQ receptor agonist into the third ventricle of OVX ewes while simultaneously collecting hypophyseal portal blood and jugular blood for the measurement of GnRH and LH, respectively. Also, to test a direct effect at the anterior pituitary, we challenged anterior pituitary cells collected from ewes in various steroid milieus with increasing doses of GnRH in the presence or absence of OFQ.

Specific Aim 3: To determine a role for endogenous OFQ in steroid negative feedback in the ewe. We hypothesize that OFQ mediates steroid negative feedback in the ewe. To test this hypothesis, we evaluated the effect of a centrally infused OFQ receptor antagonist, UFP-101, on LH secretion in OVX + 
$\mathrm{E}_{2}$ or $\mathrm{OVX}+\mathrm{P}+\mathrm{E}_{2}$ ewes in the breeding season and ovary-intact ewes in the non-breeding season. Furthermore, in collaboration with our colleagues at The University of Michigan, we assessed colocalization of OFQ and ER $\alpha$ or PR in the POA and hypothalamus of luteal phase ewes.

As mentioned above, I am using the sheep to address my specific aims as it has several advantages for the performance of this work. First, the sheep is the only model to date that can be used to measure GnRH from hypophyseal portal blood in an unanesthetized animal. This technique allows for simultaneous collection of portal and jugular blood to determine if effects are central via alterations in GnRH secretion or at the level of the pituitary and will be used in Chapter 3 to evaluate the third ventricle infusion of an OFQ agonist. Second, with a relatively large blood volume compared to rodents, sheep can be bled multiple times per hour for several hours to analyze GnRH and/or LH pulse amplitude and pulse frequency. We will analyze LH pulse dynamics in Chapters 2-4 and GnRH pulse dynamics in Chapter 3. Third, if neural tissue is not needed immediately following treatment, each animal can be used for multiple treatments (with some limitation) allowing each ewe to serve as its own control, which will be used in Chapter 4 with the infusion of an OFQ receptor antagonist. Finally, sheep have a larger hypothalamus and pituitary relative to rodents. The former allows for more detailed anatomical analysis, which we use to our advantage in Chapters 2 and 4 to examine multiple POA and hypothalamic sections for immunocytochemical labeling of various neuropeptides, and the latter produces a greater number of anterior pituitary cells for cell dispersion in the in vitro examination of OFQ effects on LH release as seen in Chapter 3. 


\section{REFERENCE LIST}

1. Seeburg PH, Adelman JP 1984 Characterization of cDNA for precursor of human luteinizing hormone releasing hormone. Nature 311:666-668

2. Adelman JP, Mason AJ, Hayflick JS, Seeburg PH 1986 Isolation of the gene and hypothalamic cDNA for the common precursor of gonadotropin-releasing hormone and prolactin release-inhibiting factor in human and rat. Proc Natl Acad Sci U S A 83:179-183

3. Williamson P, Lang J, Boyd Y 1991 The gonadotropin-releasing hormone (Gnrh) gene maps to mouse chromosome 14 and identifies a homologous region on human chromosome 8 . Somat Cell Mol Genet 17:609-615

4. Silverman AJ 1994 The Gonadotropin-Releasing Hormone (GnRH), Neuronal Systems: Immunocytochemistry and In Situ Hybridization. In: Knobil E ed. The Physiology of Reproduction. 2nd ed. New York: Raven Press; 1683-1709

5. Jennes L, Stumpf WE 1986 Gonadotropin-releasing hormone immunoreactive neurons with access to fenestrated capillaries in mouse brain. Neuroscience 18:403-416

6. Silverman AJ, Jhamandas J, Renaud LP 1987 Localization of luteinizing hormone-releasing hormone (LHRH) neurons that project to the median eminence. J Neurosci 7:2312-2319

7. Goldsmith PC, Thind KK, Song T, Kim EJ, Boggant JE 1990 Location of the neuroendocrine gonadotropin-releasing hormone neurons in the monkey hypothalamus by retrograde tracing and immunostaining. J Neuroendocrinol 2:157-168

8. Jansen HT, Hileman SM, Lubbers LS, Kuehl DE, Jackson GL, Lehman MN 1997 Identification and distribution of neuroendocrine gonadotropin-releasing hormone neurons in the ewe. Biol Reprod 56:655-662

9. Goodman RL 2006 Neuroendocrine Control of the Ovarian Cycle of the Sheep. In: Neill JD ed. Physiology of Reproduction. 3rd ed. New York: Academic Press; 2389-2447

10. Zeleznik AJ 2006 Control of Follicular Development, Corpus Luteum Function, the Maternal Recognition of Pregnancy, and the Neuroendocrine Regulation of the Menstrual Cycle in Higher 
Primates. In: Neill JD ed. Physiology of Reproduction. 3rd ed. New York: Academic Press; 24492510

11. Freeman ME 2006 Neuroendocrine Control of the Ovarian Cycle of the Rat. In: Neill JD ed. Physiology of Reproduction. 3rd ed. New York: Academic Press; 2327-2388

12. Blake CA 1976 A detailed characterization of the proestrous luteinizing hormone surge. Endocrinology 98:445-450

13. Fox SR, Smith MS 1985 Changes in the pulsatile pattern of luteinizing hormone secretion during the rat estrous cycle. Endocrinology 116:1485-1492

14. Banks JA, Freeman ME 1978 The temporal requirement of progesterone on proestrus for extinction of the estrogen-induced daily signal controlling luteinizing hormone release in the rat. Endocrinology 102:426-432

15. Banks JA, Freeman ME 1980 Inhibition of the daily LH release mechanism by progesterone acting at the hypothalamus. Biol Reprod 22:217-222

16. Banks JA, Mick C, Freeman ME 1980 A possible cause for the differing responses of the luteinizing hormone surge mechanism of ovariectomized rats to short term exposure to estradiol. Endocrinology 106:1677-1681

17. Caligaris L, Astrada JJ, Taleisnik S 1971 Release of luteinizing hormone induced by estrogen injection into ovariectomized rats. Endocrinology 88:810-815

18. Freeman ME, LaRochelle FT, Jr., Moore RB 1976 Effect of thyroid status on spontaneous and induced surges of luteinizing hormone. Endocrinology 99:713-719

19. Jackson GL 1972 Blockage of progesterone-induced relase of luteinizing hormone by actinomycin-D or reserpine and comparison of effects of progesterone and estrogen on release of luteinizing hormone in the rat. Endocrinology 90:874-879

20. Legan SJ, Coon GA, Karsch FJ 1975 Role of estrogen as initiator of daily LH surges in the ovariectomized rat. Endocrinology 96:50-56 
21. Shirley B, Wolinsky J, Schwartz NB 1968 Effects of a single injection of an estrogen antagonist on the estrous cycle of the rat. Endocrinology 82:959-968

22. Ferin M, Tempone A, Zimmering PE, Van de Wiele RL 1969 Effect of antibodies to 17betaestradiol and progesterone on the estrous cycle of the rat. Endocrinology 85:1070-1078

23. Schwartz NB 1964 Acute Effects of Ovariectomy on Pituitary Lh, Uterine Weight, and Vaginal Cornification. Am J Physiol 207:1251-1259

24. Caligaris L, Astrada JJ, Taleisnik S 1971 Biphasic effect of progesterone on the release of gonadotropin in rats. Endocrinology 89:331-337

25. Goodman RL, Pickover SM, Karsch FJ 1981 Ovarian feedback control of follicle-stimulating hormone in the ewe: evidence for selective suppression. Endocrinology 108:772-777

26. Karsch FJ, Weick RF, Hotchkiss J, Dierschke DJ, Knobil E 1973 An analysis of the negative feedback control of gonadotropin secretion utilizing chronic implantation of ovarian steroids in ovariectomized rhesus monkeys. Endocrinology 93:478-486

27. Radford HM, Wheatley IS, Wallace AL 1969 The effects of oestradiol benzoate and progesterone on secretion of luteinizing hormone in the ovariectomized ewe. J Endocrinol $44: 135-136$

28. Scaramuzzi RJ, Lindsay DR, Shelton JN 1971 The effect of oestradiol benzoate on the duration of oestrous behaviour in the ovariectomized ewe. J Endocrinol 50:345-346

29. Knobil E 1974 On the control of gonadotropin secretion in the rhesus monkey. Recent Prog Horm Res 30:1-46

30. Marut EL, Williams RF, Cowan BD, Lynch A, Lerner SP, Hodgen GD 1981 Pulsatile pituitary gonadotropin secretion during maturation of the dominant follicle in monkeys: estrogen positive feedback enhances the biological activity of LH. Endocrinology 109:2270-2272

31. Karsch FJ, Weick RF, Butler WR, Dierschke DJ, Krey LC, Weiss G, Hotchkiss J, Yamaji T, Knobil E 1973 Induced LH surges in the rhesus monkey: strength-duration characteristics of the estrogen stimulus. Endocrinology 92:1740-1747 
32. Clifton DK, Steiner RA, Resko JA, Spies HG 1975 Estrogen-induced gonadotropin release in ovariectomized rhesus monkeys and its advancement by progesterone. Biol Reprod 13:190-194

33. Schenken RS, Williams RF, Hodgen GD 1990 Effect of 20 alpha-dihydroxyprogesterone on the estrogen-induced bioactive luteinizing hormone surge in ovariectomized monkeys. Fertil Steril 54:1146-1149

34. Spies HG, Niswender GD 1972 Effect of progesterone and estradiol on LH release and ovulation in Rhesus monkeys. Endocrinology 90:257-261

35. Pant HC, Rawlings NC 1973 Proceedings: The effect of active immunization against oestradiol17beta on plasma gonadotrophin concentrations in sheep. J Reprod Fertil 35:610-611

36. Fairclough RJ, Smith JF, Peterson AJ 1976 Passive immunization against oestradiol-17beta and its effect on luteolysis, oestrus and ovulation in the ewe. J Reprod Fertil 48:169-171

37. Rawlings NC, Pant HC, Ward WR 1978 The effect of passive immunization against oestrogens on the onset of parturition in the ewe. J Reprod Fertil 54:363-367

38. Pant HC, Dobson H, Ward WR 1978 Effect of active immunization against oestrogens on plasma gonadotrophins in the ewe and the response to synthetic oestrogen or LH. J Reprod Fertil $53: 241-248$

39. Scaramuzzi RJ, Tillson SA, Thorneycroft IH, Caldwell BV 1971 Action of exogenous progesterone and estrogen on behavioral estrus and luteinizing hormone levels in the ovariectomized ewe. Endocrinology 88:1184-1189

40. Baird DT, Scaramuzzi RJ 1976 Changes in the secretion of ovarian steroid and pituitary luteinizing hormone in the peri-ovulatory period in the ewe: the effect of progesterone. $\mathrm{J}$ Endocrinol 70:237-245

41. Skinner DC, Bouchard P, Caraty A 1999 The progesterone blockade of the luteinizing hormone surge is overcome by RU486. J Neuroendocrinol 11:637-641 
42. Kasa-Vubu JZ, Dahl GE, Evans NP, Thrun LA, Moenter SM, Padmanabhan V, Karsch FJ 1992 Progesterone blocks the estradiol-induced gonadotropin discharge in the ewe by inhibiting the surge of gonadotropin-releasing hormone. Endocrinology 131:208-212

43. Spies HG, Niswender GD 1971 Blockade of the surge of preovulatory serum luteinizing hormone and ovulation with exogenous progesterone in cycling rhesus (Macaca mulatta) monkeys. J Clin Endocrinol Metab 32:309-316

44. Dierschke DJ, Yamaji T, Karsch FJ, Weick RF, Weiss G, Knobil E 1973 Blockade by progesterone of estrogen-induced LH and FSH release in the rhesus monkey. Endocrinology 92:1496-1501

45. March CM, Goebelsmann U, Nakamura RM, Mishell DR, Jr. 1979 Roles of estradiol and progesterone in eiliciting the midcycle luteinizing hormone and follicle-stimulating hormone surges. J Clin Endocrinol Metab 49:507-513

46. Skinner DC, Harris TG, Evans NP 2000 Duration and amplitude of the luteal phase progesterone increment times the estradiol-induced luteinizing hormone surge in ewes. Biol Reprod 63:1135-1142

47. Moenter SM, Caraty A, Locatelli A, Karsch FJ 1991 Pattern of gonadotropin-releasing hormone $(\mathrm{GnRH})$ secretion leading up to ovulation in the ewe: existence of a preovulatory $\mathrm{GnRH}$ surge. Endocrinology 129:1175-1182

48. Goodman RL, Karsch FJ 1980 Pulsatile secretion of luteinizing hormone: differential suppression by ovarian steroids. Endocrinology 107:1286-1290

49. Evans NP, Dahl GE, Glover BH, Karsch FJ 1994 Central regulation of pulsatile gonadotropinreleasing hormone $(\mathrm{GnRH})$ secretion by estradiol during the period leading up to the preovulatory GnRH surge in the ewe. Endocrinology 134:1806-1811

50. Yamaji T, Dierschke DJ, Bhattacharya AN, Knobil E 1972 The negative feedback control by estradiol and progesterone of LH secretion in the ovariectomized rhesus monkey. Endocrinology 90:771-777 
51. Ojeda SR, Kalra PS, McCann SM 1975 Further studies on the maturation of the estrogen negative feedback on gonadotropin release in the female rat. Neuroendocrinology 18:242-255

52. Wray S, Hoffman G 1986 Postnatal morphological changes in rat LHRH neurons correlated with sexual maturation. Neuroendocrinology 43:93-97

53. Matsumoto A, Arai Y 1976 Developmental changes in synaptic formation in the hypothalamic arcuate nucleus of female rats. Cell Tissue Res 169:143-156

54. Andrews WW, Ojeda SR 1977 On the feedback actions of estrogen on gonadotropin and prolactin release in infantile female rats. Endocrinology 101:1517-1523

55. Andrews WW, Ojeda SR 1978 Control of luteinizing hormone release in prepubertal female rats: evidence for an enhanced ability of the hypothalamus to release luteinizing hormone releasing hormone as the pituitary responsiveness to luteinizing hormone releasing hormone declines. J Endocrinol 78:281-282

56. Ojeda SR, Jameson HE, McCann SM 1977 Developmental changes in pituitary responsiveness to luteinizing hormone-releasing hormone $(\mathrm{LHRH})$ in the female rat: ovarian-adrenal influence during the infantile period. Endocrinology 100:440-451

57. Pohl CR, deRidder CM, Plant TM 1995 Gonadal and nongonadal mechanisms contribute to the prepubertal hiatus in gonadotropin secretion in the female rhesus monkey (Macaca mulatta). $\mathrm{J}$ Clin Endocrinol Metab 80:2094-2101

58. Wildt L, Marshall G, Knobil E 1980 Experimental induction of puberty in the infantile female rhesus monkey. Science 207:1373-1375

59. Ryan KD, Goodman RL, Karsch FJ, Legan SJ, Foster DL 1991 Patterns of circulating gonadotropins and ovarian steroids during the first periovulatory period in the developing sheep. Biol Reprod 45:471-477

60. Foster DL 1988 Regulation of Puberty in the Lamb: internal and external cues. In: H. Imura KS, and S. Yoshida ed. Progress in Endocrinology. Amsterdam: Elsevier; 861-866 
61. Foster DL, Ryan KD, Goodman RL, Legan SJ, Karsch FJ, Yellon SM 1986 Delayed puberty in lambs chronically treated with oestradiol. J Reprod Fertil 78:111-117

62. Ebling FJ, Kushler RH, Foster DL 1990 Pulsatile LH secretion during sexual maturation in the female sheep: photoperiodic regulation in the presence and absence of ovarian steroid feedback as determined in the same individual. Neuroendocrinology 52:229-237

63. Yeates NT 1947 Influence of variation in length of day upon the breeding season in sheep. Nature 160:429

64. Legan SJ, Karsch FJ, Foster DL 1977 The endocrin control of seasonal reproductive function in the ewe: a marked change in response to the negative feedback action of estradiol on luteinizing hormone secretion. Endocrinology 101:818-824

65. Woodfill CJ, Wayne NL, Moenter SM, Karsch FJ 1994 Photoperiodic synchronization of a circannual reproductive rhythm in sheep: identification of season-specific time cues. Biol Reprod $50: 965-976$

66. Martin GB, Scaramuzzi RJ 1983 The induction of oestrus and ovulation in seasonally anovular ewes by exposure to rams. J Steroid Biochem 19:869-875

67. Goodman RL, Bittman EL, Foster DL, Karsch FJ 1982 Alterations in the control of luteinizing hormone pulse frequency underlie the seasonal variation in estradiol negative feedback in the ewe. Biol Reprod 27:580-589

68. Barrell GK, Moenter SM, Caraty A, Karsch FJ 1992 Seasonal changes of gonadotropinreleasing hormone secretion in the ewe. Biol Reprod 46:1130-1135

69. Goodman RL, Meyer SL 1984 Effects of pentobarbital anesthesia on tonic luteinizing hormone secretion in the ewe: evidence for active inhibition of luteinizing hormone in anestrus. Biol Reprod 30:374-381

70. Goodman RL, Jansen HT, Billings HJ, Coolen LM, Lehman MN 2010 Neural systems mediating seasonal breeding in the ewe. J Neuroendocrinol 22:674-681 
71. Goodman RL 1996 Neural systems mediating the negative feedback actions of estradiol and progesterone in the ewe. Acta Neurobiol Exp (Wars) 56:727-741

72. Herbison AE, Robinson JE, Skinner DC 1993 Distribution of estrogen receptorimmunoreactive cells in the preoptic area of the ewe: co-localization with glutamic acid decarboxylase but not luteinizing hormone-releasing hormone. Neuroendocrinology 57:751-759

73. Lehman MN, Karsch FJ 1993 Do gonadotropin-releasing hormone, tyrosine hydroxylase-, and beta-endorphin-immunoreactive neurons contain estrogen receptors? A double-label immunocytochemical study in the Suffolk ewe. Endocrinology 133:887-895

74. Skinner DC, Caraty A, Allingham R 2001 Unmasking the progesterone receptor in the preoptic area and hypothalamus of the ewe: no colocalization with gonadotropin-releasing neurons. Endocrinology 142:573-579

75. Raynor K, Kong H, Chen Y, Yasuda K, Yu L, Bell GI, Reisine T 1994 Pharmacological characterization of the cloned kappa-, delta-, and mu-opioid receptors. Mol Pharmacol 45:330334

76. Quigley ME, Yen SS 1980 The role of endogenous opiates in LH secretion during the menstrual cycle. J Clin Endocrinol Metab 51:179-181

77. Shoupe D, Montz FJ, Lobo RA 1985 The effects of estrogen and progestin on endogenous opioid activity in oophorectomized women. J Clin Endocrinol Metab 60:178-183

78. Casper RF, Alapin-Rubillovitz S 1985 Progestins increase endogenous opioid peptide activity in postmenopausal women. J Clin Endocrinol Metab 60:34-36

79. Van Vugt DA, Bakst G, Dyrenfurth I, Ferin M 1983 Naloxone stimulation of luteinizing hormone secretion in the female monkey: influence of endocrine and experimental conditions. Endocrinology 113:1858-1864

80. Bhanot R, Wilkinson M 1983 Opiatergic control of LH secretion is eliminated by gonadectomy. Endocrinology 112:399-401 
81. Devorshak-Harvey E, Bona-Gallo A, Gallo RV 1987 Endogenous opioid peptide regulation of pulsatile luteinizing hormone secretion during pregnancy in the rat. Neuroendocrinology 46:369378

82. Malven PV, Bossut DF, Diekman MA 1984 Effects of naloxone and electroacupuncture treatment on plasma concentrations of LH in sheep. J Endocrinol 101:75-80

83. Currie WD, Rawlings NC 1987 Naloxone enhances LH but not FSH release during various phases of the estrous cycle in the ewe. Life Sci 41:1207-1214

84. Brooks AN, Lamming GE, Lees PD, Haynes NB 1986 Opioid modulation of LH secretion in the ewe. J Reprod Fertil 76:693-708

85. Brooks AN, Haynes NB, Yang K, Lamming GE 1986 Ovarian steroid involvement in endogenous opioid modulation of LH secretion in seasonally anoestrous mature ewes. J Reprod Fertil 76:709-715

86. Whisnant CS, Goodman RL 1988 Effects of an opioid antagonist on pulsatile luteinizing hormone secretion in the ewe vary with changes in steroid negative feedback. Biol Reprod 39:1032-1038

87. Yang K, Haynes NB, Lamming GE, Brooks AN 1988 Ovarian steroid hormone involvement in endogenous opioid modulation of LH secretion in mature ewes during the breeding and nonbreeding seasons. J Reprod Fertil 83:129-139

88. Horton RJ, Cummins JT, Clarke IJ 1987 Naloxone evokes large-amplitude GnRH pulses in luteal-phase ewes. J Reprod Fertil 81:277-286

89. Goodman RL, Parfitt DB, Evans NP, Dahl GE, Karsch FJ 1995 Endogenous opioid peptides control the amplitude and shape of gonadotropin-releasing hormone pulses in the ewe. Endocrinology 136:2412-2420

90. Jackson GL, Leshin LS, Schillo KK 1986 Effect of frontal hypothalamic deafferentation on duration of breeding season and melatonin secretion in the ewe. Biol Reprod 35:1277-1288 
91. Whisnant CS, Goodman RL 1994 Effect of anterior hypothalamic deafferentation on the negative feedback of gonadal steroids on luteinizing hormone pulse frequency in the ewe. Domest Anim Endocrinol 11:151-159

92. Foradori CD, Coolen LM, Fitzgerald ME, Skinner DC, Goodman RL, Lehman MN 2002 Colocalization of progesterone receptors in parvicellular dynorphin neurons of the ovine preoptic area and hypothalamus. Endocrinology 143:4366-4374

93. Olster DH, Blaustein JD 1990 Immunocytochemical colocalization of progestin receptors and beta-endorphin or enkephalin in the hypothalamus of female guinea pigs. J Neurobiol 21:768-780

94. Bethea CL, Widmann AA 1996 Immunohistochemical detection of progestin receptors in hypothalamic beta-endorphin and substance P neurons of steroid-treated monkeys. Neuroendocrinology 63:132-141

95. Goodman RL, Coolen LM, Anderson GM, Hardy SL, Valent M, Connors JM, Fitzgerald ME, Lehman MN 2004 Evidence that dynorphin plays a major role in mediating progesterone negative feedback on gonadotropin-releasing hormone neurons in sheep. Endocrinology $145: 2959-2967$

96. Chen WP, Witkin JW, Silverman AJ 1989 beta-Endorphin and gonadotropin-releasing hormone synaptic input to gonadotropin-releasing hormone neurosecretory cells in the male rat. $\mathrm{J}$ Comp Neurol 286:85-95

97. Chen WP, Witkin JW, Silverman AJ 1990 Sexual dimorphism in the synaptic input to gonadotropin releasing hormone neurons. Endocrinology 126:695-702

98. Thind KK, Goldsmith PC 1988 Infundibular gonadotropin-releasing hormone neurons are inhibited by direct opioid and autoregulatory synapses in juvenile monkeys. Neuroendocrinology 47:203-216

99. Whisnant CS, Curto K, Goodman RL 1992 Immunocytochemical localization of beta endorphin and gonadal steroid regulation of proopiomelanocortin messenger ribonucleic acid in the ewe. Neuroendocrinology 56:812-821 
100. Foradori CD, Goodman RL, Adams VL, Valent M, Lehman MN 2005 Progesterone increases dynorphin a concentrations in cerebrospinal fluid and preprodynorphin messenger ribonucleic Acid levels in a subset of dynorphin neurons in the sheep. Endocrinology 146:1835-1842

101. Weesner GD, Malven PV 1990 Intracerebral immunoneutralization of beta-endorphin and metenkephalin disinhibits release of pituitary luteinizing hormone in sheep. Neuroendocrinology $52: 382-388$

102. Conover CD, Kuljis RO, Rabii J, Advis JP 1993 Beta-endorphin regulation of luteinizing hormone-releasing hormone release at the median eminence in ewes: immunocytochemical and physiological evidence. Neuroendocrinology 57:1182-1195

103. Goodman RL, Holaskova I, Nestor CC, Connors JM, Billings HJ, Valent M, Lehman MN, Hileman SM 2011 Evidence that the arcuate nucleus is an important site of progesterone negative feedback in the ewe. Endocrinology 152:3451-3460

104. Reinscheid RK, Nothacker HP, Bourson A, Ardati A, Henningsen RA, Bunzow JR, Grandy DK, Langen H, Monsma FJ, Jr., Civelli O 1995 Orphanin FQ: a neuropeptide that activates an opioidlike G protein-coupled receptor. Science 270:792-794

105. Meunier JC, Mollereau C, Toll L, Suaudeau C, Moisand C, Alvinerie P, Butour JL, Guillemot JC, Ferrara P, Monsarrat B, et al. 1995 Isolation and structure of the endogenous agonist of opioid receptor-like ORL1 receptor. Nature 377:532-535

106. Mogil JS, Pasternak GW 2001 The molecular and behavioral pharmacology of the orphanin FQ/nociceptin peptide and receptor family. Pharmacol Rev 53:381-415

107. Bunzow JR, Saez C, Mortrud M, Bouvier C, Williams JT, Low M, Grandy DK 1994 Molecular cloning and tissue distribution of a putative member of the rat opioid receptor gene family that is not a mu, delta or kappa opioid receptor type. FEBS Lett 347:284-288

108. Mollereau C, Parmentier M, Mailleux P, Butour JL, Moisand C, Chalon P, Caput D, Vassart G, Meunier JC 1994 ORL1, a novel member of the opioid receptor family. Cloning, functional expression and localization. FEBS Lett 341:33-38 
109. Neal CR, Jr., Mansour A, Reinscheid R, Nothacker HP, Civelli O, Watson SJ, Jr. 1999 Localization of orphanin FQ (nociceptin) peptide and messenger RNA in the central nervous system of the rat. J Comp Neurol 406:503-547

110. Houtani T, Nishi M, Takeshima H, Sato K, Sakuma S, Kakimoto S, Ueyama T, Noda T, Sugimoto T 2000 Distribution of nociceptin/orphanin FQ precursor protein and receptor in brain and spinal cord: a study using in situ hybridization and X-gal histochemistry in receptor-deficient mice. J Comp Neurol 424:489-508

111. Anton B, Fein J, To T, Li X, Silberstein L, Evans CJ 1996 Immunohistochemical localization of ORL-1 in the central nervous system of the rat. J Comp Neurol 368:229-251

112. Neal CR, Jr., Mansour A, Reinscheid R, Nothacker HP, Civelli O, Akil H, Watson SJ, Jr. 1999 Opioid receptor-like (ORL1) receptor distribution in the rat central nervous system: comparison of ORL1 receptor mRNA expression with (125)I-[(14)Tyr]-orphanin FQ binding. J Comp Neurol 412:563-605

113. Foradori CD, Amstalden M, Coolen LM, Singh SR, McManus CJ, Handa RJ, Goodman RL, Lehman MN 2007 Orphanin FQ: evidence for a role in the control of the reproductive neuroendocrine system. Endocrinology 148:4993-5001

114. Dhandapani KM, Brann DW 2002 Orphanin FQ inhibits GnRH secretion from rat hypothalamic fragments but not GT1-7 neurons. Neuroreport 13:1247-1249

115. An XF, Chen HP, Ma SL, Feng Y, Hao JW, Chen BY 2005 Involvement of nociceptin/orphanin FQ in release of hypothalamic GnRH mediated by ORL1 receptor in ovariectomized rats. Acta Pharmacol Sin 26:1039-1044

116. Wagner EJ, Ronnekleiv OK, Grandy DK, Kelly MJ 1998 The peptide orphanin FQ inhibits beta-endorphin neurons and neurosecretory cells in the hypothalamic arcuate nucleus by activating an inwardly-rectifying K+ conductance. Neuroendocrinology 67:73-82 
117. An XF, He M, Feng Y, Feng H, Yu JY 2009 Central administration of Orphanin FQ inhibits GnRH secretion by ORL1 receptor in the median eminence of freely moving ovariectomized rats. Neurosci Bull 25:1-6

118. Foradori CD 2004 The Orphanin FQ Receptor, Opioid Receptor Like-1, is Expressed in the GT1-7 Cells and Pituitary. Society for Neurosciency, Washington, D.C., 2004

119. Topaloglu AK, Reimann F, Guclu M, Yalin AS, Kotan LD, Porter KM, Serin A, Mungan NO, Cook JR, Ozbek MN, Imamoglu S, Akalin NS, Yuksel B, O'Rahilly S, Semple RK 2009 TAC3 and TACR3 mutations in familial hypogonadotropic hypogonadism reveal a key role for Neurokinin B in the central control of reproduction. Nat Genet 41:354-358

120. Kotani H, Hoshimaru M, Nawa H, Nakanishi S 1986 Structure and gene organization of bovine neuromedin K precursor. Proc Natl Acad Sci U S A 83:7074-7078

121. Bonner TI, Affolter HU, Young AC, Young WS, 3rd 1987 A cDNA encoding the precursor of the rat neuropeptide, neurokinin B. Brain Res 388:243-249

122. Maggi CA, Schwartz TW 1997 The dual nature of the tachykinin NK1 receptor. Trends Pharmacol Sci 18:351-355

123. Lucas LR, Hurley DL, Krause JE, Harlan RE 1992 Localization of the tachykinin neurokinin B precursor peptide in rat brain by immunocytochemistry and in situ hybridization. Neuroscience $51: 317-345$

124. Marksteiner J, Sperk G, Krause JE 1992 Distribution of neurons expressing neurokinin B in the rat brain: immunohistochemistry and in situ hybridization. J Comp Neurol 317:341-356

125. Duarte CR, Schutz B, Zimmer A 2006 Incongruent pattern of neurokinin B expression in rat and mouse brains. Cell Tissue Res 323:43-51

126. Navarro VM, Gottsch ML, Chavkin C, Okamura H, Clifton DK, Steiner RA 2009

Regulation of gonadotropin-releasing hormone secretion by kisspeptin/dynorphin/neurokinin B neurons in the arcuate nucleus of the mouse. J Neurosci 29:11859-11866 
127. Merchenthaler I, Maderdrut JL, O'Harte F, Conlon JM 1992 Localization of neurokinin B in the central nervous system of the rat. Peptides 13:815-829

128. Krajewski SJ, Burke MC, Anderson MJ, McMullen NT, Rance NE 2010 Forebrain projections of arcuate neurokinin B neurons demonstrated by anterograde tract-tracing and monosodium glutamate lesions in the rat. Neuroscience 166:680-697

129. Goubillon ML, Forsdike RA, Robinson JE, Ciofi P, Caraty A, Herbison AE 2000 Identification of neurokinin B-expressing neurons as an highly estrogen-receptive, sexually dimorphic cell group in the ovine arcuate nucleus. Endocrinology 141:4218-4225

130. Pillon D, Caraty A, Fabre-Nys C, Bruneau G 2003 Short-term effect of oestradiol on neurokinin B mRNA expression in the infundibular nucleus of ewes. J Neuroendocrinol 15:749753

131. Foradori CD, Amstalden M, Goodman RL, Lehman MN 2006 Colocalisation of dynorphin a and neurokinin B immunoreactivity in the arcuate nucleus and median eminence of the sheep. $\mathrm{J}$ Neuroendocrinol 18:534-541

132. Goodman RL, Lehman MN, Smith JT, Coolen LM, de Oliveira CV, Jafarzadehshirazi MR, Pereira A, Iqbal J, Caraty A, Ciofi P, Clarke IJ 2007 Kisspeptin neurons in the arcuate nucleus of the ewe express both dynorphin A and neurokinin B. Endocrinology 148:5752-5760

133. Abel TW, Voytko ML, Rance NE 1999 The effects of hormone replacement therapy on hypothalamic neuropeptide gene expression in a primate model of menopause. J Clin Endocrinol Metab 84:2111-2118

134. Sandoval-Guzman T, Rance NE 2004 Central injection of senktide, an NK3 receptor agonist, or neuropeptide Y inhibits LH secretion and induces different patterns of Fos expression in the rat hypothalamus. Brain Res 1026:307-312

135. Chawla MK, Gutierrez GM, Young WS, 3rd, McMullen NT, Rance NE 1997 Localization of neurons expressing substance $\mathrm{P}$ and neurokinin $\mathrm{B}$ gene transcripts in the human hypothalamus and basal forebrain. J Comp Neurol 384:429-442 
136. Hrabovszky E, Ciofi P, Vida B, Horvath MC, Keller E, Caraty A, Bloom SR, Ghatei MA, Dhillo WS, Liposits Z, Kallo I 2010 The kisspeptin system of the human hypothalamus: sexual dimorphism and relationship with gonadotropin-releasing hormone and neurokinin B neurons. Eur J Neurosci 31:1984-1998

137. Cheng G, Coolen LM, Padmanabhan V, Goodman RL, Lehman MN 2010 The kisspeptin/neurokinin B/dynorphin (KNDy) cell population of the arcuate nucleus: sex differences and effects of prenatal testosterone in sheep. Endocrinology 151:301-311

138. Lehman MN, Coolen LM, Goodman RL 2010 Minireview: kisspeptin/neurokinin B/dynorphin (KNDy) cells of the arcuate nucleus: a central node in the control of gonadotropin-releasing hormone secretion. Endocrinology 151:3479-3489

139. Burke MC, Letts PA, Krajewski SJ, Rance NE 2006 Coexpression of dynorphin and neurokinin B immunoreactivity in the rat hypothalamus: Morphologic evidence of interrelated function within the arcuate nucleus. J Comp Neurol 498:712-726

140. Amstalden M, Coolen LM, Hemmerle AM, Billings HJ, Connors JM, Goodman RL, Lehman MN 2010 Neurokinin 3 receptor immunoreactivity in the septal region, preoptic area and hypothalamus of the female sheep: colocalisation in neurokinin B cells of the arcuate nucleus but not in gonadotrophin-releasing hormone neurones. J Neuroendocrinol 22:1-12

141. Rance NE, Bruce TR 1994 Neurokinin B gene expression is increased in the arcuate nucleus of ovariectomized rats. Neuroendocrinology 60:337-345

142. Navarro VM, Castellano JM, McConkey SM, Pineda R, Ruiz-Pino F, Pinilla L, Clifton DK, Tena-Sempere M, Steiner RA 2011 Interactions between kisspeptin and neurokinin B in the control of GnRH secretion in the female rat. Am J Physiol Endocrinol Metab 300:E202-210

143. Kinsey-Jones JS, Grachev P, Li XF, Lin YS, Milligan SR, Lightman SL, O'Byrne KT 2012 The inhibitory effects of neurokinin B on GnRH pulse generator frequency in the female rat. Endocrinology 153:307-315 
144. Billings HJ, Connors JM, Altman SN, Hileman SM, Holaskova I, Lehman MN, McManus CJ, Nestor CC, Jacobs BH, Goodman RL 2010 Neurokinin B acts via the neurokinin-3 receptor in the retrochiasmatic area to stimulate luteinizing hormone secretion in sheep. Endocrinology 151:3836-3846

145. Lee JH, Miele ME, Hicks DJ, Phillips KK, Trent JM, Weissman BE, Welch DR 1996 KiSS1, a novel human malignant melanoma metastasis-suppressor gene. J Natl Cancer Inst 88:17311737

146. Muir AI, Chamberlain L, Elshourbagy NA, Michalovich D, Moore DJ, Calamari A, Szekeres PG, Sarau HM, Chambers JK, Murdock P, Steplewski K, Shabon U, Miller JE, Middleton SE, Darker JG, Larminie CG, Wilson S, Bergsma DJ, Emson P, Faull R, Philpott KL, Harrison DC 2001 AXOR12, a novel human G protein-coupled receptor, activated by the peptide KiSS-1. J Biol Chem 276:28969-28975

147. Clements MK, McDonald TP, Wang R, Xie G, O'Dowd BF, George SR, Austin CP, Liu Q 2001 FMRFamide-related neuropeptides are agonists of the orphan G-protein-coupled receptor GPR54. Biochem Biophys Res Commun 284:1189-1193

148. Kotani M, Detheux M, Vandenbogaerde A, Communi D, Vanderwinden JM, Le Poul E, Brezillon S, Tyldesley R, Suarez-Huerta N, Vandeput F, Blanpain C, Schiffmann SN, Vassart G, Parmentier M 2001 The metastasis suppressor gene KiSS-1 encodes kisspeptins, the natural ligands of the orphan G protein-coupled receptor GPR54. J Biol Chem 276:34631-34636

149. Ohtaki T, Shintani Y, Honda S, Matsumoto H, Hori A, Kanehashi K, Terao Y, Kumano S, Takatsu Y, Masuda Y, Ishibashi Y, Watanabe T, Asada M, Yamada T, Suenaga M, Kitada C, Usuki S, Kurokawa T, Onda H, Nishimura O, Fujino M 2001 Metastasis suppressor gene KiSS-1 encodes peptide ligand of a G-protein-coupled receptor. Nature 411:613-617

150. de Roux N, Genin E, Carel JC, Matsuda F, Chaussain JL, Milgrom E 2003 Hypogonadotropic hypogonadism due to loss of function of the KiSS1-derived peptide receptor GPR54. Proc Natl Acad Sci U S A 100:10972-10976 
151. Seminara SB, Messager S, Chatzidaki EE, Thresher RR, Acierno JS, Jr., Shagoury JK, BoAbbas Y, Kuohung W, Schwinof KM, Hendrick AG, Zahn D, Dixon J, Kaiser UB, Slaugenhaupt SA, Gusella JF, O'Rahilly S, Carlton MB, Crowley WF, Jr., Aparicio SA, Colledge WH 2003 The GPR54 gene as a regulator of puberty. N Engl J Med 349:1614-1627

152. Gottsch ML, Cunningham MJ, Smith JT, Popa SM, Acohido BV, Crowley WF, Seminara S, Clifton DK, Steiner RA 2004 A role for kisspeptins in the regulation of gonadotropin secretion in the mouse. Endocrinology 145:4073-4077

153. Navarro VM, Castellano JM, Fernandez-Fernandez R, Barreiro ML, Roa J, SanchezCriado JE, Aguilar E, Dieguez C, Pinilla L, Tena-Sempere M 2004 Developmental and hormonally regulated messenger ribonucleic acid expression of KiSS-1 and its putative receptor, GPR54, in rat hypothalamus and potent luteinizing hormone-releasing activity of KiSS-1 peptide. Endocrinology 145:4565-4574

154. Arreguin-Arevalo JA, Lents CA, Farmerie TA, Nett TM, Clay CM 2007 KiSS-1 peptide induces release of LH by a direct effect on the hypothalamus of ovariectomized ewes. Anim Reprod Sci 101:265-275

155. Plant TM 2006 The role of KiSS-1 in the regulation of puberty in higher primates. Eur J Endocrinol 155 Suppl 1:S11-16

156. Dhillo WS, Chaudhri OB, Patterson M, Thompson EL, Murphy KG, Badman MK, McGowan BM, Amber V, Patel S, Ghatei MA, Bloom SR 2005 Kisspeptin-54 stimulates the hypothalamic-pituitary gonadal axis in human males. J Clin Endocrinol Metab 90:6609-6615

157. Dhillo WS, Chaudhri OB, Thompson EL, Murphy KG, Patterson M, Ramachandran R, Nijher GK, Amber V, Kokkinos A, Donaldson M, Ghatei MA, Bloom SR 2007 Kisspeptin-54 stimulates gonadotropin release most potently during the preovulatory phase of the menstrual cycle in women. J Clin Endocrinol Metab 92:3958-3966 
158. Han SK, Gottsch ML, Lee KJ, Popa SM, Smith JT, Jakawich SK, Clifton DK, Steiner RA, Herbison AE 2005 Activation of gonadotropin-releasing hormone neurons by kisspeptin as a neuroendocrine switch for the onset of puberty. J Neurosci 25:11349-11356

159. Smith JT, Li Q, Pereira A, Clarke IJ 2009 Kisspeptin neurons in the ovine arcuate nucleus and preoptic area are involved in the preovulatory luteinizing hormone surge. Endocrinology 150:5530-5538

160. Smith JT, Li Q, Yap KS, Shahab M, Roseweir AK, Millar RP, Clarke IJ 2011 Kisspeptin is essential for the full preovulatory LH surge and stimulates GnRH release from the isolated ovine median eminence. Endocrinology 152:1001-1012

161. Lapatto R, Pallais JC, Zhang D, Chan YM, Mahan A, Cerrato F, Le WW, Hoffman GE, Seminara SB 2007 Kiss1-/- mice exhibit more variable hypogonadism than Gpr54-/- mice. Endocrinology 148:4927-4936

162. d'Anglemont de Tassigny X, Fagg LA, Carlton MB, Colledge WH 2008 Kisspeptin can stimulate gonadotropin-releasing hormone $(\mathrm{GnRH})$ release by a direct action at $\mathrm{GnRH}$ nerve terminals. Endocrinology 149:3926-3932

163. Shahab M, Mastronardi C, Seminara SB, Crowley WF, Ojeda SR, Plant TM 2005 Increased hypothalamic GPR54 signaling: a potential mechanism for initiation of puberty in primates. Proc Natl Acad Sci U S A 102:2129-2134

164. Matsui H, Takatsu Y, Kumano S, Matsumoto H, Ohtaki T 2004 Peripheral administration of metastin induces marked gonadotropin release and ovulation in the rat. Biochem Biophys Res Commun 320:383-388

165. Smith JT, Cunningham MJ, Rissman EF, Clifton DK, Steiner RA 2005 Regulation of Kiss1 gene expression in the brain of the female mouse. Endocrinology 146:3686-3692

166. Adachi S, Yamada S, Takatsu Y, Matsui H, Kinoshita M, Takase K, Sugiura H, Ohtaki T, Matsumoto H, Uenoyama Y, Tsukamura H, Inoue K, Maeda K 2007 Involvement of 
anteroventral periventricular metastin/kisspeptin neurons in estrogen positive feedback action on luteinizing hormone release in female rats. J Reprod Dev 53:367-378

167. Clarkson J, Herbison AE 2006 Postnatal development of kisspeptin neurons in mouse hypothalamus; sexual dimorphism and projections to gonadotropin-releasing hormone neurons. Endocrinology 147:5817-5825

168. Franceschini I, Lomet D, Cateau M, Delsol G, Tillet Y, Caraty A 2006 Kisspeptin immunoreactive cells of the ovine preoptic area and arcuate nucleus co-express estrogen receptor alpha. Neurosci Lett 401:225-230

169. Smith JT, Clay CM, Caraty A, Clarke IJ 2007 KiSS-1 messenger ribonucleic acid expression in the hypothalamus of the ewe is regulated by sex steroids and season. Endocrinology 148:11501157

170. Estrada KM, Clay CM, Pompolo S, Smith JT, Clarke IJ 2006 Elevated KiSS-1 expression in the arcuate nucleus prior to the cyclic preovulatory gonadotrophin-releasing hormone/lutenising hormone surge in the ewe suggests a stimulatory role for kisspeptin in oestrogen-positive feedback. J Neuroendocrinol 18:806-809

171. Rometo AM, Krajewski SJ, Voytko ML, Rance NE 2007 Hypertrophy and increased kisspeptin gene expression in the hypothalamic infundibular nucleus of postmenopausal women and ovariectomized monkeys. J Clin Endocrinol Metab 92:2744-2750

172. Herbison AE 2008 Estrogen positive feedback to gonadotropin-releasing hormone (GnRH) neurons in the rodent: the case for the rostral periventricular area of the third ventricle (RP3V). Brain Res Rev 57:277-287

173. Smith JT, Popa SM, Clifton DK, Hoffman GE, Steiner RA 2006 Kiss1 neurons in the forebrain as central processors for generating the preovulatory luteinizing hormone surge. $\mathrm{J}$ Neurosci 26:6687-6694 
174. Dungan HM, Gottsch ML, Zeng H, Gragerov A, Bergmann JE, Vassilatis DK, Clifton DK, Steiner RA 2007 The role of kisspeptin-GPR54 signaling in the tonic regulation and surge release of gonadotropin-releasing hormone/luteinizing hormone. J Neurosci 27:12088-12095

175. Clarkson J, d'Anglemont de Tassigny X, Moreno AS, Colledge WH, Herbison AE 2008 Kisspeptin-GPR54 signaling is essential for preovulatory gonadotropin-releasing hormone neuron activation and the luteinizing hormone surge. J Neurosci 28:8691-8697

176. Kinoshita M, Tsukamura H, Adachi S, Matsui H, Uenoyama Y, Iwata K, Yamada S, Inoue K, Ohtaki T, Matsumoto H, Maeda K 2005 Involvement of central metastin in the regulation of preovulatory luteinizing hormone surge and estrous cyclicity in female rats. Endocrinology 146:4431-4436

177. Caraty A, Fabre-Nys C, Delaleu B, Locatelli A, Bruneau G, Karsch FJ, Herbison A 1998 Evidence that the mediobasal hypothalamus is the primary site of action of estradiol in inducing the preovulatory gonadotropin releasing hormone surge in the ewe. Endocrinology 139:17521760

178. Weick RF 1981 Induction of the luteinizing hormone surge by intrahypothalamic application of estrogen in the rhesus monkey. Biol Reprod 24:415-422

179. Wakabayashi Y, Nakada T, Murata K, Ohkura S, Mogi K, Navarro VM, Clifton DK, Mori Y, Tsukamura H, Maeda K, Steiner RA, Okamura H 2010 Neurokinin B and dynorphin A in kisspeptin neurons of the arcuate nucleus participate in generation of periodic oscillation of neural activity driving pulsatile gonadotropin-releasing hormone secretion in the goat. J Neurosci $30: 3124-3132$

180. Smith JT, Coolen LM, Kriegsfeld LJ, Sari IP, Jaafarzadehshirazi MR, Maltby M, Bateman K, Goodman RL, Tilbrook AJ, Ubuka T, Bentley GE, Clarke IJ, Lehman MN 2008 Variation in kisspeptin and RFamide-related peptide (RFRP) expression and terminal connections to gonadotropin-releasing hormone neurons in the brain: a novel medium for seasonal breeding in the sheep. Endocrinology 149:5770-5782 
181. Hoffman GE, Le WW, Franceschini I, Caraty A, Advis JP 2011 Expression of fos and in vivo median eminence release of LHRH identifies an active role for preoptic area kisspeptin neurons in synchronized surges of LH and LHRH in the ewe. Endocrinology 152:214-222

182. Kauffman AS, Gottsch ML, Roa J, Byquist AC, Crown A, Clifton DK, Hoffman GE, Steiner RA, Tena-Sempere M 2007 Sexual differentiation of Kiss1 gene expression in the brain of the rat. Endocrinology 148:1774-1783

183. Kauffman AS, Navarro VM, Kim J, Clifton D, Steiner RA 2009 Sex Differences in the Regulation of Kiss1/NKB Neurons in Juvenile Mice: Implications for the Timing of Puberty. Am J Physiol Endocrinol Metab 297:E1212-1221

184. Homma T, Sakakibara M, Yamada S, Kinoshita M, Iwata K, Tomikawa J, Kanazawa T, Matsui H, Takatsu Y, Ohtaki T, Matsumoto H, Uenoyama Y, Maeda K, Tsukamura H 2009 Significance of neonatal testicular sex steroids to defeminize anteroventral periventricular kisspeptin neurons and the GnRH/LH surge system in male rats. Biol Reprod 81:1216-1225

185. Semaan SJ, Murray EK, Poling MC, Dhamija S, Forger NG, Kauffman AS 2010 BAXdependent and BAX-independent regulation of Kiss1 neuron development in mice. Endocrinology 151:5807-5817

186. Xu Z, Kaga S, Mochiduki A, Tsubomizu J, Adachi S, Sakai T, Inoue K, Adachi AA 2012 Immunocytochemical localization of kisspeptin neurons in the rat forebrain with special reference to sexual dimorphism and interaction with GnRH neurons. Endocr J 59:161-171

187. Desroziers E, Mikkelsen JD, Duittoz A, Franceschini I 2012 Kisspeptin-immunoreactivity changes in a sex- and hypothalamic-region specific manner across rat postnatal development. J Neuroendocrinol. Epub ahead of print.

188. Redmond JS, Macedo GG, Velez IC, Caraty A, Williams GL, Amstalden M 2011 Kisspeptin activates the hypothalamic-adenohypophyseal-gonadal axis in prepubertal ewe lambs.

Reproduction 141:541-548 
189. Keen KL, Wegner FH, Bloom SR, Ghatei MA, Terasawa E 2008 An increase in kisspeptin-54 release occurs with the pubertal increase in luteinizing hormone-releasing hormone-1 release in the stalk-median eminence of female rhesus monkeys in vivo. Endocrinology 149:4151-4157

190. Gill JC, Wang O, Kakar S, Martinelli E, Carroll RS, Kaiser UB 2010 Reproductive hormonedependent and -independent contributions to developmental changes in kisspeptin in GnRHdeficient hypogonadal mice. PLoS One 5:e11911

191. Mayer C, Boehm U 2011 Female reproductive maturation in the absence of kisspeptin/GPR54 signaling. Nat Neurosci 14:704-710

192. Takase K, Uenoyama Y, Inoue N, Matsui H, Yamada S, Shimizu M, Homma T, Tomikawa J, Kanda S, Matsumoto H, Oka Y, Tsukamura H, Maeda KI 2009 Possible role of oestrogen in pubertal increase of Kiss1/kisspeptin expression in discrete hypothalamic areas of female rats. J Neuroendocrinol 21:527-537

193. Takumi K, Iijima N, Ozawa H 2011 Developmental changes in the expression of kisspeptin mRNA in rat hypothalamus. J Mol Neurosci 43:138-145

194. Ramaswamy S, Seminara SB, Ali B, Ciofi P, Amin NA, Plant TM 2010 Neurokinin B stimulates GnRH release in the male monkey (Macaca mulatta) and is colocalized with kisspeptin in the arcuate nucleus. Endocrinology 151:4494-4503

195. Krajewski SJ, Anderson MJ, Iles-Shih L, Chen KJ, Urbanski HF, Rance NE 2005 Morphologic evidence that neurokinin B modulates gonadotropin-releasing hormone secretion via neurokinin 3 receptors in the rat median eminence. J Comp Neurol 489:372-386

196. Garcia-Galiano D, van Ingen Schenau D, Leon S, Krajnc-Franken MA, Manfredi-Lozano M, Romero-Ruiz A, Navarro VM, Gaytan F, van Noort PI, Pinilla L, Blomenrohr M, TenaSempere M 2012 Kisspeptin Signaling Is Indispensable for Neurokinin B, but not Glutamate, Stimulation of Gonadotropin Secretion in Mice. Endocrinology 153:316-328 


\section{CHAPTER 2}

\section{EVIDENCE OF A ROLE FOR KISSPEPTIN AND NEUROKININ B IN PUBERTY OF \\ FEMALE SHEEP}

Casey C Nestor, Amanda M.S. Briscoe, Shay M. Davis, Miro Valent, Robert L. Goodman, and Stanley M. Hileman

Department of Physiology and Pharmacology, West Virginia University, Morgantown, West Virginia 26506

Running Title: Kisspeptin, NKB and puberty of sheep

This research was originally published in Endocrinology. Nestor CC, Briscoe AMS, Davis SM, Valent M, Goodman RL, Hileman SM. Evidence of a Role for Kisspeptin and Neurokinin B in Puberty of Female Sheep. Endocrinology. 2012 Jun;153(6):2756-65. Copyright 2012, The Endocrine Society 


\begin{abstract}
Puberty onset in female sheep is marked by a decrease in estradiol-negative feedback, allowing for the increase in $\mathrm{GnRH}$ and $\mathrm{LH}$ pulses that heralds the first ovulation. Based on recent genetic studies in humans, two possible neuropeptides that could promote puberty onset are kisspeptin and neurokinin B (NKB). Our first experiment determined whether the NKB agonist, senktide, could stimulate LH secretion in prepubertal ewes. A second study used prepubertal and postpubertal ewes that were intact or ovariectomized (OVX) to test the hypothesis that expression of kisspeptin and NKB in the arcuate nucleus increased postpubertally. For comparison, kisspeptin and NKB expression in age-matched intact, and castrated males were also examined. In experiment 1 , the percentage of ewes showing an LH pulse immediately after injection of senktide $(100 \mu \mathrm{g}, 60 \% ; 500 \mu \mathrm{g}, 100 \%)$ was greater than that for waterinjected controls (experiment 1a, 25\%; experiment 1b, 20\%). In experiment 2, kisspeptin-positive cell numbers in the arcuate nucleus increased after puberty in intact females and were increased by OVX in prepubertal but not postpubertal ewes. Changes in kisspeptin cell numbers were paralleled by changes in kisspeptin-close contacts onto GnRH neurons in the medial preoptic area. NKB cell numbers did not differ significantly between intact prepubertal and postpubertal ewes but increased with OVX in both age groups. NKB fiber immunoreactivity was greater in postpubertal than in prepubertal intact ewes. In agematched males, kisspeptin and NKB cell numbers increased with castration, but decreased with age. These results support the hypothesis that kisspeptin is a gatekeeper to female ovine puberty and raise the possibility that NKB may also play a role, albeit through different means.
\end{abstract}




\section{INTRODUCTION}

Puberty is defined as the time when an individual gains the ability to reproduce. In sheep, achievement of puberty is caused by a decrease in response to estradiol-negative feedback, resulting in an increased

frequency of GnRH, and subsequently LH, pulses (1). In ewes, this increase in LH pulse frequency leads to increased estradiol production that in turn induces the subsequent $\mathrm{GnRH} / \mathrm{LH}$ surge and first ovulation (2). An escape from estradiol-negative feedback and the resultant increase in LH secretion occurs around 25-32 wk of age in ewes (2-4), whereas in rams, this occurs earlier at 10-15wk of age (5). Because GnRH neurons are devoid of estrogen receptor- $\alpha(6,7)$, this neuroendocrine change in sensitivity to estradiol most likely occurs through interneurons that have yet to be identified. Kisspeptin and neurokinin $\mathrm{B}(\mathrm{NKB})$ are two likely neuropeptide candidates that could mediate such interneuronal communication.

Kisspeptin has received considerable attention due to reports that mutations in the kisspeptin receptor, G-protein coupled receptor 54, block pubertal development, and lead to hypogonadotropic hypogonadism in humans $(8,9)$ and mice $(9)$. In subsequent studies across several species, it has been demonstrated that kisspeptin potently stimulates the GnRH/LH axis both before (10-13) and after puberty (14). Moreover, kisspeptin may drive the awakening of reproductive function at puberty because an increase in hypothalamic kisspeptin mRNA abundance is observed after puberty onset in rats (10) and monkeys (15). It has also been shown that kisspeptin mRNA in the hypothalamus increases after ovariectomy (OVX) and is inhibited by steroid replacement $(10,16-18)$. These data are consistent with the possibility that the kisspeptin/GnRH network is intact before puberty but merely inhibited by heightened sensitivity to estradiol negative feedback. One recent study has challenged the hypothesis that kisspeptin is essential for puberty and normal reproduction, because congenital ablation of kisspeptin neurons did not alter puberty or prevent ovulatory cycles in mice (19). However, they also reported that ablation of these neurons at $20 \mathrm{~d}$ of age in prepubertal mice completely abolished ovulatory cycles, suggesting that kisspeptin neurons are essential for reproduction in mice that have developed normally.

More recently, NKB has also been implicated in puberty, because mutations in the gene that encodes for NKB or its receptor, neurokinin 3 receptor (NK3R), block pubertal development in humans 
(20). Interestingly, within the arcuate nucleus (ARC) of the hypothalamus, NKB is found in the same neurons as kisspeptin in mice (21), sheep (22), goats (23), monkeys (24), and humans (25). Much like kisspeptin, ARC NKB mRNA abundance is inhibited by estradiol in adult female mice (26), rats (27), sheep (28), and monkeys (29). However, little information is available on changes in NKB expression across puberty. Although NKB action on the GnRH/LH axis in adult females varies depending on endocrine status $(26,30)$, recent reports in intact adult female rats (26) and sheep (31) show that an NKB receptor agonist, senktide, stimulates LH release. Furthermore, although NKB and senktide increase GnRH/LH secretion before puberty in the male monkey (24), the question still remains as to whether NKB can stimulate LH secretion in prepubertal females. Thus, we hypothesized that kisspeptin and NKB play critical roles in puberty onset in female sheep. This hypothesis leads to three testable predictions. First, we predict that the NKB network is intact before puberty so that senktide will stimulate LH release in prepubertal ewes. Second, because both appear to have stimulatory effects on GnRH/LH, we predict that kisspeptin and NKB expression will be greater in postpubertal than in prepubertal ovary-intact ewes. Third, because puberty is driven by a decreased response to estradiol-negative feedback, we predict that OVX will produce a larger increase in kisspeptin and NKB expression in pre- than postpubertal ewes. Because male sheep show sperm production (3) and a decreased sensitivity to estradiol-negative feedback

(5) at 10-15 wk of age, we used age-matched males that were presumed to be postpubertal as a control for any effect of age that was independent of reproductive function.

\section{MATERIALS AND METHODS}

\section{Animals}

For experiments $1 \mathrm{a}$ and $1 \mathrm{~b}$, prepubertal ewes (5-6 months old) of mixed breeding were housed and studied in an open barn. They received a daily diet of hay and water ad libitum. For experiment 2, a different group of mixed-breed prepubertal female sheep (5-6 months old), postpubertal female sheep ( $>9$ months old), and age-matched males was used during the breeding season (October to February). As mentioned above, all males were presumed to be postpubertal. Sheep were housed in an open barn until 3-14 d before the study, when they were moved indoors. While indoors, they received an alfalfa pellet 
food ration and had open access to water and mineral supplement. Indoor lighting simulated the natural changes in day length. OVX were performed by midlateral laparotomy under gas anesthesia (oxygen + nitric oxide $+3 \%$ halothane) 2 wk before tissue collection. Blood samples were collected via jugular venipuncture into heparinized tubes, and plasma was stored at -20 C. All procedures were approved by the West Virginia University Animal Care and Use Committee and followed National Institutes of Health guidelines for use of animals in research.

\section{Experimental design}

\section{Experiment 1a}

Fourteen ovary-intact prepubertal ewes were weighed and placed into one of three treatment groups: sterile water $(n=4)$, senktide ( $n=5$; Tocris Bioscience, Ellisville, MO), or senktide+acyline $(n=5)$ (National Institute of Child Health and Human Development, Rockville, MD). Acyline (60 $\mu \mathrm{g} / \mathrm{kg}$ ), a GnRH receptor antagonist, was administered im immediately before blood collection. Blood samples were collected at 12-min intervals from ewes for $6 \mathrm{~h}$ with senktide $(100 \mu \mathrm{g})$ or water $(2 \mathrm{ml})$ administered iv at 3 $\mathrm{h}$ of sampling. Mean body weight of ewes injected with water $(36.6 \pm 5.2 \mathrm{~kg})$, senktide $(35.3 \pm 3.4 \mathrm{~kg})$, or senktide + acyline $(36.6 \pm 3.6 \mathrm{~kg})$ did not differ among treatment groups.

\section{Experiment $1 b$}

Based on the results from experiment 1a, a second experiment was performed to examine a higher dose of senktide $(500 \mu \mathrm{g})$. Ten ovary-intact prepubertal ewes from experiment 1a were randomly selected and received either water $(n=5)$ or senktide $(n=5)$. Blood samples were collected every 12 min for $6 \mathrm{~h}$ with injection of water $(3 \mathrm{ml})$ or senktide $(500 \mu \mathrm{g})$ administered iv at $3 \mathrm{~h}$ of sampling.

\section{Experiment 2}

Four groups (five per group) of females (prepubertal intact, prepubertal OVX, postpubertal intact-early follicular, and postpubertal OVX were used for experiment 2. Early follicular (EF) phase ewes were used, because at this time in the ovarian cycle, the dominant steroid is estradiol and as such are similar in steroid environment to prepubertal intact ewes. The ovarian cycles of EF ewes were synchronized by two 
im injections of prostaglandin-F2 $\alpha$ (6 mg/injection; Lutalyse; Henry Schein, Melville,NY) given $3 \mathrm{~h}$ apart and followed $7 \mathrm{~d}$ later by another two im injections given $3 \mathrm{~h}$ apart (32). Killing of ewes in this group occurred $24 \mathrm{~h}$ after the fourth injection of prostaglandin-F2 $\alpha$. Early follicular endocrine status was confirmed by absence of corpora lutea and low plasma progesterone $(0.32 \pm 0.1 \mathrm{ng} / \mathrm{ml})$ on the day of killing. Four groups of age-matched males were either intact (rams) or castrated (wether) (young ram, young wether, older ram, and older wether). Blood samples (3 ml) were taken every $12 \mathrm{~min}$ for $4 \mathrm{~h}$ from all sheep immediately before killing. Tissue was collected as described previously (33). Briefly, all sheep were heparinized (20,000 U) and killed using an iv overdose of sodium pentobarbital (Euthasol; Webster Veterinary, Devens, MA). Heads were removed and perfused with four liters of $4 \%$ paraformaldehyde in $0.1 \mathrm{M}$ phosphate buffer $(\mathrm{PB})(\mathrm{pH}=7.4)$ containing $0.1 \%$ sodium nitrite via the carotid arteries. Blocks of tissue containing the preoptic area (POA) and the hypothalamus were then removed and stored in $4 \%$ paraformaldehyde for $24 \mathrm{~h}$ at $4 \mathrm{C}$ and transferred to $20 \%$ sucrose until sectioned. Frozen coronal sections $(50 \mu \mathrm{m})$ were cut with a freezing microtome and stored in cryopreservative until the time of immunocytochemical staining.

\section{Immunocytochemistry for kisspeptin or NKB}

On $\mathrm{d} 1$, sections were washed $4 \times 5 \mathrm{~min}$ in $0.1 \mathrm{M}$ PBS and stored overnight at $4 \mathrm{C}$. On $\mathrm{d} 2$, sections were washed 4x5 min in PBS then placed in $10 \% \mathrm{H} 2 \mathrm{O} 2$ for 10 min followed by $4 \times 5$ min washes in PBS. Tissue was then incubated for $1 \mathrm{~h}$ with $0.4 \%$ Triton X (Sigma-Aldrich, St. Louis, MO) in 20\% normal goat serum for kisspeptin or $4 \%$ normal goat serum for NKB, both made in PBS. Kisspeptin and NKB neurons were identified using primary antibodies for kisspeptin (gift from A. Caraty) and NKB (Peninsula Laboratories, San Carlos, CA) that have been validated for use in sheep $(22,33)$. Five to six sections of the middle to caudal ARC from each animal were incubated with 1:50,000 kisspeptin antiserum raised in rabbit or 1:100,000 NKB antiserum raised in rabbit for $18 \mathrm{~h}$ at room temperature; one to two sections from the POA were also analyzed immunocytochemically for kisspeptin (1:50,000). On d 3, biotinylated goat antirabbit antibody (Vector Laboratories, Burlingame, CA) at 1:500 and Vectastain ABC-elite (Vector Laboratories) at 1:500 were applied sequentially for $1 \mathrm{~h}$ each with $4 \times 5$ min washes of PBS 
between incubations. Sections were then placed in a 3,3'-diaminobenzidine tetrahydrochloride (DAB) solution (10mg of DAB; Sigma-Aldrich) in $50 \mathrm{ml}$ of $\mathrm{PB}$ with $20 \mu \mathrm{l}$ of $30 \% \mathrm{H}_{2} \mathrm{O}_{2}$ added just before incubation for $10 \mathrm{~min}$. After $3 \times 5$ min washes in PB, sections were mounted on Superfrost/Plus microscope slides (Fisher Scientific, Pittsburgh, PA), dehydrated using a series of increasing alcohol baths, and coverslipped using DPX Mounting Medium (Electron Microscopy Sciences, Hatfield, PA).

\section{Dual immunocytochemistry for kisspeptin and GnRH}

One section from the medial POA, which included the organum vasculosum of the lamina terminalis for each female ewe used in experiment 2 was chosen to analyze kisspeptin-positive close contacts on GnRH neurons. Kisspeptin staining was the same as described above through the incubation with ABC solution, except that the kisspeptin antibody was used at a 1:75,000 dilution. After the 1-h incubation with ABC solution, tissue was incubated for 30 min with Alexa Fluor 555 streptavidin (Invitrogen, Carlsbad, CA) at 1:300 in PBS followed by 4x5 min in PBS; sections and reagents with fluorescent substrates were covered to prevent light exposure from here on. Sections were incubated in $0.4 \%$ Triton X in PBS containing 4\% normal goat serum for $1 \mathrm{~h}$ followed by overnight incubation in PBS with $4 \%$ normal goat serum containing mouse anti-GnRH antibody (1:3000, lot no. 3; Sternberger Monoclonal, Inc., Lutherville, MD) at room temperature. On d 4, sections were washed 4x5 min in PBS and then incubated in Alexa Fluor 488 conjugated goat antimouse antibody (Invitrogen) at 1:200 in PBS for 30 min. Tissue was washed $4 \times 5$ min in $\mathrm{PB}$, then coverslipped using gelvatol and stored in the dark at $4 \mathrm{C}$.

\section{Data analysis}

\section{Immunocytochemistry}

For single antigen staining, cell bodies, identified by cells containing a brown cytoplasmic staining, were counted manually using an Olympus AZ70 transmitted light microscope (Center Valley, PA) from four (NKB) or five (kisspeptin) sections of middle to caudal ARC, and mean cell numbers/section for each group were averaged, because there was no difference in cell numbers between the middle and caudal 
ARC. NKB fiber immunoreactivity was assessed for one representative caudal ARC section from each intact and OVX ewe by three individuals blinded to treatment group. Each individual ranked fiber staining from zero to four, with zero being minimal fiber immunoreactivity and four being the most dense. For kisspeptin/GnRH staining, kisspeptin-positive close contacts (red) on GnRH neurons (green; 9-11 neurons per animal) were acquired from a three-dimensional (3D) reconstruction using a Zeiss LSM 510 laser scanning confocal (Hornwood, NY) on a Zeiss Axio Image Z1 upright microscope with a Plan Apochromat $63 \mathrm{x} / 1.4$ oil objective. 3D images presented here were taken at 1-_m increments through each GnRH cell, the image stack was deconvoluted using Auto Quant X2.2 (Media Cybernetics, Bethesda, MD), and 3D rendering was performed using NIS Elements AR 3.2 (Melville, NY).

\section{Assays}

LH concentrations were measured in duplicate with a radioimmunoassay (RIA) using 100-200 $\mu$ of plasma and reagents provided by the National Hormone and Peptide Program (Torrance, CA) as previously described (34). LH assay sensitivity averaged $0.07 \mathrm{ng} / \mathrm{ml}$ (NIH S24) with intra- and interassay coefficients of variation being 12.7 and $18.2 \%$, respectively. Progesterone concentrations were measured in duplicate $150 \mu \mathrm{l}$ aliquots of two plasma samples from each EF ewe using a RIA that has been validated for use in sheep (35); assay sensitivity was $0.01 \mathrm{ng} / \mathrm{ml}$.

\section{Statistics}

Pulses were identified using previously described criteria (36). For experiment 1 , the comparison of percentages of animals that displayed an LH pulse within 24 min (two samples) after iv administration of water or senktide was analyzed using the $\chi^{2}$ test. Also for experiment 1 , mean LH for two samples immediately before iv injection was averaged and compared with the mean of two samples taken immediately after iv injection using a paired $t$-test. For experiment 2, mean LH, LH pulse amplitude, mean number of cell bodies between groups within sex, and number of kisspeptin-positive close contacts per GnRH neuron were analyzed using two-way ANOVA. The percentage of GnRH neurons contacted by kisspeptin was transformed using natural log and then analyzed using a two-way ANOVA. The three rankings of NKB fiber immunoreactivity were averaged, and differences between prepubertal 
and postpubertal intact ewes or prepubertal and postpubertal OVX ewes were analyzed using the nonparametric permutation test for two independent samples. LH pulse frequency was analyzed using the Mann-Whitney $U$ test. Differences were considered to be significant at $P<0.05$.

\section{RESULTS}

\section{Experiment 1a. Can senktide, an NK3R agonist, stimulate LH secretion in prepubertal lambs?}

Representative LH pulse profiles from prepubertal ewes receiving an iv injection of water (open circles) or $100 \mu \mathrm{g}$ of senktide (closed circles) are illustrated in Fig. 1A. Senktide had no significant effect on pulse frequency (preinjection, $1.4 \pm 0.3$ pulses/3 h vs. postinjection, $1.8 \pm 0.4$ pulses $/ 3 \mathrm{~h}$ ). Because it was possible that the effects of the senktide were immediate but transitory, we analyzed the percentage of animals that responded with an LH pulse within 24 min of injection and found a significant difference between senktide and water-injected animals. Senktide stimulated an LH pulse in three of five (60\%) prepubertal ewes within $24 \mathrm{~min}$, whereas only one of four (25\%) prepubertal ewes receiving water displayed an $\mathrm{LH}$ pulse. Mean LH 24 min after injection of water $(5.14 \pm 2.58 \mathrm{ng} / \mathrm{ml})$ did not significantly differ from mean values $24 \mathrm{~min}$ before injection $(2.63 \pm 1.45 \mathrm{ng} / \mathrm{ml})$ but there was a strong tendency $(P=0.052)$ (Fig. 1B) for mean $\mathrm{LH}$ to be greater $24 \mathrm{~min}$ after $100 \mu \mathrm{g}$ of senktide $(6.51 \pm 1.93 \mathrm{ng} / \mathrm{ml})$ than $24 \mathrm{~min}$ before senktide $(1.18 \pm 0.21 \mathrm{ng} / \mathrm{ml})$. None of the five prepubertal ewes that received the GnRH receptor antagonist, acyline, just before blood collection showed an LH pulse in response to $100 \mu \mathrm{g}$ of senktide (Appendix: Supplemental Fig. 1).

\section{Experiment 1b}

Given the partial response in experiment 1a, we next tested the response to a higher dose $(500 \mu \mathrm{g})$ of senktide. Representative LH pulse profiles from prepubertal ewes receiving an iv injection of either water (open circles) or $500 \mu \mathrm{g}$ of senktide (closed circles) is illustrated in Fig. 1C. This dose of senktide stimulated an LH pulse in all five (100\%) prepubertal ewes, whereas only one of five (20\%) prepubertal ewes receiving an injection of water displayed an LH pulse within 24 min of injection, a difference in response that was significant. Furthermore, mean LH for 24 min after injection of $500 \mu \mathrm{g}$ of senktide $(6.22 \pm 0.68 \mathrm{ng} / \mathrm{ml})$ was significantly greater than mean values for $24 \mathrm{~min}$ before injection $(3.05 \pm 1.08$ 
$\mathrm{ng} / \mathrm{ml}$ ), whereas vehicle had no significant effect (preinjection, $3.56 \pm 0.44 \mathrm{ng} / \mathrm{ml}$; postinjection, $4.36 \pm$ $1.27 \mathrm{ng} / \mathrm{ml}$ ) on mean LH concentrations (Fig. 1D).

\section{Experiment 2. Does expression of kisspeptin or NKB protein increase with puberty and/or gonadectomy (GNDX)?}

Mean LH (Fig. 2A) and LH pulse amplitude (Fig. 2C) were significantly increased after GNDX in both ewes and rams at all ages, but there was no effect of age and no age by GNDX interaction. LH pulse frequency (Fig. 2B) was also significantly increased after GNDX in prepubertal females and in both young and older males, but not in postpubertal females. Analysis of kisspeptin cell numbers in the ARC indicated that the number of kisspeptin-positive cells was higher after puberty ( $358 \pm 77$ per ewe) than before puberty (204 \pm 81 per ewe) in ovary-intact females (Fig. 3, A, B, and E). Furthermore, kisspeptinpositive cell numbers significantly increased after OVX (Fig. 3E) in prepubertal ewes ( $447 \pm 88$ per ewe), but not in postpu- bertal ewes $(473 \pm 151$ per ewe). In males, there was a significant effect of GNDX, because kisspeptin cell numbers were higher in castrated males compared with intact rams (Fig. 3E and Appendix: Supplemental Fig. 2). There also was a significant effect of age, indicating that cell numbers were lower in both intact and castrated older males compared with younger males (Fig. 3E) but no interaction of age and GNDX. Kisspeptin cell numbers strongly tended $(P=0.068)$ to be greater in postpubertal OVX ewes $(473 \pm 96$ per ewe) than age-matched GNDX males $(138 \pm 105$ per wether) but were not different between prepubertal OVX ewes (447 \pm 89 per ewe) and age-matched GNDX males $(486 \pm 96$ per wether).

To determine whether puberty-related changes in kisspeptin cell numbers altered kisspeptin synaptic input onto GnRH neurons, we examined kisspeptin-positive close contacts on GnRH neurons in the medial POA in females (Fig. 4). The change in the percentage of GnRH neurons displaying kisspeptin-positive close contacts (Fig. 4C) paralleled the changes that we observed in kisspeptin cell numbers. Specifically, a significantly higher percentage of GnRH neurons received close contacts after puberty in ovary-intact females (prepubertal, $34.9 \pm 6.5 \%$; postpubertal, $71.7 \pm 1.8 \%$ ). This percentage significantly increased after OVX in prepubertal ewes $(64.9 \pm 6.6 \%)$, but not in postpubertal ewes $(61.8 \pm$ 
2.7\%). However, the number of kisspeptin-positive close contacts per GnRH neuron (Fig. 4D) did not differ significantly among groups. POA sections containing GnRH neurons were also examined at lower magnification to quantify kisspeptin-containing cell bodies in this region with immunofluorescence. In contrast to previous analysis of tissue from adults (22), only one kisspeptinpositive cell body was observed in all sections from these young females. Therefore, we examined kisspeptin in a wider range of POA sections from these same females using single-label immunocytochemistry. Even using DAB as a chromogen, kisspeptin immunoreactivity in the POA was light and inconsistent across ewes (Appendix: Supplemental Fig. 3), making accurate identification and counting of cells impossible. Therefore, we did not quantify kisspeptin cells in the POA for this study. NKB cell numbers were examined only in the ARC, because NKB-containing neurons are largely limited to this nucleus in the ovine hypothalamus (37). The number of NKB cells (Fig. 5) significantly increased after OVX in both prepubertal and postpubertal females (from $188 \pm 75$ to $347 \pm 37$ per ewe and from $158 \pm 46$ to $357 \pm 56$ per ewe, respectively) (Fig. 5E). However, in contrast to kisspeptin, there was no change in the number of NKB containing cells between prepubertal (188 \pm 75 per ewe) and postpubertal $(158+46$ per ewe) ovary-intact ewes (Fig. 5E). While counting cell numbers, we noted obvious variation among animals in NKB fiber density. After further assessment, we found that NKB fiber immunoreactivitywas significantly greater in EF ewes (rank of $2.7 \pm 0.8$ ) compared with prepubertal intact ewes (rank of 1.2 \pm 0.4 ) with no significant difference in fiber density between prepubertal (rank of $1.3 \pm 0.8$ ) and postpubertal OVX ewes (rank of $2.8 \pm 0.6$ ). In males, GNDX significantly increased NKB cell numbers at both ages (Fig. 5E). There was an interaction of age and GNDX on NKB-positive cell numbers, likely due to the larger absolute decrease in NKB cell numbers observed in GNDX males $(\delta$,143 per wether) with age compared with intact males ( $\delta,-73$ per ram) (Fig. 5E and Appendix:

Supplemental Fig. 4). However, the percent decrease with age appeared to be greater for the intact (89\% decrease) than GNDX (60\% decrease) males. NKB cell numbers were significantly greater in postpubertal OVX ewes $(357 \pm 37$ per ewe) than age-matched GNDX males ( $108 \pm 45$ per wether $)$, but 
were not different between prepubertal OVX ewes $(347 \pm 37$ per ewe) and age-matched GNDX males $(272 \pm 37$ per wether). In addition, NKB cell numbers decreased with age in GNDX males.

\section{DISCUSSION}

The data herein provide evidence of a role for kisspeptin and NKB in puberty of female sheep. Our observation that kisspeptin cell numbers within the ARC increase after puberty in females, but not in age-matched postpubertal males, is consistent with an important role for this peptide in the onset of puberty. Furthermore, we show an increase in kisspeptin- positive close contacts on GnRH neurons in the medial POA of ewes that closely mirrored the increase in ARC kisspeptin cell numbers after puberty. The stimulatory effect of senktide on LH secretion and the OVX induced increase in NKB cell number in prepubertal ewes indicate a possible role for NKB in estradiol-negative feedback before puberty. Although there was not an increase in NKB-positive cell bodies after puberty, the increased density of NKB immunoreactive fibers leads us to suggest that NKB expression may also be increased.

It is generally thought that kisspeptin input to GnRH neurons is a limiting factor for induction of the onset of puberty, but whether it is the kisspeptin neurons in the ARC or more rostral areas [anteroventral periventricular nucleus (AVPV) in rodents, POA in other species, (38)] that are involved remains controversial. In female rats, postpubertal increases in kisspeptin mRNA $(39,40)$ and protein (39) occur in both the AVPV and ARC. In female mice, kisspeptinmRNAand protein increase in the AVPV (41-44), but changes in ARC kisspeptin mRNA expression are inconsistent (41, 42), leading to the hypothesis that AVPV kisspeptin drives puberty onset in mice (43). However, it was recently reported (19) that ablation of ARC kisspeptin neurons at postnatal d 20 disrupted ovarian function in mice, a result consistent with ARC kisspeptin neurons playing a critical role in puberty. The authors argued that these lesions were ARC specific because the time of kisspeptin neuronal ablation occurred before appearance of kisspeptin in the AVPV, but provided no immunocytochemical staining of the AVPV or ARC to support the specificity of the lesion. In estradiol-treated OVX ewes, kisspeptin mRNA increased with age in the POA, but not in the ARC, during pubertal development (45). In the present study, we observed that kisspeptin cell numbers in the ARC are greater in postpubertal than prepubertal ewes, whereas kisspeptin 
immunoreactivity in the POA was insufficient to accurately quantify cell numbers. Comparison of these two studies in ewes suggests a possible disconnect between mRNA and protein, as has been observed in pubertal mice (41). Notably, both studies observed a positive association between ARC kisspeptin expression and LH pulse frequency during pubertal development, a finding consistent with the hypothesis that an increase in ARC kisspeptin is required for pubertal progression in the ewe.

Interestingly, we also observed that kisspeptin-positive close contacts on GnRH neurons increase after OVX in prepubertal ewes and are significantly greater in postpubertal compared with prepubertal ovary-intact lambs. A similar increase in kisspeptin inputs onto GnRH neurons after puberty has been observed in mice (43), but the origin of this input remains unclear. The coinciding changes in kisspeptin content within the ARC with the changes in kisspeptin-containing close contacts on GnRH neurons strongly suggests that kisspeptin cells in the ARC, and not the POA, are the source of this input in ewes. A similar correlation of kisspeptin in the ARC and kisspeptin input onto GnRH neurons was seen between breeding and non-breeding seasons in the adult ewe (46). Although it has been reported that only $1-2 \%$ of kisspeptin contacts onto GnRH neurons originate from the ARC (47), this tract tracing study used a small injection volume of Fluoro-Gold, which may have covered only a relatively small area of the POA, in which GnRH neurons reside. A different anatomical approach was used to show that approximately $50-70 \%$ of GnRH neurons receive close contacts containing both kisspeptin and dynorphin (48), a percentage consistent with that observed in OVX or intact postpubertal ewes from our study. Because the only set of neurons known to contain both kisspeptin and dynorphin in the hypothalamus are the subset of neurons in the ARC that also contain $\operatorname{NKB}(22,38)$, we conclude that kisspeptin input from within the ARC is primarily responsible for the increased input to GnRH neurons during puberty in the ewe.

Because puberty onset in the ewe is marked by an increase in $\mathrm{GnRH} / \mathrm{LH}$ secretion due to a decrease in estradiol-negative feedback (1), we predicted that a pubertal increase in kisspeptin production within the ARC would occur in response to a lessening of steroid-negative feedback. The increase in kisspeptin expression after OVX of prepubertal, but not postpubertal, ewes is consistent with this 
hypothesis. It should also be noted that the proposed negative feedback inhibition of kisspeptin expression in the ARC before puberty is consistent with findings that estradiol exerts negative feedback effects on kisspeptin mRNA and protein expression in the adult ovine ARC during anestrus (46). The lack of an increase after OVX in our postpubertal ewes contrasts with previous data in ewes using in situ hybridization (17). One explanation for these differences is that by using immunocytochemistry, we are unable to detect any increase in kisspeptin production within cells that were already producing immunoreactive peptide. However, this apparent contradiction most likely reflects differences in cell numbers between ovary intact groups in the luteal (17) and follicular (this study) phases, because the number of kisspeptin cells in the ARC increases after luteolysis in the ewe (49).

As previously mentioned, kisspeptin cells in the ovine ARC of the hypothalamus also contain NKB (22). In humans, NKB and NK3R are crucial for puberty onset (20). We report here that a peripheral injection of senktide, an NK3R agonist, stimulated LH release in the prepubertal ewe. Because acyline abolished LH secretion and blocked any effect of senktide, we suggest that the effect of senktide occurs at the level of the hypothalamus to cause GnRH release. These data fit well with recent reports that intact adult ewes (31) and prepubertal male primates (24) both respond to senktide administration with an increase in LH release. In OVX goats, NKB stimulates multiunit activity within the ARC but decreases LH secretion; no effects of senktide were seen in OVX ewes (31). In rodents, both stimulatory (26, 50, 51) and inhibitory $(30,50)$ effects of senktide on LH have been observed, a response that seems largely dependent upon steroid milieu.

Unlike kisspeptin, NKB cell numbers did not increase postpubertally in intact ewes, which is similar to a previous report in mice using in situ hybridization to identify these cells (52). It is possible that NKB cell numbers increased in prepubertal ewes before the time analyzed in this study. If so, this increase did not lead to stimulation of LH release or induction of puberty, perhaps due to insufficient kisspeptin. This would be consistent with the hypothesis that NKB acts via kisspeptin to stimulate GnRH/LH release $(21,23,53,54)$ and with the idea that although NKB may be necessary, kisspeptin is the gatekeeper to puberty onset. Our data also indicate that NKB and kisspeptin may be differentially 
regulated in the same cells, as has been observed previously within kisspeptin/NKB/dynorphin neurons (55) as well as other neurons in the ARC that express more than one neuropeptide (56). Although cell numbers were unaltered, NKB fiber density did increase in EF ewes compared with prepubertal intact ewes. Increases in kisspeptin immunoreactive fibers within the ARC during the pubertal transition have been reported in rodents $(43,44)$, but this is the first evidence for similar increases in NKB immunoreactive fibers. One simple explanation for this observation is that parallel increases in synthesis and transport of NKB occur in these neurons. Interestingly, NKB cell numbers did increase after GNDX in both prepubertal and postpubertal ewes, suggesting that estradiol was limiting NKB expression at both ages. This is consistent with the report where estradiol failed to suppress NKB gene expression in estrogen receptor-_ knockout mice (57), because NKB neurons contain ER $\alpha$ (53).

Sex differences in kisspeptin expression in sheep (55) and humans (25) and NKB expression in sheep $(35,55)$ have been reported to exist within the ARC. Sex differences in NKB expression are clearly due to organizational effects of testosterone during prenatal development $(37,55)$, but whether the sexual dimorphism in kisspeptin content is due to organizational or activational effects of gonadal steroids remains unclear (55). The inclusion of OVX ewes and castrated males of a similar age in our study allows us to address this question. Our data show that in the ovine ARC, kisspeptin cell numbers strongly tended to be, and NKB cell numbers were, significantly greater in postpubertal OVX ewes compared with castrated males of a similar age. Because these differences cannot be due to activational actions of gonadal steroids, we conclude that sex differences in both kisspeptin and NKB are caused by organizational actions of steroids. Interestingly, prepubertal OVX ewes did not differ from castrated males of a similar age in kisspeptin and NKB cell numbers. Thus, the organizational effects of steroids on these neurons in sheep may only become evident as they reach adulthood and appear largely to be due to a loss of expression in older males (Figs. 3 and 5).

In conclusion, the data here support the hypothesis that kisspeptin is a gatekeeper to puberty onset in the ewe and raise the possibility that increases in NKB may also contribute to this process. 
Furthermore, we suggest the increase in kisspeptin input is reflected in the medial POA at the GnRH cell bodies. These data also clearly demonstrate that NKB expression is under the control of steroid negative feedback in both prepubertal and postpubertal ewes and support the proposed stimulatory role for this neuropeptide in the ewe.

\section{ACKNOLEDGEMENTS}

We thank Heather Bungard and Jennifer Lydon (West Virginia University Food Animal Research Facility) for care of animals, Paul Harton for his technical assistance in sectioning tissue, Dr. John Connors for statistical analysis, and Dr. Alain Caraty for the kisspeptin antibody. We also thank Dr. Al

Parlow and the National Hormone and Peptide Program for reagents used to measure LH and the Contraception and Reproductive Health Branch of the National Institute of Child Health and Human

Development (Rockville, MD) for the gift of acyline. The work was in-part supported by grant P20RR16477 from the National Center for Research Resources awarded to the West Virginia IDeA Network for Biomedical Research Excellence. Imaging experiments and image analysis were performed in the West Virginia University Microscope Imaging Facility, which has been supported by the Mary Babb Randolph Cancer Center and NIH grants P20 RR016440 and P30 RR032138. 


\section{REFERENCE LIST}

1. Foster DL and Jackson LM 2006 Puberty in the sheep. In: Neill JD, ed. Knobil and Neill's Physiology of Reproduction, $3^{\text {rd }}$ edition, Vol. 2. Amsterdam: Elsevier; pp. 2127-2176.

2. Huffman LJ, Inskeep EK, Goodman RL 1987 Changes in episodic luteinizing hormone secretion leading to puberty in the lamb. Biol Reprod 37:755-761

3. Claypool LE, Foster DL 1990 Sexual differentiation of the mechanism controlling pulsatile secretion of luteinizing hormone contributes to sexual differences in the timing of puberty in sheep. Endocrinology 126:1206-1215

4. Foster DL, Karsch FJ, Olster DH, Ryan KD, Yellon SM 1986 Determinants of puberty in a seasonal breeder. Recent Prog Horm Res 42:331-384

5. Olster DH, Foster DL 1986 Control of gonadotropin secretion in the male during puberty: a decrease in response to steroid inhibitory feedback in the absence of an increase in steroidindependent drive in the sheep. Endocrinology 118:2225-2234

6. Herbison AE, Robinson JE, Skinner DC 1993 Distribution of estrogen receptorimmunoreactive cells in the preoptic area of the ewe: co-localization with glutamic acid decarboxylase but not luteinizing hormone-releasing hormone. Neuroendocrinology 57:751-759

7. Lehman MN, Karsch FJ 1993 Do gonadotropin-releasing hormone, tyrosine hydroxylase-, and beta-endorphin-immunoreactive neurons contain estrogen receptors? A double-label immunocytochemical study in the Suffolk ewe. Endocrinology 133:887-895

8. de Roux N, Genin E, Carel JC, Matsuda F, Chaussain JL, Milgrom E 2003 Hypogonadotropic hypogonadism due to loss of function of the KiSS1-derived peptide receptor GPR54. Proc Natl Acad Sci U S A 100:10972-10976

9. Seminara SB, Messager S, Chatzidaki EE, Thresher RR, Acierno JS, Jr., Shagoury JK, BoAbbas Y, Kuohung W, Schwinof KM, Hendrick AG, Zahn D, Dixon J, Kaiser UB, Slaugenhaupt SA, Gusella JF, O'Rahilly S, Carlton MB, Crowley WF, Jr., Aparicio SA, Colledge WH 2003 The GPR54 gene as a regulator of puberty. N Engl J Med 349:1614-1627 
10. Navarro VM, Castellano JM, Fernandez-Fernandez R, Barreiro ML, Roa J, SanchezCriado JE, Aguilar E, Dieguez C, Pinilla L, Tena-Sempere M 2004 Developmental and hormonally regulated messenger ribonucleic acid expression of KiSS-1 and its putative receptor, GPR54, in rat hypothalamus and potent luteinizing hormone-releasing activity of KiSS-1 peptide. Endocrinology 145:4565-4574

11. Plant TM, Ramaswamy S, Dipietro MJ 2006 Repetitive activation of hypothalamic G proteincoupled receptor 54 with intravenous pulses of kisspeptin in the juvenile monkey (Macaca mulatta) elicits a sustained train of gonadotropin-releasing hormone discharges. Endocrinology $147: 1007-1013$

12. Keen KL, Wegner FH, Bloom SR, Ghatei MA, Terasawa E 2008 An increase in kisspeptin-54 release occurs with the pubertal increase in luteinizing hormone-releasing hormone-1 release in the stalk-median eminence of female rhesus monkeys in vivo. Endocrinology 149:4151-4157

13. Redmond JS, Macedo GG, Velez IC, Caraty A, Williams GL, Amstalden M 2011 Kisspeptin activates the hypothalamic-adenohypophyseal-gonadal axis in prepubertal ewe lambs. Reproduction 141:541-548

14. Roseweir AK, Millar RP 2009 The role of kisspeptin in the control of gonadotrophin secretion. Hum Reprod Update 15:203-212

15. Shahab M, Mastronardi C, Seminara SB, Crowley WF, Ojeda SR, Plant TM 2005 Increased hypothalamic GPR54 signaling: a potential mechanism for initiation of puberty in primates. Proc Natl Acad Sci U S A 102:2129-2134

16. Smith JT, Cunningham MJ, Rissman EF, Clifton DK, Steiner RA 2005 Regulation of Kiss1 gene expression in the brain of the female mouse. Endocrinology 146:3686-3692

17. Smith JT, Clay CM, Caraty A, Clarke IJ 2007 KiSS-1 messenger ribonucleic acid expression in the hypothalamus of the ewe is regulated by sex steroids and season. Endocrinology 148:11501157 
18. Rometo AM, Krajewski SJ, Voytko ML, Rance NE 2007 Hypertrophy and increased kisspeptin gene expression in the hypothalamic infundibular nucleus of postmenopausal women and ovariectomized monkeys. J Clin Endocrinol Metab 92:2744-2750

19. Mayer C, Boehm U 2011 Female reproductive maturation in the absence of kisspeptin/GPR54 signaling. Nat Neurosci 14:704-710.

20. Topaloglu AK, Reimann F, Guclu M, Yalin AS, Kotan LD, Porter KM, Serin A, Mungan NO, Cook JR, Ozbek MN, Imamoglu S, Akalin NS, Yuksel B, O'Rahilly S, Semple RK 2009 TAC3 and TACR3 mutations in familial hypogonadotropic hypogonadism reveal a key role for Neurokinin B in the central control of reproduction. Nat Genet 41:354-358

21. Navarro VM, Gottsch ML, Chavkin C, Okamura H, Clifton DK, Steiner RA 2009 Regulation of gonadotropin-releasing hormone secretion by kisspeptin/dynorphin/neurokinin B neurons in the arcuate nucleus of the mouse. J Neurosci 29:11859-11866

22. Goodman RL, Lehman MN, Smith JT, Coolen LM, de Oliveira CV, Jafarzadehshirazi MR, Pereira A, Iqbal J, Caraty A, Ciofi P, Clarke IJ 2007 Kisspeptin neurons in the arcuate nucleus of the ewe express both dynorphin A and neurokinin B. Endocrinology 148:5752-5760

23. Wakabayashi Y, Nakada T, Murata K, Ohkura S, Mogi K, Navarro VM, Clifton DK, Mori Y, Tsukamura H, Maeda K, Steiner RA, Okamura H 2010 Neurokinin B and dynorphin A in kisspeptin neurons of the arcuate nucleus participate in generation of periodic oscillation of neural activity driving pulsatile gonadotropin-releasing hormone secretion in the goat. J Neurosci 30:3124-3132.22.

24. Ramaswamy S, Seminara SB, Ali B, Ciofi P, Amin NA, Plant TM 2010 Neurokinin B stimulates GnRH release in the male monkey (Macaca mulatta) and is colocalized with kisspeptin in the arcuate nucleus. Endocrinology 151:4494-4503

25. Hrabovszky E, Ciofi P, Vida B, Horvath MC, Keller E, Caraty A, Bloom SR, Ghatei MA, Dhillo WS, Liposits Z, Kallo I 2010 The kisspeptin system of the human hypothalamus: sexual 
dimorphism and relationship with gonadotropin-releasing hormone and neurokinin B neurons.

Eur J Neurosci 31:1984-1998

26. Navarro VM, Castellano JM, McConkey SM, Pineda R, Ruiz-Pino F, Pinilla L, Clifton DK, Tena-Sempere M, Steiner RA 2011 Interactions between kisspeptin and neurokinin B in the control of GnRH secretion in the female rat. Am J Physiol Endocrinol Metab 300:E202-210

27. Rance NE, Bruce TR 1994 Neurokinin B gene expression is increased in the arcuate nucleus of ovariectomized rats. Neuroendocrinology 60:337-345

28. Pillon D, Caraty A, Fabre-Nys C, Bruneau G 2003 Short-term effect of oestradiol on neurokinin B mRNA expression in the infundibular nucleus of ewes. J Neuroendocrinol 15:749753

29. Abel TW, Voytko ML, Rance NE 1999 The effects of hormone replacement therapy on hypothalamic neuropeptide gene expression in a primate model of menopause. J Clin Endocrinol Metab 84:2111-2118

30. Sandoval-Guzman T, Rance NE 2004 Central injection of senktide, an NK3 receptor agonist, or neuropeptide Y inhibits LH secretion and induces different patterns of Fos expression in the rat hypothalamus. Brain Res 1026:307-312

31. Billings HJ, Connors JM, Altman SN, Hileman SM, Holaskova I, Lehman MN, McManus CJ, Nestor CC, Jacobs BH, Goodman RL 2010 Neurokinin B acts via the neurokinin-3 receptor in the retrochiasmatic area to stimulate luteinizing hormone secretion in sheep. Endocrinology 151:3836-3846

32. Deaver DR, Stilley NJ, Dailey RA, Inskeep EK, Lewis PE 1986 Concentrations of ovarian and pituitary hormones following prostaglandin F2 alpha-induced luteal regression in ewes varies with day of the estrous cycle at treatment. J Anim Sci 62:422-427

33. Foradori CD, Amstalden M, Goodman RL, Lehman MN 2006 Colocalisation of dynorphin a and neurokinin B immunoreactivity in the arcuate nucleus and median eminence of the sheep. $\mathrm{J}$ Neuroendocrinol 18:534-541 
34. Whisnant CS, Goodman RL 1988 Effects of an opioid antagonist on pulsatile luteinizing hormone secretion in the ewe vary with changes in steroid negative feedback. Biol Reprod 39:1032-1038

35. Goodman RL, Coolen LM, Anderson GM, Hardy SL, Valent M, Connors JM, Fitzgerald ME, Lehman MN 2004 Evidence that dynorphin plays a major role in mediating progesterone negative feedback on gonadotropin-releasing hormone neurons in sheep. Endocrinology $145: 2959-2967$

36. Goodman RL, Karsch FJ 1980 Pulsatile secretion of luteinizing hormone: differential suppression by ovarian steroids. Endocrinology 107:1286-1290

37. Goubillon ML, Forsdike RA, Robinson JE, Ciofi P, Caraty A, Herbison AE 2000 Identification of neurokinin B-expressing neurons as an highly estrogen-receptive, sexually dimorphic cell group in the ovine arcuate nucleus. Endocrinology 141:4218-4225

38. Lehman MN, Merkley CM, Coolen LM, Goodman RL 2010 Anatomy of the kisspeptin neural network in mammals. Brain Res 1364:90-102

39. Takase K, Uenoyama Y, Inoue N, Matsui H, Yamada S, Shimizu M, Homma T, Tomikawa J, Kanda S, Matsumoto H, Oka Y, Tsukamura H, Maeda KI 2009 Possible role of oestrogen in pubertal increase of Kiss1/kisspeptin expression in discrete hypothalamic areas of female rats. J Neuroendocrinol 21:527-537

40. Takumi K, Iijima N, Ozawa H 2011 Developmental changes in the expression of kisspeptin mRNA in rat hypothalamus. J Mol Neurosci 43:138-145

41. Gill JC, Wang O, Kakar S, Martinelli E, Carroll RS, Kaiser UB 2010 Reproductive hormonedependent and -independent contributions to developmental changes in kisspeptin in GnRHdeficient hypogonadal mice. PLoS One 5:e11911

42. Han SK, Gottsch ML, Lee KJ, Popa SM, Smith JT, Jakawich SK, Clifton DK, Steiner RA, Herbison AE 2005 Activation of gonadotropin-releasing hormone neurons by kisspeptin as a neuroendocrine switch for the onset of puberty. J Neurosci 25:11349-11356 
43. Clarkson J, Herbison AE 2006 Postnatal development of kisspeptin neurons in mouse hypothalamus; sexual dimorphism and projections to gonadotropin-releasing hormone neurons. Endocrinology 147:5817-5825

44. Mayer C, Acosta-Martinez M, Dubois SL, Wolfe A, Radovick S, Boehm U, Levine JE 2010 Timing and completion of puberty in female mice depend on estrogen receptor alpha-signaling in kisspeptin neurons. Proc Natl Acad Sci U S A 107:22693-22698

45. Redmond JS, Baez-Sandoval GM, Spell KM, Spencer TE, Lents CA, Williams GL, Amstalden M 2011 Developmental Changes in Hypothalamic Kiss1 Expression during Activation of the Pulsatile Release of Luteinising Hormone in Maturing Ewe Lambs. J Neuroendocrinol 23:815-822

46. Smith JT, Coolen LM, Kriegsfeld LJ, Sari IP, Jaafarzadehshirazi MR, Maltby M, Bateman K, Goodman RL, Tilbrook AJ, Ubuka T, Bentley GE, Clarke IJ, Lehman MN 2008 Variation in kisspeptin and RFamide-related peptide (RFRP) expression and terminal connections to gonadotropin-releasing hormone neurons in the brain: a novel medium for seasonal breeding in the sheep. Endocrinology 149:5770-5782

47. Backholer K, Smith J, Clarke IJ 2009 Melanocortins may stimulate reproduction by activating orexin neurons in the dorsomedial hypothalamus and kisspeptin neurons in the preoptic area of the ewe. Endocrinology 150:5488-5497

48. Merkley CM, Coolen LM, Goodman RL, Lehman MN 2011 Direct projections of arcuate kndy (kisspeptin/neurokinin b/dynorphin) neurons to gnrh neurons in the sheep. Society for Neuroscience, Washington, D.C., 2011

49. Smith JT, Li Q, Pereira A, Clarke IJ 2009 Kisspeptin neurons in the ovine arcuate nucleus and preoptic area are involved in the preovulatory luteinizing hormone surge. Endocrinology $150: 5530-5538$ 
50. Kinsey-Jones JS, Grachev P, Li XF, Lin YS, Milligan SR, Lightman SL, O’Byrne KT 2012 The inhibitory effects of neurokinin B on GnRH pulse generator frequency in the female rat. Endocrinology 153:307-315

51. Navarro VM, Gottsch ML, Wu M, Garcia-Galiano D, Hobbs SJ, Bosch MA, Pinilla L, Clifton DK, Dearth A, Ronnekleiv OK, Braun RE, Palmiter RD, Tena-Sempere M, Alreja M, Steiner RA 2011 Regulation of NKB pathways and their roles in control of Kiss 1 neurons in the arcuate nucleus of the male mouse. Endocrinology 152:4265-4275

52. Kauffman AS, Navarro VM, Kim J, Clifton D, Steiner RA 2009 Sex Differences in the Regulation of Kiss 1/NKB Neurons in Juvenile Mice: Implications for the Timing of Puberty. Am J Physiol Endocrinol Metab 297:E1212-E1221

53. Lehman MN, Coolen LM, Goodman RL 2010 Minireview: kisspeptin/neurokinin B/dynorphin (KNDy) cells of the arcuate nucleus: a central node in the control of gonadotropin-releasing hormone secretion. Endocrinology 151:3479-3489

54. Garcia-Galiano D, van Ingen Schenau D, Leon S, Krajnc-Franken MA, Manfredi-Lozano M, Romero-Ruiz A, Navarro VM, Gaytan F, van Noort PI, Pinilla L, Blomenrohr M, TenaSempere M 2012 Kisspeptin Signaling Is Indispensable for Neurokinin B, but not Glutamate, Stimulation of Gonadotropin Secretion in Mice. Endocrinology 153:316-328

55. Cheng G, Coolen LM, Padmanabhan V, Goodman RL, Lehman MN 2010 The kisspeptin/neurokinin B/dynorphin (KNDy) cell population of the arcuate nucleus: sex differences and effects of prenatal testosterone in sheep. Endocrinology 151:301-311

56. Kas MJ, Bruijnzeel AW, Haanstra JR, Wiegant VM, Adan RA 2005 Differential regulation of agouti-related protein and neuropeptide Y in hypothalamic neurons following a stressful event. J Mol Endocrinol 35:159-16449.

57. Dellovade TL, Merchenthaler I 2004 Estrogen regulation of neurokinin B gene expression in the mouse arcuate nucleus is mediated by estrogen receptor alpha. Endocrinology 145:736-742 


\section{FIGURE LEGENDS}

Figure 1. A, LH profiles from individual prepubertal ewes that were treated with water (open circles) or $100 \mu \mathrm{g}$ of senktide (closed circles). B, Mean LH 24 min before (Pre) and 24 min after (Post) iv injection. C, LH profiles from individual prepubertal ewes that were treated with water (open circles) or $500 \mu \mathrm{g}$ of senktide (closed circles). D, Mean LH 24 min before (Pre) and 24 min after (Post) iv injection. Arrows indicate time of iv injection. *, LH pulses. Significance $(P<0.05)$ is indicated by [stroke]T.

Figure 2. Group means $( \pm \mathrm{SEM})$ for mean LH (A), LH pulse frequency (B) and LH pulse amplitude (C) in prepubertal and postpubertal females (left) and age-matched males (right). Open bars represent gonadintact animals; postpubertal ewes are in the early follicular (EF) phase. Closed bars represent GNDX animals. Significance $(P<0.05)$ within sex is indicated by differing superscripts.

Figure 3. A-D, Photomicrographs of kisspeptin-positive neurons in the caudal portion of the ARC. Sections are from representative prepubertal and postpubertal females that were intact (A and B) or OVX $\left(\mathrm{C}\right.$ and D). E, Mean $\left({ }_{+} \mathrm{SEM}\right)$ number of kisspeptin-positive neurons in the ARC of prepubertal and postpubertal females (left) or age-matched males (right). Significance $(P<0.05)$ within sex is indicated by differing superscripts. *, Significant $(P<0.05)$ difference between intact female groups. Scale bar, $200 \mu \mathrm{m}$.

Figure 4. Top panels, 3D reconstruction of confocal microscopic images of GnRH neurons (green) lacking (A) and with (B) kisspeptin (red) close contacts from a prepubertal and postpubertal ewe, respectively. B, Kisspeptin-positive close contacts (arrowheads) with incoming kisspeptin fiber (arrows) adjacent to the GnRH neuron. Bottom panels, Mean ( one kisspeptin close contact $(\mathrm{C})$ and the mean $\left({ }_{+} \mathrm{SEM}\right)$ number of close contacts per GnRH neuron that received at least one close apposition (D). Open bars represent intact ewes, and closed bars represent OVX ewes. Significance $(P<0.05)$ is indicated by differing superscripts. Images were visualized using a 63x/1.4 oil immersion objective. 
Figure 5. A-D, Representative photomicrographs of NKB-positive neurons in the caudal portion of the ARC from ovary-intact (A and B) and $\mathrm{OVX}(\mathrm{C}$ and $\mathrm{D})$ prepubertal or postpubertal females. E, Mean $(+\mathrm{SEM})$ number of NKB-positive neurons in the ARC from prepubertal and postpubertal females (left) and age-matched males (right). Open bars represent gonad-intact animals, and closed bars represent GNDX animals. Significance $(P<0.05)$ within sex is indicated by difference in superscripts. *, Significant $(P<0.05)$ age by GNDX interaction. Scale bar, $200 \mu \mathrm{m}$. 


\section{FIGURES}

Figure 1
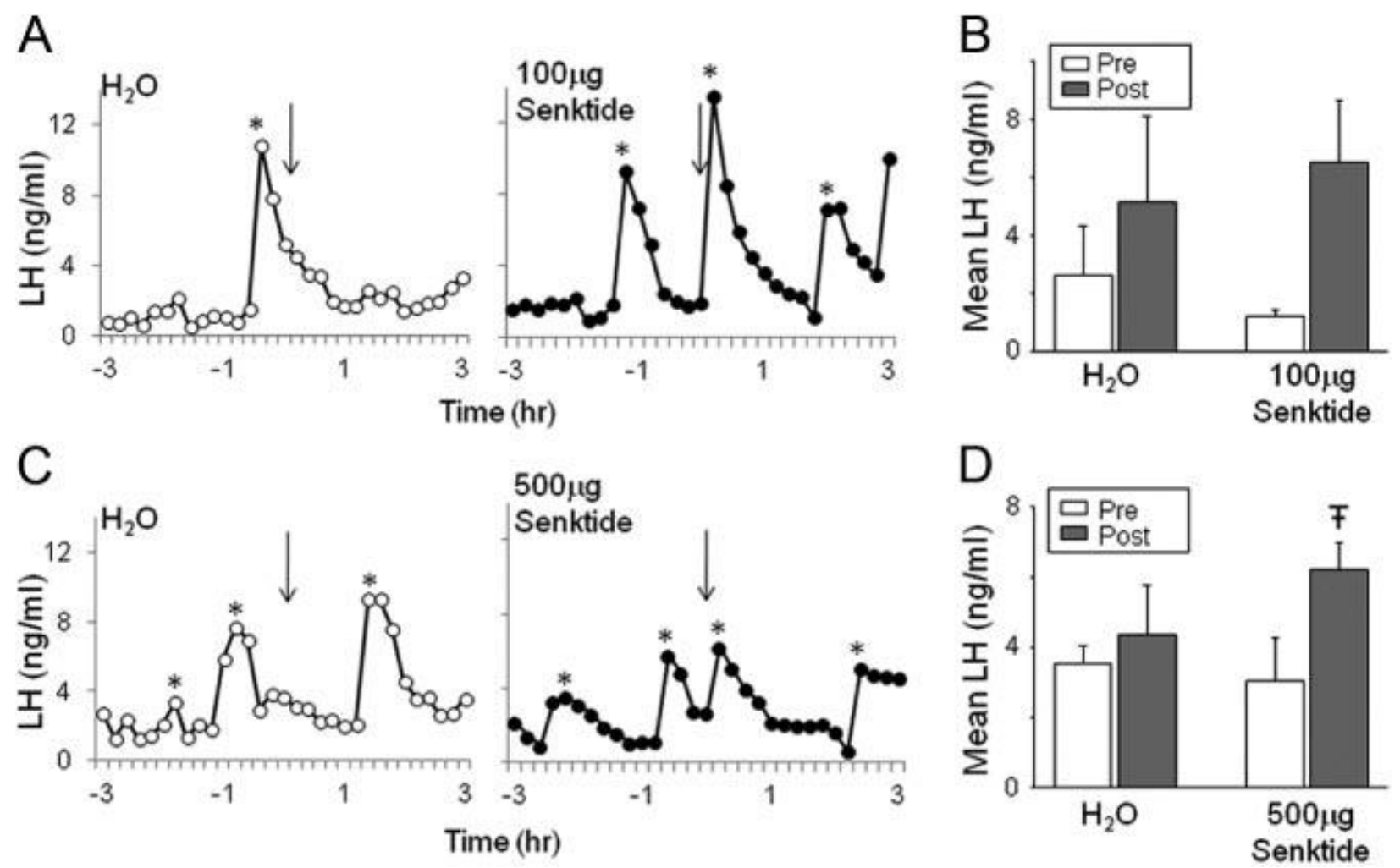
Figure 2
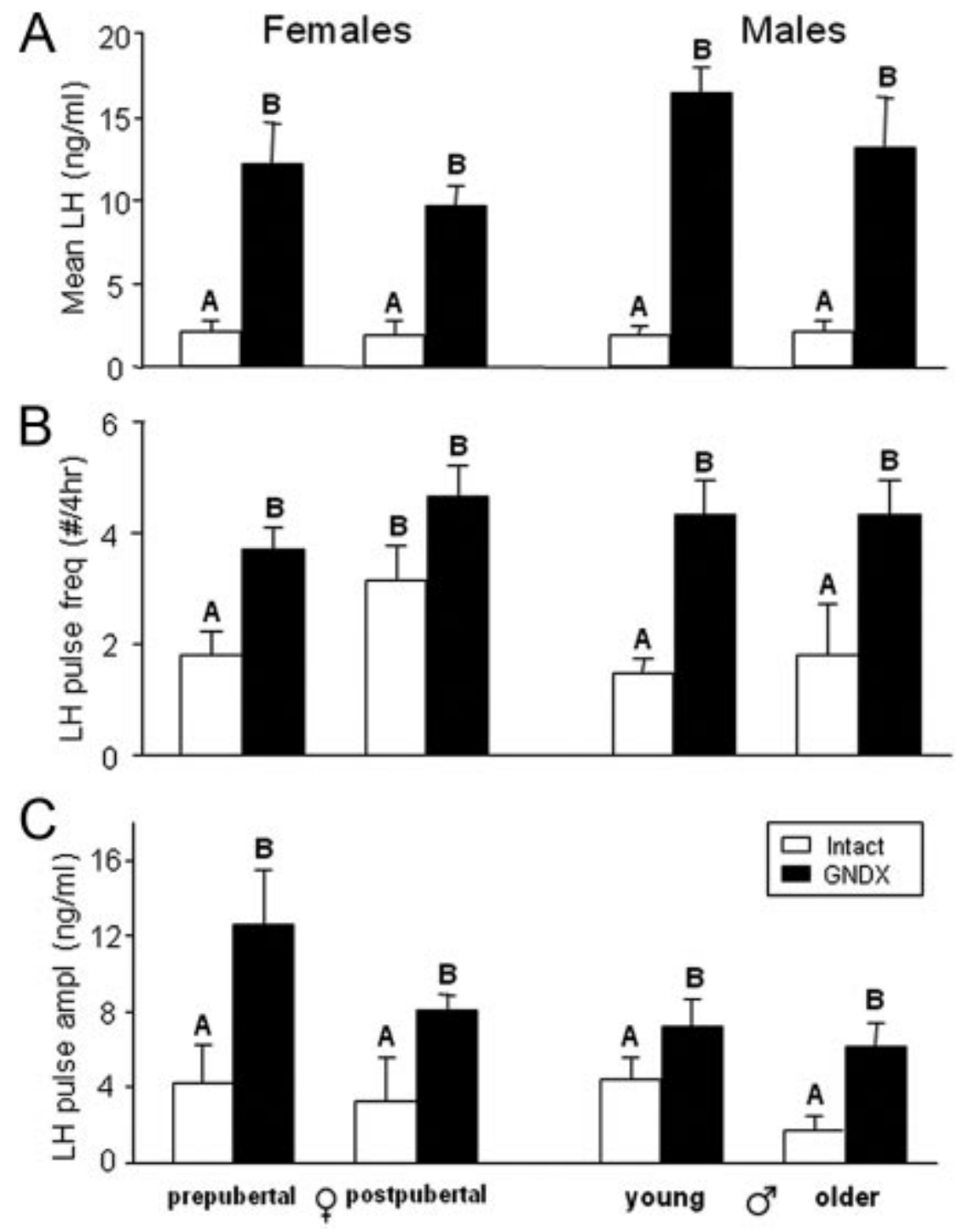
Figure 3

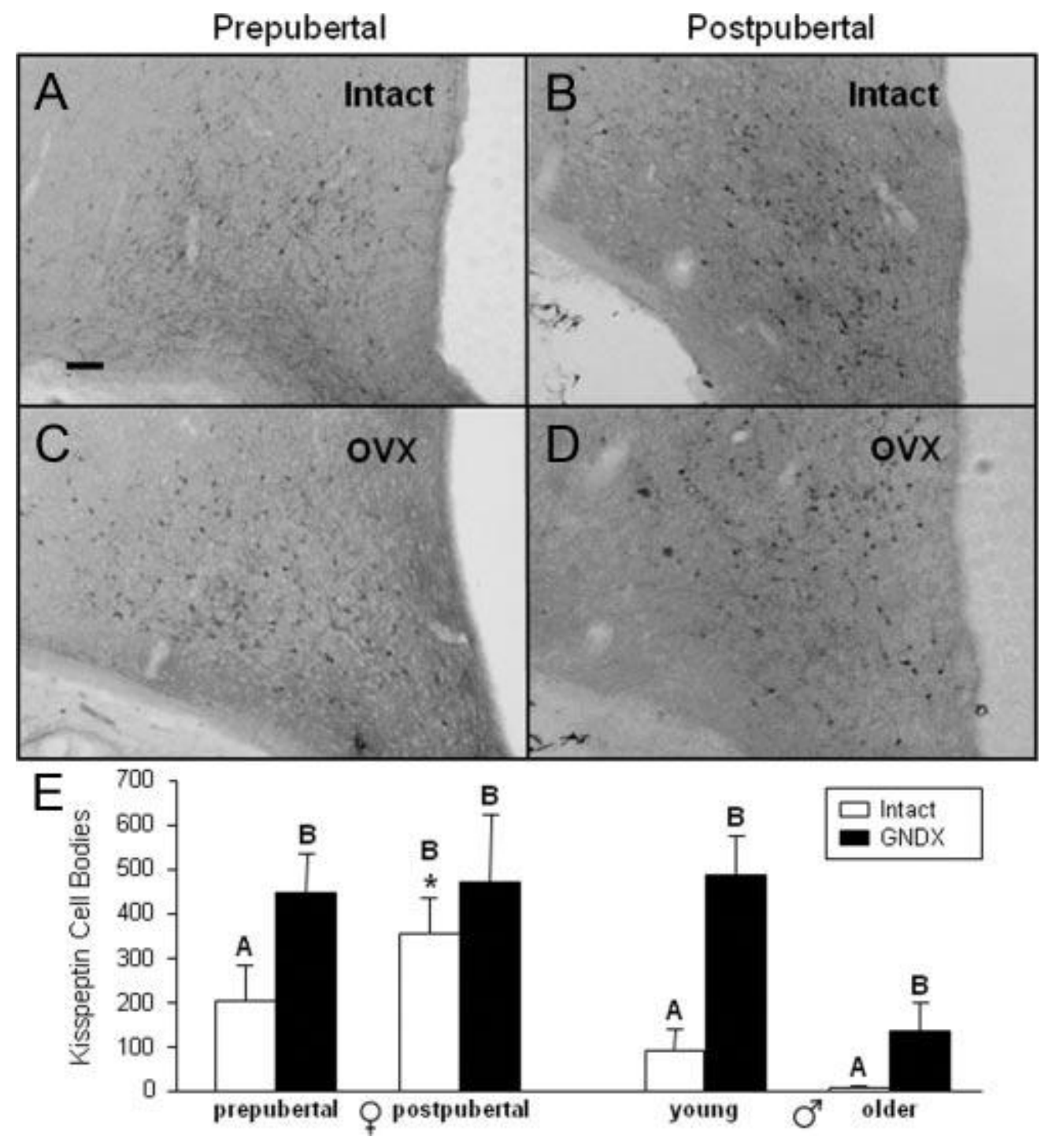


Figure 4

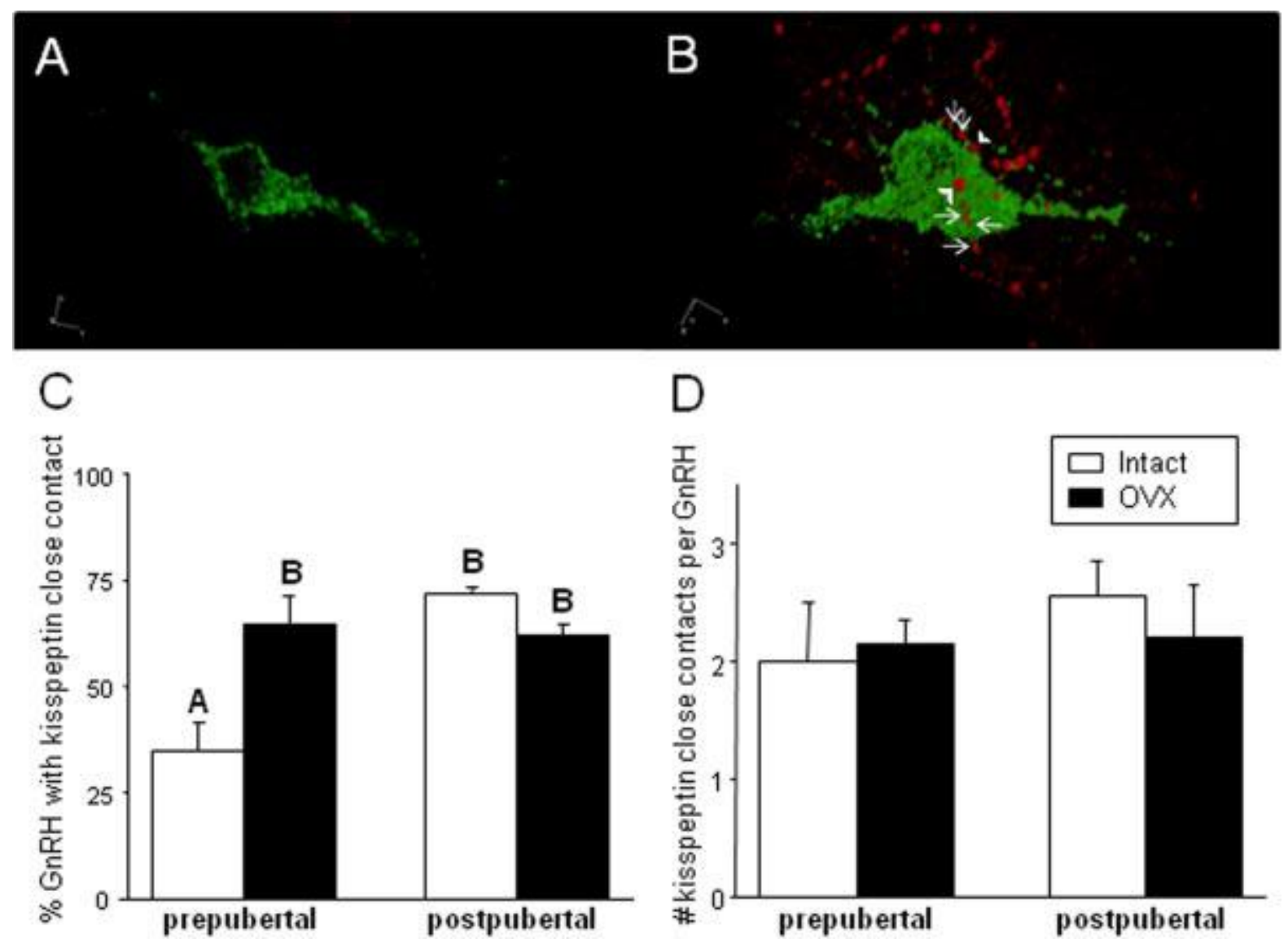


Figure 5

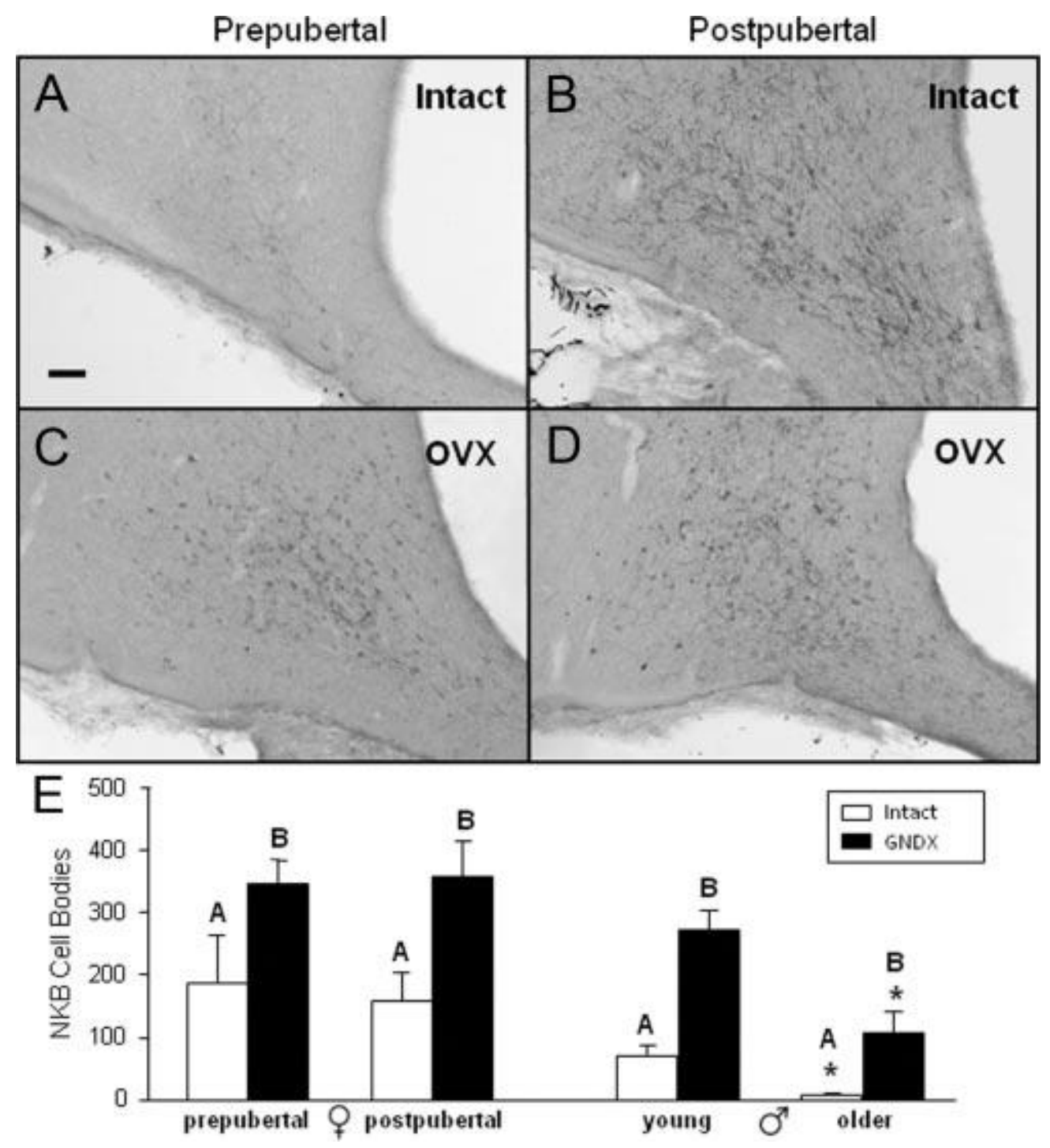




\section{CHAPTER 3}

\section{ORPHANIN FQ ACTS AT THE HYPOTHALAMUS TO SUPPRESS GONADOTROPIN RELEASING HORMONE SECRETION IN THE EWE}

Nestor $\mathrm{CC}^{1}$, Singh $\mathrm{SR}^{1}$, Holaskova $\mathrm{I}^{1}$, Valent $\mathrm{M}^{1}$, Flores JA ${ }^{2}$, Billings $\mathrm{HJ}^{3}$, Connors $\mathrm{JM}^{1}$, Hileman $\mathrm{SM}^{1}$, Goodman $\mathrm{RL}^{1}$

${ }^{1}$ Department of Physiology and Pharmacology School of Medicine

${ }^{2}$ Department of Biology Eberly College of Arts and Sciences

${ }^{3}$ Department of Neurobiology and Anatomy

West Virginia University, Morgantown WV 26506

Running Heading: OFQ inhibits GnRH in sheep 


\section{ABSTRACT}

Recently, orphanin FQ (OFQ), an opioid-like peptide that acts via its receptor, ORL-1, has been shown to be expressed throughout the ovine POA and hypothalamus including the external zone of the median eminence. Previously it has been shown that infusion of an OFQ agonist into the third ventricle suppressed luteinizing hormone (LH) secretion in ovariectomized (OVX) ewes. In this study, we determined if OFQ acts at the pituitary and/or the hypothalamus to inhibit LH secretion. To test the hypothesis that OFQ acts at the pituitary, an in vitro cell culture approach was used. Pituitaries were removed from eight sheep, dispersed and incubated with or without OFQ (550 pmole or 5500 pmole) and treated with increasing doses of $\mathrm{GnRH}\left(4 \times 10^{-12} \mathrm{M}-4 \times 10^{-9} \mathrm{M}\right)$. Following a three hour incubation, media was harvested and LH was measured using radioimmunoassay. The two highest doses of GnRH added elicited a significant increase in LH when compared to anterior pituitary cells incubated with no GnRH. Neither dose of OFQ inhibited GnRH-induced LH secretion. To test the hypothesis that OFQ acts at the hypothalamus, we administered an OFQ agonist ([ $\operatorname{Arg}^{14}$, Lys $\left.\left.{ }^{15}\right] \mathrm{OFQ}\right)$ into the third ventricle of OVX ewes and measured GnRH secretion in the hypophyseal portal circulation. A single chronic guide tube was placed into the third ventricle of OVX ewes. Portal and jugular blood were simultaneously collected every ten minutes for four hours before and for four hours during infusion of either the OFQ agonist ( $\mathrm{n}=5$; $5 \mathrm{nmole} / \mathrm{hr}$ ) or saline $(\mathrm{n}=5 ; 60 \mu \mathrm{l} / \mathrm{hr}$ ) into the third ventricle. Infusion of OFQ agonist into the third ventricle inhibited GnRH pulse frequency during the last two hours of infusion, while infusion of saline has no effect on GnRH or LH secretion. In summary, OFQ appears to act primarily at the hypothalamus to inhibit GnRH, and subsequently LH, secretion. 


\section{INTRODUCTION}

For most species, subpopulations of GnRH cell bodies exist in the diagonal band of the broca, preoptic area, the anterior hypothalamic area and the medial basal hypothalamus with axonal projections that terminate in the external zone of the median eminence (1-4). GnRH is transported via hypophyseal portal vessels to the anterior pituitary and controls the release of the pituitary gonadotropins, luteinizing hormone (LH) and follicle stimulating hormone (FSH). In the ewe, GnRH and LH secretion occur in episodic patterns; a pulse of GnRH secretion stimulates a subsequent pulse of LH secretion. Late in the follicular phase of the estrous cycle, rising levels of plasma estradiol $\left(\mathrm{E}_{2}\right)$ act as a stimulus for the preovulatory $\mathrm{GnRH} / \mathrm{LH}$ surge. In contrast, during the rest of the estrous cycle relatively low levels of $\mathrm{E}_{2}$ serves to inhibit GnRH/LH pulse amplitude while progesterone acts to primarily inhibit GnRH/LH pulse frequency (5). However, GnRH neurons are devoid of the receptors, estrogen receptor- $\alpha(\operatorname{ER} \alpha ;(6,7))$ and progesterone receptor (PR; (8)), that mediate steroid positive and negative feedback. Therefore, other interneurons must mediate the effects of these steroids on GnRH release. Consequently, neurons that release OFQ are possible candidates to mediate steroid negative feedback.

Orphanin FQ (OFQ), also named nociceptin, was discovered by two independent groups $(9,10)$. OFQ was named for its binding to an orphan receptor, opioid receptor-like 1 (ORL-1), and the first and last amino acids in the peptide sequence, phenylalanine (F) and glutamine (Q) as well as called nociceptin for its pro-nociceptive properties. The peptide and its receptor are found throughout the central nervous system and, since identified, OFQ has been shown to participate in various physiological processes including pain perception, learning, and memory as well as renal and cardiovascular function (11). OFQ is found in the preoptic area, hypothalamus and median eminence in rats $(12,13)$ and sheep $(14)$. Furthermore, OFQ given icv has been shown to inhibit GnRH and LH secretion in the rat $(15,16)$ and LH secretion in the ewe (14). Although most evidence suggests that the effect of OFQ on LH in the rat is at the hypothalamus, the presence of OFQ in the external zone of the median eminence of sheep raises the possibility of a direct action of OFQ at the pituitary. The sheep model is ideally suited to differentiate 
hypothalamic vs anterior pituitary action of this opioid because both GnRH in hypophyseal portal blood and LH in peripheral blood can be assessed simultaneously in an unanesthetized animal (17).

Herein we hypothesize that OFQ acts directly at the anterior pituitary to inhibit LH secretion and at the hypothalamus to inhibit GnRH release. To examine a potential direct effect of OFQ at the anterior pituitary, we measured LH release from cultured adult ewe anterior pituitary cells with increasing concentrations of OFQ alone and with increasing concentrations of GnRH in the absence or presence of OFQ. To examine a potential effect of OFQ at the hypothalamus, we infused an OFQ receptor agonist into the third ventricle of ewes and collected hypophyseal portal and jugular blood simultaneously for the measurement of GnRH and LH, respectively.

\section{MATERIALS AND METHODS}

\section{Animals}

Adult ewes of predominantly the Suffolk breed (>3yrs) were used in this study. For Experiment 1, anterior pituitaries $(n=8)$ were collected from breeding season ewes housed outdoors on natural photoperiod who had received a daily diet of hay and water ad libitum. For Experiment 2, non-breeding season ewes $(n=10)$ were housed indoors for 14-17 days on a photoperiod that simulated natural daylength and received a daily ration of alfalfa pellets with free access to water. All procedures were approved by the West Virginia University Animal Care and Use Committee and followed NIH guidelines for use of animals in research.

\section{Pituitary dispersal}

For experiment 1 , ewes $(n=8)$ were euthanized with an overdose of sodium pentobarbital and pituitaries were removed and dispersed as previously described (18). Briefly, each anterior pituitary was cut into $1 \mathrm{~mm}$ cubes using a sterile scalpel and forceps in Hanks balanced salt solution (Sigma), then centrifudged at $900 \mathrm{rpm}$ for $2 \mathrm{~min}$. Tissue was then incubated in a flask containing $10 \mathrm{ml} \mathrm{Hanks} \mathrm{solution,} 10 \mathrm{mg}$ collagenase type XI (Sigma), $125 \mu$ g DNase 1 (Sigma) and 100 mg bovine serum albumin (BSA; Sigma) which was placed in a $37^{\circ} \mathrm{C}$ shaking water bath at $150 \mathrm{rpm}$ for $30 \mathrm{~min}$. Contents of the flask were next moved in and out of a plastic large bore pipette approximately 20 times and then the flask was returned to 
the $37^{\circ} \mathrm{C}$ shaking water bath for $30 \mathrm{~min}$. The contents were then centrifuged for $5 \mathrm{~min}$ at $900 \mathrm{rpm}$ and the supernatant was discarded. Cells were placed in $10 \mathrm{ml}$ Hanks solution, $25 \mathrm{mg}$ pancreatin, $125 \mu \mathrm{g}$ DNase1 and $100 \mathrm{mg}$ BSA and incubated for $1 \mathrm{hr}$ in a $37^{\circ} \mathrm{C}$ shaking water bath. This suspension was then moved in and out of a sterile Pasteur pipette approximately 20 times and returned to the water bath for another $30 \mathrm{~min}$. After centrifugation for $5 \mathrm{~min}$, the supernatant was discarded and cells added to $1 \mathrm{ml}$ DMEM (Dulbecco's Modified Eagle Medium) with $10 \%$ FBS (fetal bovine seurm), 1mg DNase1 and $1 \mathrm{mg}$ trypsin inhibitor. $10 \mathrm{ml}$ of the DMEM-FBS solution was added to cells, they were lightly vortexed and centrifuged for $5 \mathrm{~min}$, after which the supernatant was discarded. After two more repetitions of the prior step, cells were diluted to $1 \mathrm{ml}$ with DMEM-FBS, counted using a hemocytometer and placed in 24 well plates (100,000 cells in $1 \mathrm{ml}$ DMEM-FBS/well; Fisher). Plates were incubated in a humidified chamber at $37^{\circ} \mathrm{C}$ with $5 \% \mathrm{CO}_{2}$ for 3 days prior to treatment. Cell viability was assessed using the trypan blue exclusion method (19) and was greater than $95 \%$.

\section{Surgeries}

For Experiment 2, ewes were first ovariectomized (OVX) by midventral laparotomy under gas anesthesia (oxygen $+3 \%$ isoflurane), followed immediately by permanent insertion of a 16 gauge guide tube into the third ventricle as previously described (20). Briefly, a $2 \mathrm{~cm}$ hole was drilled in the skull at bregma, the sagittal sinus ligated, and $1.5 \mathrm{ml}$ of a radioopaque dye (Omnipaque 350; Webster Veterinary Supply; Devens, MA) injected into one lateral ventricle. Lateral and frontal x-rays were taken to visualize placement of the guide tube to the middle area of the third ventricle and 3 to $4 \mathrm{~mm}$ posterior to its rostral edge. The needle hub was plugged to prevent loss of cerebrospinal fluid and, together with a plastic protective cap, was cemented in place using dental acrylic. All ewes were treated pre- and postoperatively with Penicillin Procaine G (Webster Veterinary Supply), Dexamethosone (Webster Veterinary Supply), and FluMeglumine (Webster Veterinary Supply) as previously described (20) and allowed at least 1 week for recovery. Following recovery, a hypophyseal portal cannula was surgically inserted under anesthesia as previously described (17). Briefly, a skin incision was made to expose the nasal bone with caution taken to avoid facial veins. A pentagonal piece of nasal bone was removed using 
an osteotome and mallet, allowing access to the nasal turbinates and septum, which were removed using bone rongeurs to expose the face of the sphenoid bone. Using a bone drill, a tunnel was created that was large enough to accommodate the portal cannula and extended to the dura mater adjacent to the face of the anterior pituitary (approximately $10-10.4 \mathrm{~cm}$ ). The dura mater was removed and the portal cannula placed 1-2 mm from the surface of the anterior pituitary. The apparatus was cemented into place using dental acrylic, filled with saline, and plugged. Ewes were allowed to recover for 7 to 10 days before portal blood collection.

\section{Experimental Design}

\section{Experiment 1a: Does OFQ alone inhibit LH secretion?}

Each pituitary $(n=4)$ was dispersed and 100,000 cells were placed in each well of a 24-well plate/ewe. Each plate was divided into six groups for OFQ treatment ( $\mathrm{n}=4$ wells/treatment): no OFQ, 0.55 pmoles, 5.5 pmoles, 55 pmoles, 550 pmoles and 5500 pmoles of OFQ (Tocris). OFQ was applied for 3 hrs and media was harvested, after which cells were challenged with $50 \mathrm{mM} \mathrm{KCl}$, which stimulates maximal LH release from anterior pituitary cells (21), for $3 \mathrm{hrs}$ and media was again harvested. All media was stored at $-20^{\circ} \mathrm{C}$ until time of assay.

\section{Experiment 1b: Does OFQ inhibit GnRH-induced LH secretion in vitro?}

Each pituitary (n=8) was dispersed and 100,000 cells were placed in each well of a 24-well plate. Enough cells were recovered from each ewe for three 24 -well plates/ewe. These plates were divided into three groups for OFQ treatment: one plate received no OFQ, the second plate received 550 pmoles, and the third plate received 5500 pmoles of OFQ. These doses of OFQ were chosen based on administration in previous in vitro (22) and in vivo $(14-16,23)$ studies. Each plate was divided into six groups for GnRH treatment (n=4 wells per dose): no GnRH, 4 pM, 40 pM, 220 pM, 400 pM and 4000 pM of GnRH. These doses of GnRH were chosen based on a previous study using ovine anterior pituitary cells (24). OFQ treatment was applied $30 \mathrm{~min}$ prior to and during a $3 \mathrm{hr}$ incubation with each dose of $\mathrm{GnRH}$ followed by harvesting of the media. At the end of incubation, all cells were challenged with $50 \mathrm{mM} \mathrm{KCl}$ 
in DMEM for $3 \mathrm{hrs}$ and again media was harvested. All harvested media was stored at $-20^{\circ} \mathrm{C}$ until time of assay.

\section{Experiment 2: Does an OFQ agonist, [Arg14,Lys15] OFQ, inhibit GnRH secretion in vivo?}

Hypophyseal portal and jugular blood samples were collected from ten ewes at 7-10 days after portal cannula insertion. Twenty-four hours prior to the collection, each ewe had a 16 gauge indwelling catheter inserted into each jugular vein using local anesthetic. On the day of the collection, each ewe was heparinized and portal veins lesioned as previously described (17). Portal and jugular blood samples were collected using peristaltic pumps every $10 \mathrm{~min}$ for $4 \mathrm{hrs}$ before and $4 \mathrm{hrs}$ during infusion of either saline $(\mathrm{n}=5 ; 60 \mu \mathrm{l} / \mathrm{hr})$ or OFQ agonist ( $\mathrm{n}=5 ; 5 \mathrm{nmoles} / \mathrm{hr}$; Tocris). Portal samples were collected into tubes containing $0.5 \mathrm{ml}$ bacitracin (Sigma; $423 \mathrm{mg} / 100 \mathrm{ml}$ saline) submersed in an ice bath to prevent the loss of GnRH. Portal plasma ( $750 \mu \mathrm{l})$ for GnRH measurements was extracted within 1-2 hrs of collection using $2 \mathrm{ml}$ methanol, then dried and stored at $-20^{\circ} \mathrm{C}$. Jugular plasma for $\mathrm{LH}$ measurements was stored at $-20{ }^{\circ} \mathrm{C}$.

\section{Data analysis}

Assays: LH concentrations were measured in duplicate with a radioimmunoassay using 100-200 $\mu$ lof media and plasma with reagents provided by the National Hormone and Peptide Program (Torrance, CA) as previously described (25). LH assay sensitivity averaged $0.12 \mathrm{ng} /$ tube (NIH S24) and intra- and interassay coefficients of variation were $17.1 \%$ and $22.5 \%$, respectively. GnRH concentrations were measured in extracts of portal plasma after reconstitution with $250 \mu \mathrm{l}$ of phosphate buffered saline with $0.1 \%$ Gelatin (Sigma) or phosphate buffer with $0.1 \%$ triton-x (Sigma) by radioimmunoassay $(26,27)$ using two different antibodies (BDS 037; R 1245). Samples were assayed in duplicates of $100 \mu \mathrm{l}$ (equivalent to $300 \mu 1$ of plasma) with all samples for each ewe being analyzed in the same assay. Intraand interassay variability were $15.9 \%$ and $23.4 \%$, respectively. GnRH assay sensitivity was $0.14 \mathrm{pg} /$ tube.

Statistics: In experiment 1a, pituitaries were collected from follicular phase $(n=1)$, luteal phase $(n=1)$ and OVX ewes $(n=2)$. In experiment $1 b$, pituitaries were collected from follicular phase $(n=3)$, luteal phase $(n=2)$ and OVX ewes $(n=3)$. Since there was no difference in LH response among these groups, data 
from all three groups were combined for analysis and presentation. For experiment 1a, mean LH was calculated by averaging wells in each treatment group (4 wells/group) to determine mean concentration for each ewe after each dose of OFQ. These data were then transformed to the reciprocal to establish normality and analyzed using one-way ANOVA. For experiment $1 \mathrm{~b}$, mean LH was calculated by averaging wells in each treatment group (4 wells/group), transformed to the reciprocal to establish normality and analyzed using two-way ANOVA with a Holm-Sidak post-hoc test.

For experiment 2, GnRH values are reported in $\mathrm{pg} / \mathrm{min}$ to compensate for changes in blood flow during time of collection. GnRH pulses were identified using Cluster 8 (M. Johnson; Keswick, VA) and LH pulses were identified using previously described criteria (Goodman and Karsch, 1980). For analysis of mean GnRH and LH, pulse frequencies and amplitudes, all variables were divided into 2 hour time bins (i.e., 0-2, 2-4, 4-6 and 6-8 hours). Within each treatment group, GnRH and LH pulse frequency were analyzed using Friedman Repeated Measures Analysis of Variance on Ranks with a Tukey post-hoc test. Mean LH concentrations, mean GnRH concentrations, mean LH pulse amplitude, mean GnRH pulse amplitude and mean GnRH baseline were analyzed using a repeated measure one-way ANOVA with a Holm-Sidak post-hoc test. Mean GnRH baseline (identified by Cluster 8 software) was calculated by averaging concentrations for each time bin with the exclusion of values during a pulse episode. GnRH pulse amplitude was calculated by summation of the GnRH concentrations during a pulsatile event as determined by Cluster 8. Differences were considered to be significant at $\mathrm{p}<0.05$.

\section{RESULTS:}

\section{Experiment 1: Can OFQ inhibit LH release from anterior pituitary cells in vitro?}

In experiment 1a, OFQ alone had no significant effect on LH secretion (Fig 1A) and cells responded to a $50 \mathrm{mM} \mathrm{KCl}$ with an increase in mean LH concentration slightly higher than that seen during the OFQ challenge (Fig 1B), which confirmed cell viability. In experiment $1 \mathrm{~b}$, mean $\mathrm{LH}$ release from anterior pituitary cells was significantly greater than control values following application of the two highest GnRH concentrations, 400 and $4000 \mathrm{pM}$ (Fig 2A). The greatest increase in LH release, greater than 2 fold compared to control, occurred at the highest dose of GnRH. Incubation with 550 pmole or 5500 pmole of 
OFQ had no significant effect on the GnRH-induced LH release (Fig 2A). Following a $50 \mathrm{mM} \mathrm{KCl}$ challenge, cells in culture responded with an increase in mean LH concentration comparable to that previously observed following administration of the highest dose of GnRH (Fig 2B).

\section{Experiment 2: Can an OFQ receptor agonist, [Arg14,Lys15] OFQ, inhibit GnRH secretion in vivo?}

As can be seen in the representative GnRH and LH profiles in Figure 3, infusion of an OFQ receptor agonist in the third ventricle, in contrast to saline, produced a dramatic reduction of LH secretion as well as decrease in GnRH pulse frequency and an increase in GnRH baseline in OVX ewes (Fig 3). Saline infusion had no significant effect on mean LH concentration (Fig 4A) or mean GnRH concentration (Fig 4B). Infusion of the OFQ agonist significantly reduced mean LH within the final two hours of treatment (Fig 4 C), while having no significant effect on mean GnRH concentration (Fig 4D). Mean LH pulse amplitude (Fig 5A) and mean GnRH pulse amplitude (Fig 5B) was unaffected by saline infusion. Infusion of the OFQ agonist significantly reduced LH pulse amplitude in the final two hours of infusion (Fig 5C), while having no significant effect on mean GnRH pulse amplitude (Fig 5D). Mean LH and GnRH pulse frequency (Fig 6A and 6B, respectively) were unaltered by saline infusion, while in OFQ agonist-infused OVX ewes, mean LH and GnRH pulse frequency (Fig 6C and 6D, respectively) were significantly reduced during the final two hours of infusion. Interestingly, we did observe an increase in baseline GnRH concentration for 4 out of 5 OFQ agonist-infused ewes. Mean GnRH baseline concentration significantly increased during the final two hours of OFQ agonist infusion, but not during saline infusion (Fig 7). Finally, given that each GnRH pulse should result in a subsequent LH pulse, we analyzed whether this association was altered in OFQ agonist-infused ewes and as expected almost all GnRH pulses were followed by LH pulses. Although rare, one OFQ agonist infused ewe had one GnRH pulse unaccompanied by a detectable LH pulse, while another OFQ agonist infused ewe had an LH pulse in the absence of a detectable GnRH pulse. This did not occur in saline infused ewes. In addition to the studies reported here, we also tested the effect of OFQ agonist infusion into the lateral ventricle on LH secretion in OVX ewes. Given the distance from the third ventricle and the relative increase in cerebrospinal fluid volume experienced with this approach, we infused a dose that was four-times the 
dose $(20 \mathrm{nmole} / \mathrm{hr})$ used for the third ventricle infusions reported here and collected jugular blood samples every 12 minutes. After one hour, the infusion of OFQ agonist was discontinued because both ewes became ataxic and after another 30 min could not stand and appeared to be sedated for a total of four to five hours. Moreover, a similar alteration in locomotor activity was observed in rodents $(9,28,29)$. LH secretion in both ewes was clearly reduced (data not shown) and since no behavioral effect is seen with infusion of the OFQ agonist in the third ventricle, we suggest that this inhibition of GnRH is independent of sedation.

\section{DISCUSSION}

Herein we investigated the site of action of OFQ in controlling LH secretion in the ewe. OFQ alone had no effect on LH release from anterior pituitary cells in vitro. Furthermore, OFQ did not block GnRH-induced LH release from isolated anterior pituitary cells. Our in vivo work demonstrated that OFQ acts at the level of the hypothalamus to inhibit GnRH pulse frequency and LH release as well as increase GnRH baseline concentration. Thus, we suggest that the inhibitory action of OFQ on LH secretion appears to reside primarily at the level of the hypothalamus.

Evidence of a central role for OFQ in control of LH has accumulated over the past fifteen years. However, one cannot rule out the possibility that OFQ inhibits LH secretion directly at the anterior pituitary given that the pituitary is bathed in the same cerebrospinal fluid in which the drug is administered. Furthermore, in rodents $(12,13)$ and sheep (14) OFQ exists in the median eminence and thus may be released into the hypophyseal portal vessels. However, to date, an adequate assay for measurement of OFQ in hypophyseal portal blood does not exist. And, while presence of the OFQ receptor, ORL-1, in the rat pituitary remains controversial $(15,30,31)$, the question of whether or not OFQ acts to inhibit LH directly at the anterior pituitary remains open. Herein we report that, as expected, GnRH induced an increase in LH release from cultured anterior pituitary cells, but that OFQ alone had no effect on LH release nor did this opioid have an effect on GnRH-induced LH release. Although our two largest doses of OFQ were similar to doses used during icv administration that have been shown to inhibit 
LH secretion in the rat $(15,16)$ and the ewe $(14)$, and thus should have been adequate, we cannot eliminate the possibility that higher doses of OFQ might have been effective.

In vivo experiments in rats demonstrate that icv administration of OFQ inhibits GnRH concentrations in push-pull perfusates at the median eminence $(15,16)$. However, the push-pull technique is an indirect measure of the amount of $\mathrm{GnRH}$ that reaches the anterior pituitary. Herein we simultaneously collected hypophyseal portal blood and jugular blood in sheep, making this animal an excellent in vivo model to study the effects of OFQ agonist administration on GnRH secretion.

Consistent with these earlier reports, we showed a similar inhibitory effect of an OFQ agonist on LH secretion. We did not observe a decrease in mean GnRH concentration or GnRH pulse amplitude following OFQ agonist infusion, which is not surprising given the low concentrations of GnRH even during a pulsatile event. We did observe a decrease in GnRH pulse frequency during the OFQ agonist infusion, which leads us to conclude that OFQ acts at the hypothalamus to inhibit LH secretion.

Although rare, an LH pulse did appear in the absence of a GnRH pulse during the last two hours of OFQ agonist infusion in one ewe. One plausible explanation for this would be the difficulty in detecting low amplitude GnRH pulses since the amplitude of GnRH pulses in our study were somewhat lower than would be expected based on a previous report (32). Also, during the latter part of the OFQ infusion period, we observed an increase in GnRH baseline in four of five OFQ-infused animals. This increase in baseline might be due to low amplitude, but high pulse freqendcy of GnRH secretion, but given our 10 min sampling we could not discern such an alteration in GnRH pulse patterns. We are currently investigating this possibility with a shorter collection interval between samples ( 2 minutes) which will allow us to analyze GnRH pulse dynamics. Conversely, yet equally rare, was a GnRH pulse in the absence of a subsequent LH pulse. Therefore, it is possible that OFQ could cause the release of an inhibitory neuropeptide, which could act directly at the anterior pituitary to inhibit LH secretion. One such inhibitory neuropeptide is gonadotropin inhibiting hormone which can inhibit GnRH-induced LH secretion in the ewe (33) and might explain the decrease in mean LH and LH pulse amplitude while mean GnRH concentrations and GnRH pulse amplitude did not change. 
In vitro cellular recordings from GnRH neurons from guinea pig hypothalamic slices have shown that OFQ inhibits these cells by increasing inwardly-rectifying potassium channel conductance (34). Further work with hypothalamic slice preparations reveals that OFQ can inhibit forskolin-induced GnRH secretion (23) and basal GnRH release (15). The simplest explanation for OFQ inhibition of GnRH/LH secretion would be direct inhibition on GnRH perikarya. A recent report in the rat showed OFQ cell bodies exist throughout the hypothalamus (13), which is consistent with data in the ewe that OFQ cell bodies are found in the POA and hypothalamus $(14,35)$. Furthermore, in the ewe, OFQ neurons in the hypothalamus, but not the POA, contain steroid receptors (35), raising the possibility that these neurons could mediate steroid negative feedback in sheep, a possibility that is tested in the next chapter. Although there is a general description of where ORL-1 is located (30), the individual neurons within the POA and hypothalamus that OFQ could influence directly have yet to be identified. Based on OFQ cell body distribution, work has been done to identify if OFQ neurons contain other neuropeptides. Within the POA of sheep, OFQ highly colocalizes (>90\%) with GnRH neurons (14), which is consistent with the recent evidence that OFQ neurons in the POA of sheep do not contain steroid receptors (35). Furthermore, OFQ colocalizes with approximately $14 \%$ and 50\% of proopiomelanocortin (POMC) neurons in the arcuate nucleus in the rat (13) and the ewe (35), respectively. Together with colocalization and its hyperpolarizing effects on GnRH and POMC neurons in the ARC (34), OFQ might possess an autocrine function through an ultrashort negative feedback loop on GnRH neurons. In summary, we demonstrate that the inhibitory action of OFQ on LH secretion occurs at the hypothalamus and not at the level of the anterior pituitary.

\section{ACKNOWLEDGEMENTS}

We thank Heather Bungard and Jennifer Lydon (West Virginia University Food Animal Research Facility) for care of animals. We also thank Dr. Al Parlow and the National Hormone and Peptide Program for reagents used to measure LH and Dr. Terry Nett for the GnRH-antibody used in the RIA. 


\section{REFERENCE LIST}

1. Jennes L, Stumpf WE 1986 Gonadotropin-releasing hormone immunoreactive neurons with access to fenestrated capillaries in mouse brain. Neuroscience 18:403-416

2. Silverman AJ, Jhamandas J, Renaud LP 1987 Localization of luteinizing hormone-releasing hormone (LHRH) neurons that project to the median eminence. J Neurosci 7:2312-2319

3. Goldsmith PC, Thind KK, Song T, Kim EJ, Boggant JE 1990 Location of the neuroendocrine gonadotropin-releasing hormone neurons in the monkey hypothalamus by retrograde tracing and immunostaining. J Neuroendocrinol 2:157-168

4. Jansen HT, Hileman SM, Lubbers LS, Kuehl DE, Jackson GL, Lehman MN 1997

Identification and distribution of neuroendocrine gonadotropin-releasing hormone neurons in the ewe. Biol Reprod 56:655-662

5. Goodman RL 2006 Neuroendocrine Control of the Ovarian Cycle of the Sheep. In: Neill JD ed. Physiology of Reproduction. 3rd ed. New York: Academic Press; 2389-2447

6. Herbison AE, Robinson JE, Skinner DC 1993 Distribution of estrogen receptorimmunoreactive cells in the preoptic area of the ewe: co-localization with glutamic acid decarboxylase but not luteinizing hormone-releasing hormone. Neuroendocrinology 57:751-759

7. Lehman MN, Karsch FJ 1993 Do gonadotropin-releasing hormone, tyrosine hydroxylase-, and beta-endorphin-immunoreactive neurons contain estrogen receptors? A double-label immunocytochemical study in the Suffolk ewe. Endocrinology 133:887-895

8. Skinner DC, Caraty A, Allingham R 2001 Unmasking the progesterone receptor in the preoptic area and hypothalamus of the ewe: no colocalization with gonadotropin-releasing neurons. Endocrinology 142:573-579

9. Reinscheid RK, Nothacker HP, Bourson A, Ardati A, Henningsen RA, Bunzow JR, Grandy DK, Langen H, Monsma FJ, Jr., Civelli O 1995 Orphanin FQ: a neuropeptide that activates an opioidlike G protein-coupled receptor. Science 270:792-794 
10. Meunier JC, Mollereau C, Toll L, Suaudeau C, Moisand C, Alvinerie P, Butour JL, Guillemot JC, Ferrara P, Monsarrat B, et al. 1995 Isolation and structure of the endogenous agonist of opioid receptor-like ORL1 receptor. Nature 377:532-535

11. Mogil JS, Pasternak GW 2001 The molecular and behavioral pharmacology of the orphanin FQ/nociceptin peptide and receptor family. Pharmacol Rev 53:381-415

12. Neal CR, Jr., Mansour A, Reinscheid R, Nothacker HP, Civelli O, Watson SJ, Jr. 1999 Localization of orphanin FQ (nociceptin) peptide and messenger RNA in the central nervous system of the rat. J Comp Neurol 406:503-547

13. Maolood N, Meister B 2010 Nociceptin/orphanin FQ peptide in hypothalamic neurones associated with the control of feeding behaviour. J Neuroendocrinol 22:75-82

14. Foradori CD, Amstalden M, Coolen LM, Singh SR, McManus CJ, Handa RJ, Goodman RL, Lehman MN 2007 Orphanin FQ: evidence for a role in the control of the reproductive neuroendocrine system. Endocrinology 148:4993-5001

15. An XF, Chen HP, Ma SL, Feng Y, Hao JW, Chen BY 2005 Involvement of nociceptin/orphanin FQ in release of hypothalamic GnRH mediated by ORL1 receptor in ovariectomized rats. Acta Pharmacol Sin 26:1039-1044

16. An XF, He M, Feng Y, Feng H, Yu JY 2009 Central administration of Orphanin FQ inhibits GnRH secretion by ORL1 receptor in the median eminence of freely moving ovariectomized rats. Neurosci Bull 25:1-6

17. Caraty A 1994 Sampling of Hypophyseal Portal Blood of Conscious Sheep for Direct Monitoring of Hypothalamic Neurosecretory Substances. In: Levine JE ed. Pulsatility in Neuroendocrine Systems. New York: Academic Press; 162-183

18. Silverman BL, Bettendorf M, Kaplan SL, Grumbach MM, Miller WL 1989 Regulation of growth hormone (GH) secretion by GH-releasing factor, somatostatin, and insulin-like growth factor I in ovine fetal and neonatal pituitary cells in vitro. Endocrinology 124:84-89 
19. Liu JP, Robinson PJ, Funder JW, Engler D 1990 The biosynthesis and secretion of adrenocorticotropin by the ovine anterior pituitary is predominantly regulated by arginine vasopressin (AVP). Evidence that protein kinase $\mathrm{C}$ mediates the action of AVP. J Biol Chem 265:14136-14142

20. Anderson GM, Connors JM, Hardy SL, Valent M, Goodman RL 2001 Oestradiol microimplants in the ventromedial preoptic area inhibit secretion of luteinizing hormone via dopamine neurones in anoestrous ewes. J Neuroendocrinol 13:1051-1058

21. Stojilkovic SS, Izumi S, Catt KJ 1988 Participation of voltage-sensitive calcium channels in pituitary hormone release. J Biol Chem 263:13054-13061

22. Calo G, Bigoni R, Rizzi A, Guerrini R, Salvadori S, Regoli D 2000 Nociceptin/orphanin FQ receptor ligands. Peptides 21:935-947

23. Dhandapani KM, Brann DW 2002 Orphanin FQ inhibits GnRH secretion from rat hypothalamic fragments but not GT1-7 neurons. Neuroreport 13:1247-1249

24. Moss GE, Nett TM 1980 GnRH interaction with anterior pituitary. IV. Effect of estradiol-17 beta on GnRH-mediated release of LH from ovine pituitary cells obtained during the breeding season, anestrous season, and period of transition into or out of the breeding season. Biol Reprod 23:398-403

25. Whisnant CS, Goodman RL 1988 Effects of an opioid antagonist on pulsatile luteinizing hormone secretion in the ewe vary with changes in steroid negative feedback. Biol Reprod 39:1032-1038

26. Moenter SM, Caraty A, Karsch FJ 1990 The estradiol-induced surge of gonadotropin-releasing hormone in the ewe. Endocrinology 127:1375-1384

27. Caraty A, Locatelli A, Schanbacher B 1987 Augmentation, by naloxone, of the frequency and amplitude of LH-RH pulses in hypothalamo-hypophyseal portal blood in the castrated ram. C R Acad Sci III 305:369-374 
28. Devine DP, Taylor L, Reinscheid RK, Monsma FJ, Jr., Civelli O, Akil H 1996 Rats rapidly develop tolerance to the locomotor-inhibiting effects of the novel neuropeptide orphanin FQ. Neurochem Res 21:1387-1396

29. Berger H, Bigoni R, Albrecht E, Richter RM, Krause E, Bienert M, Calo G 2000 The nociceptin/orphanin FQ receptor ligand acetyl-RYYRIK-amide exhibits antagonistic and agonistic properties. Peptides 21:1131-1139

30. Neal CR, Jr., Mansour A, Reinscheid R, Nothacker HP, Civelli O, Akil H, Watson SJ, Jr. 1999 Opioid receptor-like (ORL1) receptor distribution in the rat central nervous system: comparison of ORL1 receptor mRNA expression with (125)I-[(14)Tyr]-orphanin FQ binding. J Comp Neurol 412:563-605

31. Foradori CD 2004 The Orphanin FQ Receptor, Opioid Receptor Like-1, is Expressed in the GT1-7 Cells and Pituitary. Society for Neurosciency, Washington, D.C., 2004

32. Moenter SM, Brand RM, Midgley AR, Karsch FJ 1992 Dynamics of gonadotropin-releasing hormone release during a pulse. Endocrinology 130:503-510

33. Smith JT, Ross Young I, Veldhuis JD, Clarke IJ 2012 Gonadotropin-Inhibitory Hormone (GnIH) Secretion into the Ovine Hypophyseal Portal System. Endocrinology 153:3368-3375

34. Wagner EJ, Ronnekleiv OK, Grandy DK, Kelly MJ 1998 The peptide orphanin FQ inhibits beta-endorphin neurons and neurosecretory cells in the hypothalamic arcuate nucleus by activating an inwardly-rectifying K+ conductance. Neuroendocrinology 67:73-82

35. Lehman MN 2011 Orphanin FQ cells of the ovine hypothalamus express estradiol receptor-alpha and progesterone receptors, but not kisspeptin or tyrosine hydroxylase. Society for the Study of Reproduction, Portland, OR, 2011 


\section{FIGURE LEGENDS}

Figure 1. Mean LH concentration $( \pm$ SEM $)$ from adult ewe $(n=4)$ anterior pituitary cells with increasing doses of OFQ (Panel A) followed by $\mathrm{KCl}$ treatment (Panel B).

Figure 2. Mean LH concentration $( \pm$ SEM) from adult ewe $(n=8)$ anterior pituitary cells treated with increasing doses of GnRH with or without OFQ (Panel A) followed by $\mathrm{KCl}$ treatment (Panel B). No OFQ (white bars), 550 pmol OFQ (grey bars), and 5500 pmol OFQ (black bars). Significance ( $<<0.05)$ between $\mathrm{GnRH}$ treatment groups is indicated by differing superscripts.

Figure 3. Secretory profiles of LH (top) and GnRH (bottom) from OVX ewes for 4 hrs before and during 4 hrs of either saline (Panel A) or OFQ agonist ([Arg14,Lys15] OFQ; Panel B) infusion. LH and GnRH pulses are identified by closed symbols. Infusion time is indicated by solid grey (saline) or solid black (OFQ agonist) bar.

Figure 4. Mean LH concentration $( \pm$ SEM; Panel A) and mean GnRH concentration ( \pm SEM; Panel B) for saline infused OVX ewes $(n=5)$. Mean LH $( \pm$ SEM; Panel C) and mean GnRH $( \pm$ SEM; Panel D) concentration for OFQ agonist, [Arg14,Lys15] OFQ, infused OVX ewes $(n=5)$. Measurements prior to infusion are represented by open bars. Significance $(\mathrm{p}<0.05)$ within treatment group is indicated by differing superscripts.

Figure 5. Mean LH pulse amplitude ( \pm SEM; Panel A) and mean GnRH pulse amplitude $( \pm$ SEM; Panel B) for saline infused OVX ewes $(n=5)$. Mean LH pulse amplitude $( \pm$ SEM; Panel C) and mean GnRH pulse amplitude ( \pm SEM; Panel D) for OFQ agonist, [Arg14,Lys15] OFQ, infused OVX ewes ( $\mathrm{n}=5)$. Measurements prior to infusion are represented by open bars. Significance $(p<0.05)$ within treatment group is indicated by differing superscripts.

Figure 6. Mean LH pulse frequency $( \pm$ SEM; Panel A) and mean GnRH pulse frequency $( \pm$ SEM; Panel B) for saline infused OVX ewes $(n=5)$. Mean LH pulse amplitude $( \pm$ SEM; Panel C) and mean GnRH pulse frequency ( \pm SEM; Panel D) for OFQ agonist, [Arg14,Lys15] OFQ, infused OVX ewes $(n=5)$. Measurements prior to infusion are represented by open bars. Significance $(p<0.05)$ within treatment group is indicated by differing superscripts. 
Figure 7. Mean GnRH baseline $( \pm$ SEM) for OVX ewes ( $n=5 /$ group) with infusion of saline (gray bars) or OFQ agonist ([Arg14Lys15] OFQ; black bars). Measurements prior to infusion measurements are represented by open bars. Significance $(\mathrm{p}<0.05)$ within treatment group is indicated by differing superscripts. 


\section{FIGURES}

Figure 1

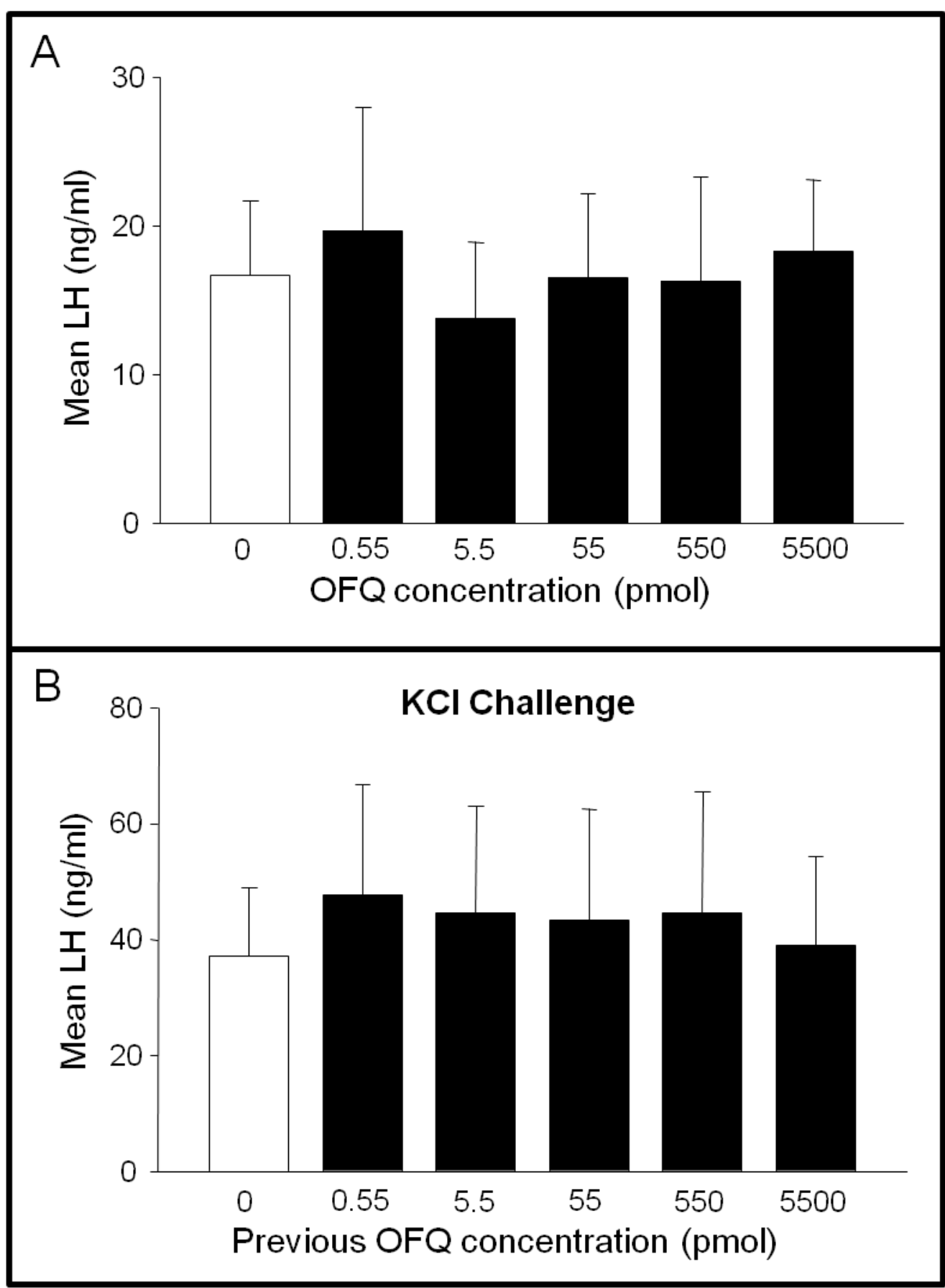


Figure 2

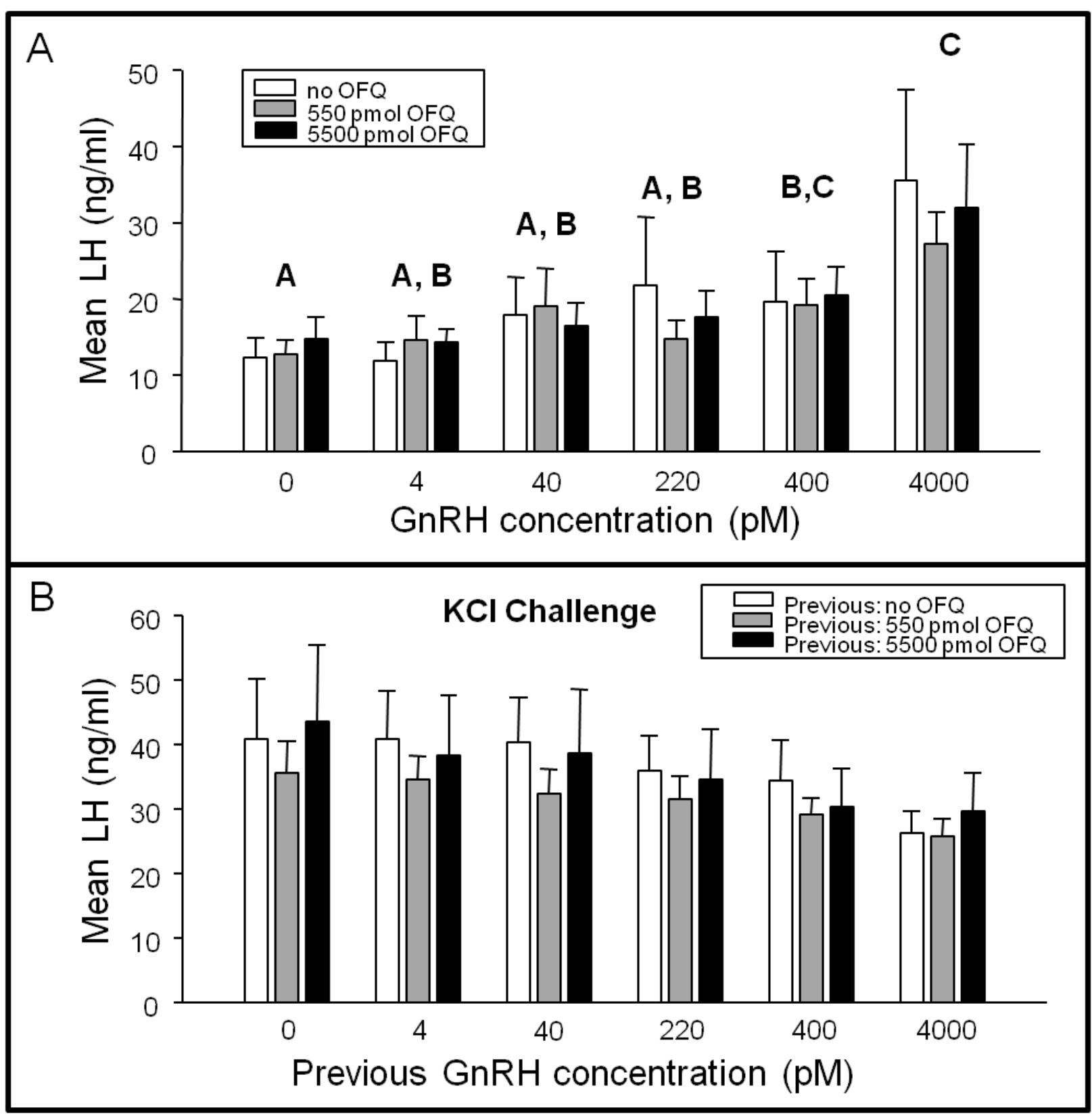


Figure 3

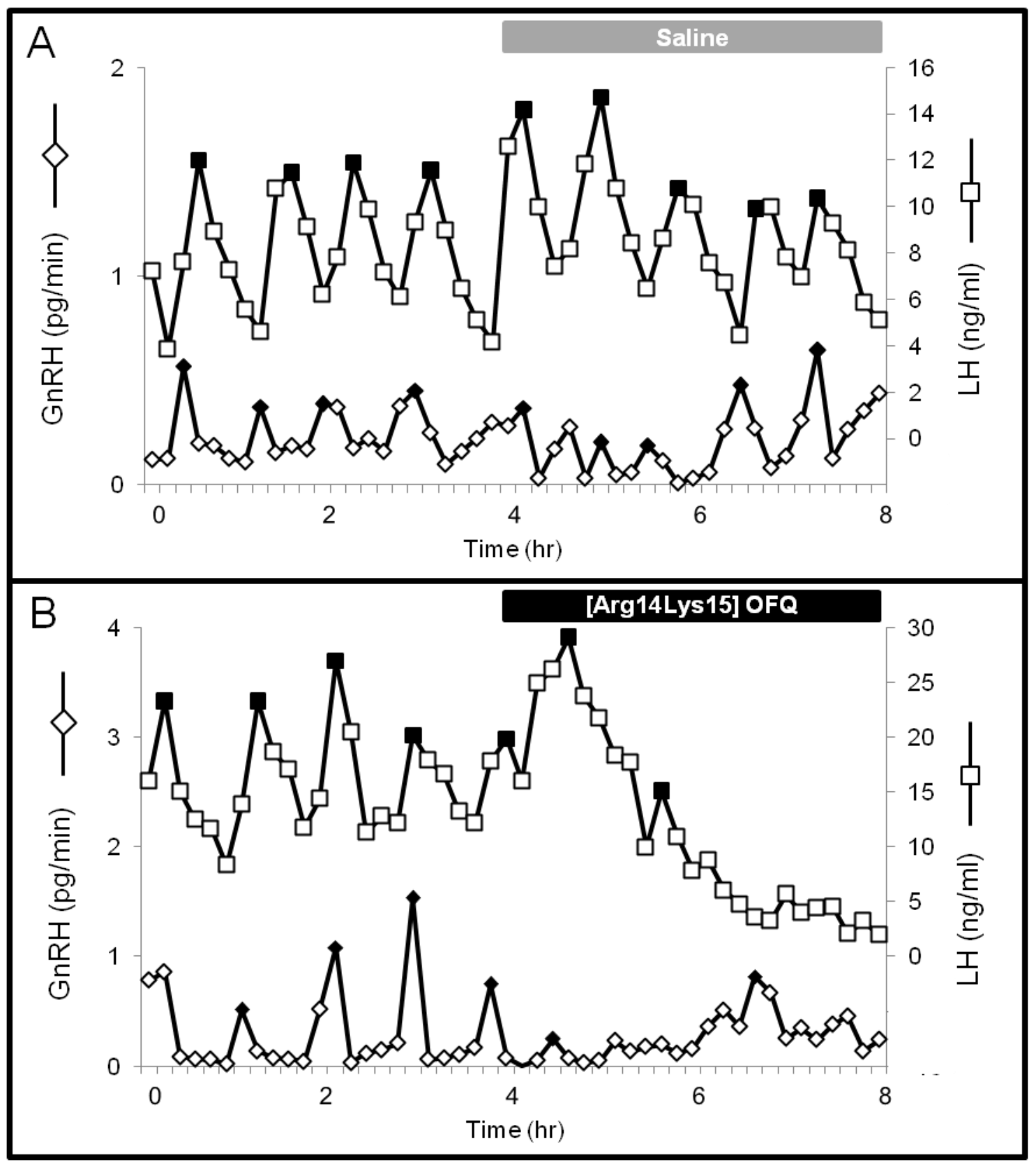


Figure 4

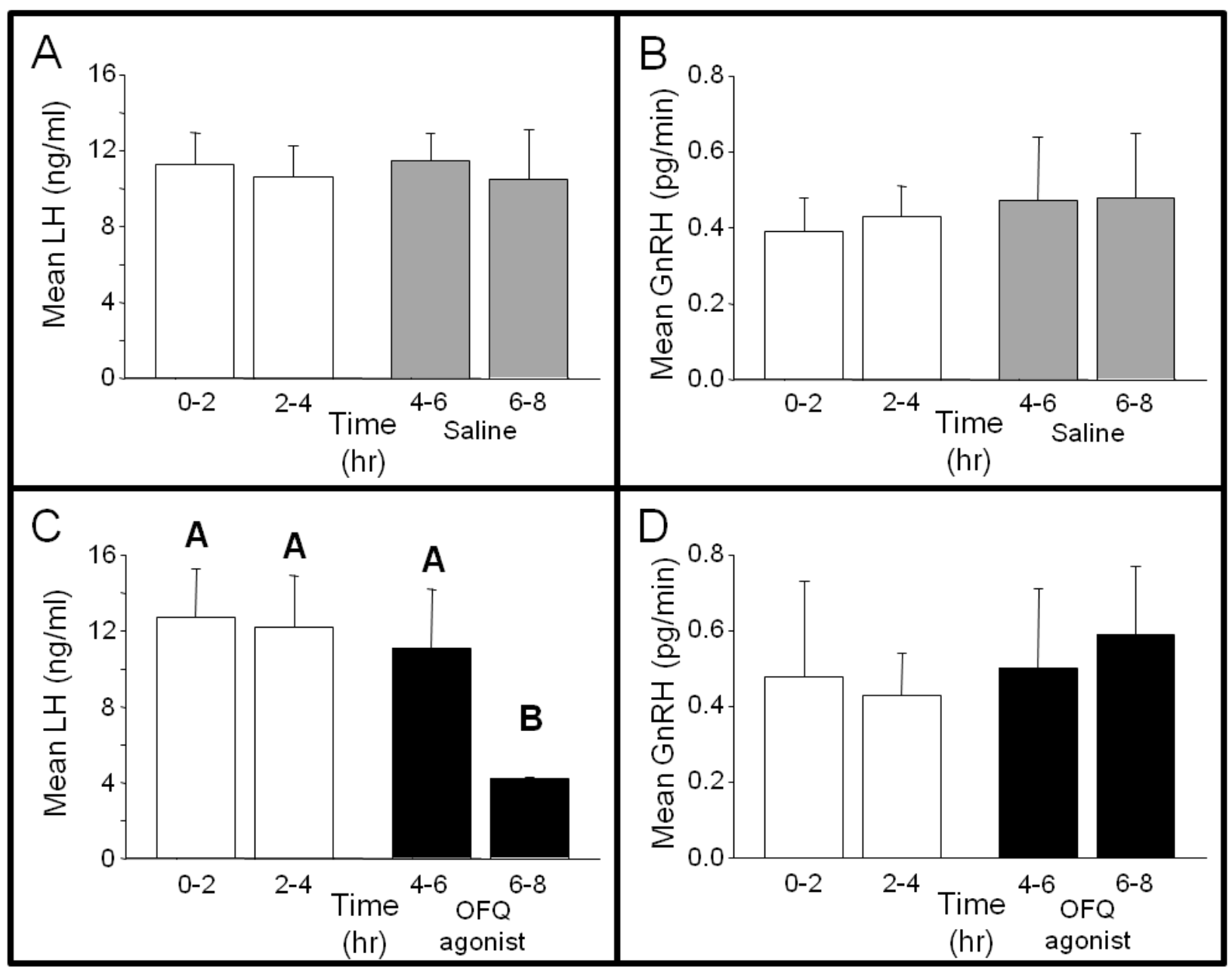


Figure 5

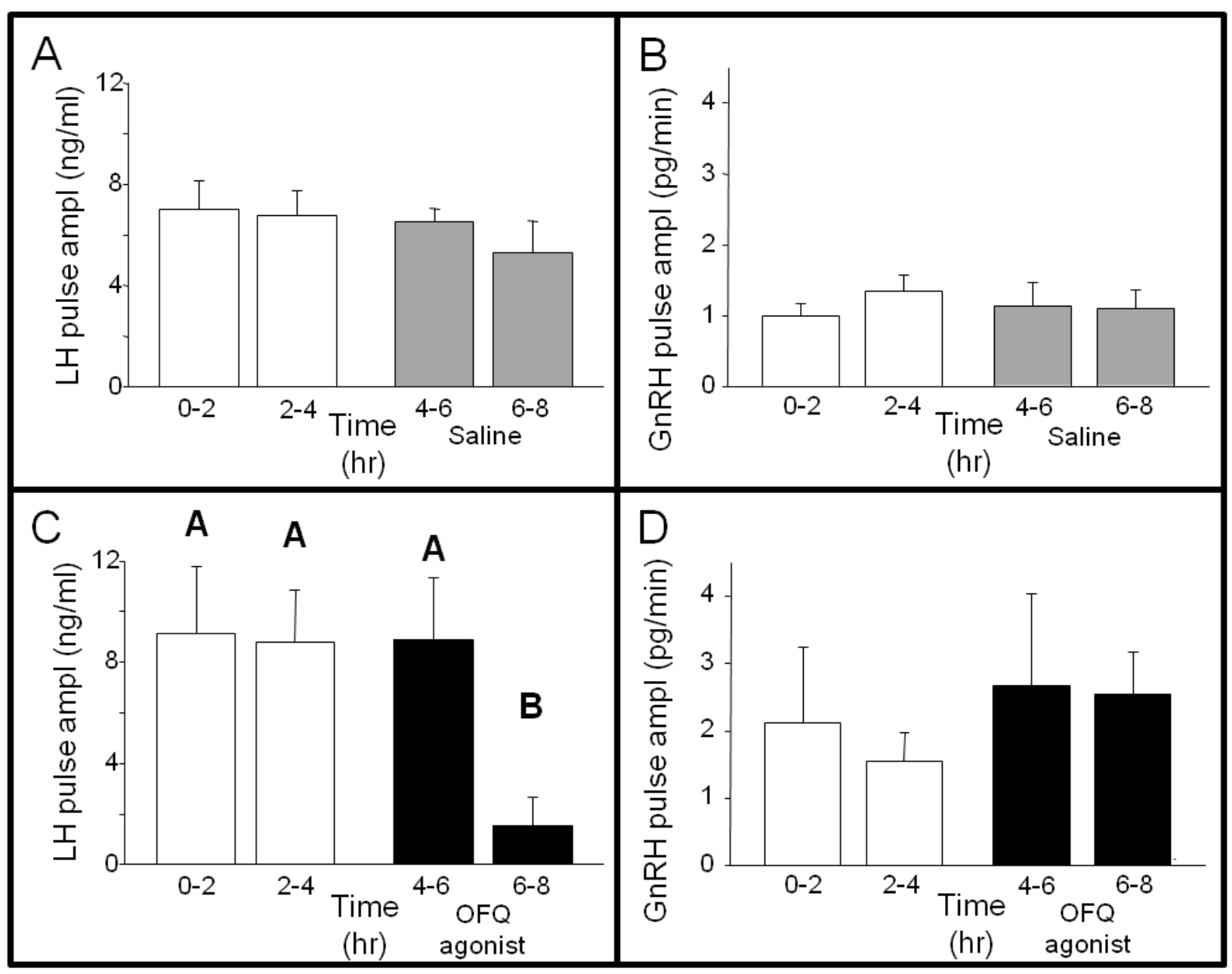


Figure 6

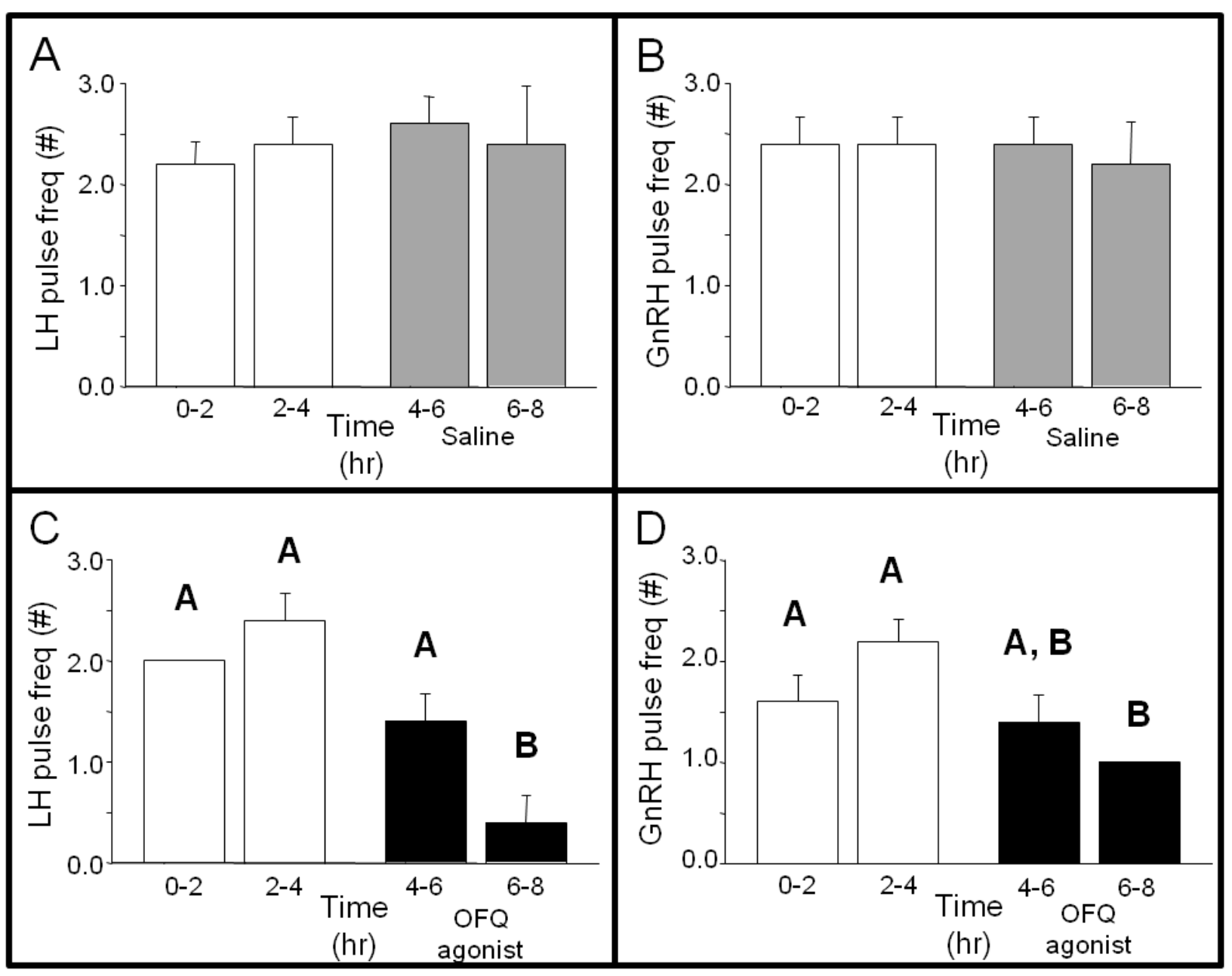


Figure 7

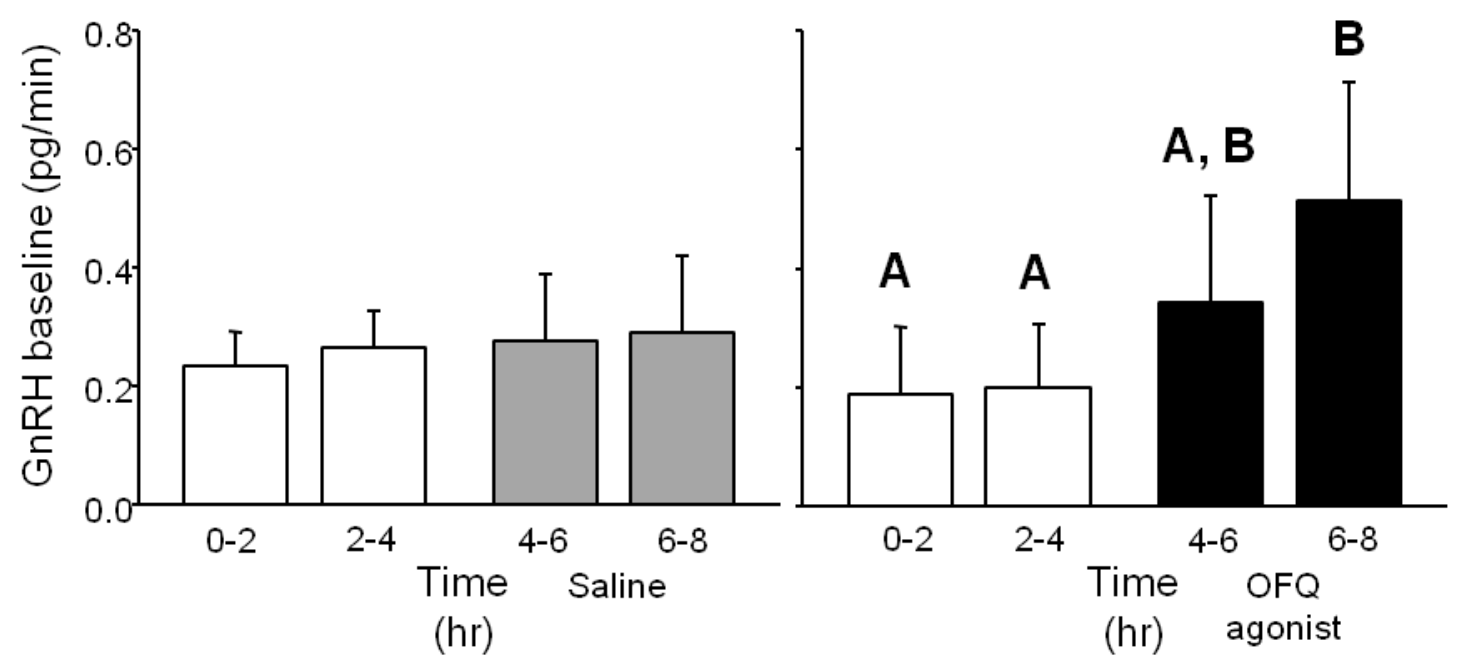




\section{CHAPTER 4}

Evidence that Orphanin FQ Mediates Progesterone Negative Feedback in the Ewe.

Nestor $\mathrm{CC}^{1}$, Cheng $\mathrm{G}^{2}$, Nesselrod $\mathrm{GL}^{1}$, Valent $\mathrm{M}^{1}$, Connors $\mathrm{JM}^{1}$, Hileman $\mathrm{SM}^{1}$, Coolen $\mathrm{LM}^{2}$, Lehman $\mathrm{MN}^{2}$, Goodman $\mathrm{RL}^{1}$

${ }^{1}$ Department of Physiology and Pharmacology School of Medicine

West Virginia University, Morgantown WV 26506

${ }^{2}$ Departments of Molecular and Integrative Physiology, and Obstetrics \& Gynecology, University of Michigan, Ann Arbor, MI

Running Heading: OFQ mediates progesterone negative feedback in sheep 


\section{ABSTRACT}

Gonadotropin-releasing hormone $(\mathrm{GnRH})$ neurons are the final common pathway for neuroendocrine control of the reproductive axis. During the estrous cycle of the ewe, episodic release of GnRH, and subsequently luteinizing hormone ( $\mathrm{LH})$, is under the control of steroid negative feedback. Since GnRH neurons are devoid of the appropriate steroid receptors, this feedback must occur indirectly through input from other neurons. Neurons that release orphanin FQ (OFQ), a member of the opioid family, may be involved. OFQ has been shown to exist within many areas of the hypothalamus and when given centrally OFQ inhibits episodic LH secretion in ovariectomized sheep. Based on these data, we hypothesized that OFQ mediates the inhibitory effects of estradiol and/or progesterone. To test our hypothesis we examined OFQ neurons in the preoptic area (POA) and hypothalamus of luteal phase ewes for colocalization with estrogen receptor- $\alpha(\mathrm{ER} \alpha)$ and progesterone receptor. Furthermore, we examined if OFQ neurons in the arcuate nucleus (ARC) contain other neuropeptides. POA OFQ neurons did not contain ER $\alpha$ or progesterone receptors, while in contrast, a majority of OFQ neurons in the ARC contained both ER $\alpha$ and progesterone receptors. In addition, 50\% of arcuate POMC neurons contained OFQ, but OFQ did not colocalize with kisspeptin, tyrosine hydroxylase or agouti-related peptide (AgRP). To test a role for endogenous OFQ, we examined the effects of an OFQ receptor antagonist, UFP-101, on LH secretion in steroid treated ewes in the breeding and non-breeding season. During the breeding season, eight adult ewes were ovariectomized and had a chronic guide tube inserted into the lateral ventricle. Ewes also received a $1 \mathrm{~cm}$ long estradiol implant and 2 progesterone packets $\mathrm{sc}$ at the time of surgery. Following a recovery period of 10 days, we infused UFP-101 (30 nmole/hr) or saline (120 $\mu \mathrm{l} / \mathrm{hr})$ into the lateral ventricle and collected blood samples every $12 \mathrm{~min}$ via a jugular catheter for $6 \mathrm{hr}$. Treatments of either saline or antagonist were delivered to all sheep at random with three days between treatments.

Progesterone packets were removed and treatments were repeated in a similar manner ten days later in ewes treated only with the sc estradiol implant with blood samples collected every $12 \mathrm{~min}$ for $5 \mathrm{hr}$. During the non-breeding season, six ovary-intact ewes received a chronic guide tube into the lateral ventricle. Following surgical recovery ewes were treated with saline or OFQ receptor antagonist at 
random with three days between treatments with blood samples collected every $12 \min$ for $4 \mathrm{hr}$. Ewes with luteal phase concentrations of progesterone showed a significant increase in LH pulse frequency during infusion of UFP-101 (4.5 \pm 0.5 pulses/6hr) compared to saline infusion (2.6 $\pm 0.4 \mathrm{pulses} / 6 \mathrm{hr})$. Ewes implanted with only estradiol or steroid intact anestrous ewes displayed no significant difference in LH pulse amplitude or frequency during infusion of UFP-101. Therefore, we conclude that OFQ mediates, at least in part, the negative feedback action of progesterone on GnRH/LH secretion in sheep. 


\section{INTRODUCTION}

Gonadotropin-releasing hormone $(\mathrm{GnRH})$ is the final neural pathway controlling luteinizing hormone (LH) secretion from the gonadotropes of the anterior pituitary. GnRH secretion is predominantly episodic and the amplitude and frequency of GnRH pulses are under steroid negative feedback from the ovary. During the estrous cycle in sheep, estradiol $\left(\mathrm{E}_{2}\right)$ inhibits $\mathrm{GnRH}$ pulse amplitude $(1,2)$, while progesterone suppresses GnRH pulse frequency $(3,4)$. The simplest explanation for control by ovarian steroids would be a direct inhibition of GnRH neurons, but GnRH neurons possess neither estrogen receptor- $\alpha(\mathrm{ER} \alpha)(5$, 6) or progesterone receptor (PR) (7). Therefore, inhibition of GnRH release by estradiol and progesterone is mediated via afferent neurons that have yet to be completely identified.

Considerable work has implicated endogenous opioid peptides (EOP) in the negative feedback control of GnRH secretion in sheep. Infusion of an opioid antagonist increases LH pulse amplitude during the follicular phase and in estradiol-treated OVX ewes (8). However, the antagonist-induced increase in $\mathrm{GnRH}$ pulse amplitude is independent of $\mathrm{E}_{2}(2)$, so it is unlikely that EOP mediate this effect of $E_{2}$ in ewes. In luteal phase ewes, an opioid antagonist increases $\mathrm{GnRH}$ pulse frequency in hypophyseal portal blood (9). Furthermore, administration of an EOP antagonist increases LH pulse frequency during the luteal phase and in progesterone-treated ovariectomized (OVX) ewes. The EOP dynorphin appears to mediate progesterone negative feedback for three reasons. One, greater than $90 \%$ of dynorphin neurons contain PR (10). Two, progesterone has been shown to stimulate dynorphin expression and release (11). Lastly, administration of a kappa receptor antagonist increases LH pulse frequency in luteal phase ewes (12). However, recent results raise the possibility that other neuronal systems may also play a role in progesterone negative feedback in the ewe (13).

Another EOP that could play a role in steroid negative feedback is orphanin FQ (OFQ). OFQ, also known as nociceptin, was discovered by two independent groups and binds to a G-coupled protein receptor, opioid receptor like-1 (ORL-1), that is not affected by classical EOP receptor antagonists (14,

15). OFQ and ORL-1 are found throughout the hypothalamus in rats $(16,17)$, humans (18) and sheep (19). In the ewe, greater than $90 \%$ of OFQ neurons in the preoptic area (POA) colocalize with GnRH, but 
OFQ neurons not containing GnRH are present within the hypothalamus (19). Given its location, and because we (19) and others $(20,21)$ have shown that OFQ can inhibit LH secretion in vivo, we hypothesize that OFQ neurons contain ER $\alpha$ and PR and mediate steroid negative feedback in the ewe. To test this hypothesis, we used immunocytochemistry to examine whether OFQ neurons in the POA and hypothalamus of the ewe contain ER $\alpha$ and/or PR. Furthermore, given the high degree of steroid receptor colocalization with OFQ in the arcuate nucleus (ARC), we examined whether or not OFQ colocalized with other neuropeptides known to be found in steroid receptors-containing neurons in the ARC using dual immunofluorescence. Finally, to test a role for endogenous OFQ, we examined LH secretion following administration of an OFQ receptor antagonist in OVX ewes receiving progesterone and estradiol $\left(\mathrm{P}+\mathrm{E}_{2}\right)$ or $\mathrm{E}_{2}$ alone during the breeding season and in ovary-intact ewes during the non-breeding season.

\section{MATERIALS AND METHODS}

\section{Animals}

Adult ewes (> 3yrs) of mixed-breeding were housed indoors with lighting that simulated natural daylength and received a diet of alfalfa pellets with water ad libitum. Breeding season experiments were done with ewes showing regular estrous cycles (based on estrous detection with a vasectomized ram) between October and February; anestrous experiments were done in May. Reproductive status for anestrous ewes was confirmed by inspection of the ovaries for the absence of corpora lutea on the day of sacrifice. For blood collection, jugular catheters were inserted the day before blood samples ( $3 \mathrm{ml})$ were taken; blood was collected into heparinized tubes and plasma was stored at $-20^{\circ} \mathrm{C}$. All procedures were approved by the West Virginia University Animal Care and Use Committee and followed NIH guidelines for use of animals in research.

\section{Reagents}

Antibodies: Rabbit antiserum against OFQ was obtained from Neuromics (Edina, MN) and mouse antisera against ER $\alpha$ and PR were purchased from DAKO (Carpinteria, CA) and Beckman Coulter/Immunotech (Brea, CA), respectively. Rabbit antiserum against proopiomelanocortin (POMC) 
was purchased from Phoenix Pharmaceuticals, Inc. (Burlingame, CA), guinea pig antisera against mouse agouti-related peptide (AgRP) was obtained from Antibodies Australia (Melbourne, Australia), mouse antiserum against tyrosine hydroxylase (TH) was purchased from Millipore (Billerica, MA), and rabbit antiserum against kisspeptin was a gift from A. Caraty (Nouzilly, France). All of these antibodies have been validated for use in sheep $(19,22-25)$. In addition, omission of one or both primary antibodies and preabsorption with purified antigens served as controls (data not shown) in experiments 1 and 2.

ORL-1 antagonists: UFP-101 and JTC-801 (Tocris Bioscience, Ellisville, MO) were stored as recommended by the manufacturer and diluted to $250 \mathrm{nmoles} / \mathrm{ml}$ in $0.9 \%$ sterile saline the day before infusions.

\section{Surgical Procedures}

All procedures were performed using sterile technique under gas anesthesia (oxygen $+3 \%$ isoflurane). Ovariectomies (OVX) were performed by midventral laparotomy and a chronic lateral cerebroventricle cannula was inserted using a modification of our standard neurosurgical approach (26). After exposure of the top of the skull, an initial mark was positioned $5 \mathrm{~mm}$ rostral and $3.5 \mathrm{~mm}$ lateral to bregma after which a $1 \mathrm{~cm}$ hole was drilled at this mark to expose the dura. Four stainless steel screws were inserted in the skull surrounding the hole in order to anchor the dental acrylic. A small hole was burned in the exposed dura by brief cauterization, and a 16 gauge needle, that had been cut to a length of 1.25 inches and equipped with detachable tubing filled with sterile water, was lowered into the brain until the ventricle was pierced and flow was observed (depth of 18-22 mm). Then $1 \mathrm{ml}$ of a radio-opaque dye, Omnipaque 350 (Iohexol; Winthrop, NY), was slowly injected and the dorsal/ventral position of the needled adjusted to the middle of the lateral ventricle, if necessary, based on a lateral X-ray. The needle hub was plugged to prevent loss of cerebrospinal fluid and was covered with a plastic protective cap cemented in place using dental acrylic. All ewes were treated pre- and post-operatively with Penicillin Procaine G (Webster Veterinary Supply), Dexamethosone (Webster Veterinary Supply), and FluMeglumine (Webster Veterinary Supply) as previously described (26) and allowed at least 10 days for recovery.

\section{Tissue Collection and Processing}


Tissue for immunocytochemistry was collected as described previously (27). Briefly, ewes (n=3) in the mid-luteal phase of the estrous cycle were heparinized (20,000 U) and killed using an iv overdose of sodium pentabarbitol (Euthasol, Webster Veterinary, Devens, MA). Heads were removed and perfused via the carotid arteries with four liters of $2 \%$ paraformaldehyde in $0.1 \mathrm{M}$ phosphate buffer $(\mathrm{PB}, \mathrm{pH}=7.4)$ containing $0.1 \%$ sodium nitrite. Blocks of tissue containing the POA and the hypothalamus were then removed and stored in $2 \%$ paraformaldehyde for $24 \mathrm{hrs}$ at $4^{\circ} \mathrm{C}$ and transferred to $20 \%$ sucrose until sectioned. Frozen coronal sections $(40 \mu \mathrm{m})$ were cut with a freezing microtome and stored in cryopreservative until the time of immunocytochemical staining.

\section{Experiment 1: Colocalization of OFQ with ER $\alpha$ or PR.}

Dual- immunocytochemistry for OFQ and ER $\alpha$ or PR was done in free floating sections as previously described $(19,25,28)$; all incubations were at room temperature. On Day 1, a series of every sixth section from the POA through the ARC was washed $12 \times 15$ min in $0.1 \mathrm{M}$ phosphate buffered saline (PBS) and then placed in $1 \% \mathrm{H}_{2} \mathrm{O}_{2}$ for 10 min followed by $4 \times 5$ min washes in PBS. Tissue was then incubated for $1 \mathrm{hr}$ with $0.4 \%$ Triton-X (Sigma-Aldrich, St. Louis, MO) in 20\% normal goat serum (NGS) in PBS and then incubated with 1:1000 ER $\alpha$ antiserum or 1:50 PR antiserum for $17 \mathrm{hrs}$ and $40 \mathrm{hrs}$, respectively. Thereafter, tissue was rinsed with PBS 4x5 min and biotinylated goat anti-mouse antibody (Vector Laboratories, Burlingame, CA) at 1:500 and Vectastain ABC-elite (Vector Laboratories) at 1:500, both in $0.4 \%$ Triton-X in $4 \%$ NGS, were applied sequentially for $1 \mathrm{hr}$ each with $4 \times 5$ min washes of PBS between incubations. Sections were then placed in a 3, 3'-diaminobenzidine tetrahydrochloride (DAB)-nickel solution (10 mg DAB [Sigma-Aldrich] and $2 \mathrm{ml}$ of $2 \%$ nickel sulfate in $50 \mathrm{ml}$ PB with $20 \mu 130 \% \mathrm{H}_{2} \mathrm{O}_{2}$ added just before incubation) for $10 \mathrm{~min}$. Sections were washed in PBS 4x5 min and then incubated for $10 \mathrm{~min}$ in $1 \% \mathrm{H}_{2} \mathrm{O}_{2}$ followed by $4 \times 5$ min washes in PBS. After incubation for 40 hrs with 1:2500 OFQ antiserum in $0.4 \%$ Triton-X in $4 \%$ NGS, tissue was rinsed with PBS 4x5 min and biotinylated goat antirabbit antibody (Jackson ImmunoResearch, West Grove, PA) at 1:500 and Vectastain ABC-elite (Jackson ImmunoResearch) at 1:500, both in $0.4 \%$ Triton-X in $4 \%$ NGS, were applied sequentially for $1 \mathrm{hr}$ each 
with 4x5 min washes of PBS between incubations. Sections were then incubated in DAB without nickel enhancement, washed 4x5 min in PB, and mounted on Superfrost/Plus microscope slides (Fisher Scientific, Pittsburgh, PA). Sections were dehydrated using a series of increasing alcohol baths and coverslipped using DPX Mounting Medium (Electron Microscopy Sciences, Hatfield, PA).

\section{Experiment 2: Colocalization of OFQ with AgRP , TH, POMC and kisspeptin.}

When the primary antisera were of the same species, immunofluourescence was performed using biotin tyramide amplification and conjugated second antibody detection to visualize the first and second antigen, respectively (23), otherwise amplification was not needed. For AgRP and TH visualization with OFQ, a series of tissue sections from the middle ARC was washed in $0.1 \mathrm{M}$ PBS, incubated in $0.1 \%$ Triton-x containing $4 \%$ and $20 \%$ normal goat serum, respectively, followed by a $17 \mathrm{hr}$ incubation in PBS containing 4\% normal goat serum with rabbit anti-OFQ (1:2500) and guinea pig anti-AgRP (1:1000) or mouse anti-TH (1:2000) at room temperature. The next day after washing tissue 4x5 min in PBS (from here on tissue was covered with tin foil to prevent light exposure), secondary antibody for OFQ (goat anti-rabbit Alexa 555; 1:100) and AgRP (goat anti-guinea pig Alexa 488; 1:100) or TH (goat anti-mouse Alexa $488 ; 1: 100$ ) in $0.4 \%$ Triton-x and $4 \%$ normal goat serum in PBS was applied to tissue for one hour. For POMC and kisspeptin, a series of sections through the middle ARC was washed in $0.1 \mathrm{M}$ PBS, incubated in $0.4 \%$ Triton-x in $20 \%$ normal goat serum for an hour, followed by a $17 \mathrm{hr}$ incubation in rabbit anti-OFQ (1:20000) or rabbit anti-kisspeptin (1:200,000) at room temperature. The following day tissue was washed in $0.1 \mathrm{M}$ PBS $4 \times 5 \mathrm{~min}$, followed by one hour incubation in biotinylated goat anti-rabbit (1:500) in $0.4 \%$ Triton-x in 4\% normal goat serum in PBS. Tissue was washed $4 \times 5$ min followed by a 1 hr incubation in ABC-elite solution (1:500) for $1 \mathrm{hr}$, then washed 4x5 min in PBS. Tissue was then incubated in biotinylated tyramine (1:250) for 10 min followed by $4 \times 5$ min washes in PBS. Then Alexa 555-streptavidin (red; 1:100 for OFQ) or Alexa 488-streptavidin (green; 1:100 for kisspeptin) in PBS. Tissue was then washed 4x5 min in PBS followed by a 17 hour incubation with rabbit anti-POMC (1:16000) or rabbit anti-OFQ $(1: 1000)$ in $0.4 \%$ Triton-x with $4 \%$ normal goat serum containing PBS. The following day tissue was washed 4x5 min in PBS and then incubated with goat anti-rabbit Alexa 488 
(green; 1:100 for POMC) or goat anti-rabbit Alexa 555 (red; 1:100 for OFQ) in 0.4\% Triton-x with 4\% normal goat serum containing PBS for $30 \mathrm{~min}$. After a final wash $4 \times 5 \mathrm{~min}$ in PBS, all tissue was mounted on glass slides, coverslipped using Gelvatol mounting medium and stored in the dark at 4C.

\section{Experiment 3a: Effects of ORL-1 antagonists in $\mathrm{OVX}+\mathrm{P}+\mathrm{E}_{2}$ ewes.}

Eight breeding season ewes were OVX and a guide tube was inserted into one lateral ventricle. At the time of OVX, ewes were given a $1 \mathrm{~cm} \mathrm{E}_{2}$ implant sc (29) and two progesterone packets sc (30). Starting approximately two weeks later, ewes received a lateral ventricle infusion of $0.9 \%$ saline $(120 \mu \mathrm{l} / \mathrm{hr})$, UFP101 (30 nmoles/hr), or JTC-801 (30 nmoles/hr). Doses of antagonists were based on data from preliminary experiments (data not shown). The day before infusion, one jugular vein was catheterized and ewes were placed in a narrow pen so that they could lie down, but not turn around; an infusion line was inserted just before the start of blood collections that extended from the tip of the guide tube to a portable microinfusion pump strapped to the back of each animal. Blood was collected every 12 min for $6 \mathrm{hrs}$ with infusion starting immediately prior to and continuing throughout the collection period. Each ewe received all three treatments in random order, separated by 3 days between each treatment. Gentamicin (Webster Veterinary Supply; Devens, MA) was given im prophylactically at the end of each icv infusion.

\section{Exp 3b: Effects of an ORL-1 antagonist in $\mathrm{OVX}+\mathrm{E}_{2}$ ewes.}

At the end of experiment $3 \mathrm{a}$, progesterone packets were removed, but $\mathrm{E}_{2}$ implants were left in place. Two weeks later, all sheep received a lateral ventricle infusion of saline (120 $\mu \mathrm{l} / \mathrm{hr})$ or UFP-101 (30 nmoles/hr) with 3 days between treatments in a crossover design. Since results did not differ between antagonists, we chose to only administer UFP-101 for experiment 3b. Blood samples were collected every 12 min for $5 \mathrm{hr}$ with infusion starting immediately prior to and continuing throughout the collection period.

\section{Exp 4: Effects of an ORL-1 antagonist in ovary-intact, anestrous ewes.}

Starting approximately two weeks after insertion of a lateral ventricle guide tube, 6 ovary-intact, anestrous ewes were infused with saline (120 $\mu \mathrm{l} / \mathrm{hr})$ or UFP-101 (30 nmoles/hr), into the lateral ventricle 
with 3 days between treatments in a crossover design. Blood samples were collected every 12 min for 4 hrs with infusion starting immediately prior to and continuing throughout the collection period.

\section{Data Analysis}

Immunocytochemistry: Hemisections from a series of every sixth section from the POA and hypothalamus were used for immunocytochemical detection of OFQ, ER $\alpha$ and PR. OFQ was visualized using unenhanced DAB as the chromogen (brown reaction product), while ER $\alpha$ and PR were visualized using nickel-enhanced DAB (blue-black reaction product). Dual-labeled cells were defined as those in which a blue-black nucleus was surrounded by a brown cytoplasm as seen in the same plane of focus. Immunopositive cells were counted manually using a light microscope. A series of sections through the middle ARC was used for immunfluourecent detection of OFQ with AgRP, TH, POMC or kisspeptin. Immunoflurescent cells were visualized by confocal z-stacks of $1 \mu \mathrm{m}$ thick optical sections and were captured using a Zeiss LSM 510 (Hornwood, NY) confocal microscope at 63x magnification. Assays: LH concentrations were measured as previously described (Whisnant and Goodman, 1988) in duplicate with a RIA using 100-200 $\mu$ l of plasma and reagents provided by the National Hormone and Peptide Program (Torrance, CA). LH assay sensitivity averaged 0.12 ng/tube (NIH S24) with intra- and interassay coefficients of variation being $15.6 \%$ and $28.9 \%$, respectively.

Statistics: Pulses were identified using previously described criteria (Goodman and Karsch, 1980) and pulse frequency, pulse amplitude, and mean LH concentrations determined for each treatment period. Pulse frequency for Exp 3a was analyzed using Friedman Repeated Measures Analysis of Variance on Ranks. Pulse frequency for Exp $3 b$ and 4 was analyzed using Wilcoxon signed ranks test. Mean LH and LH pulse amplitude were analyzed using a one-way ANOVA in Exp 3a. A paired t-test was used to analyze mean LH and LH pulse amplitude in experiments $3 b$ and 4. Differences were considered to be significant at $\mathrm{p}<0.05$.

\section{RESULTS}

Experiment 1: Do OFQ neurons in the ovince hypothalamus possess ERa or PR? 
OFQ, ER $\alpha$, or PR immunoreactivity was examined in several hypothalamic areas and the POA as previously described $(6,7,19)$. OFQ immunoreactive cells were seen in all areas examined with the most dense staining occuring in the POA, periventricular nucleus, anterior hypothalamic area (AHA) and rostral to middle ARC (Fig 1A, B, and C). ERa (Fig 1A, B, and D) and PR (Fig 2A, B, and D) immunoreactive nuclei were seen in all areas examined with the greatest density in the POA. In the rostral, middle, and caudal levels of the ARC, between 80-100\% of OFQ cells colocalized ER $\alpha$ (Fig 1E), and $60-80 \%$ colocalized PR (Fig 2E). In the AHA, 75\% of OFQ positive cells coexpressed ER $\alpha$ (Fig 1E) while $60 \%$ coexpressed PR (Fig 2E). In the ventromedial nucleus, $30 \%$ and $44 \%$ of OFQ positive cells contained ER $\alpha$ (Fig 1E) and PR (Fig 2E), respectively. In contrast, less than $2 \%$ of OFQ cells in the POA or PVN colocalized ER $\alpha$ or PR.

\section{Experiment 2: Does OFQ colocalize with POMC, kisspeptin, AgRP or TH in the ARC of sheep?}

Since the highest percent colocalization of OFQ and ER $\alpha / \mathrm{PR}$ was within the ARC, we tested the hypothesis that OFQ would colocalize with other ARC neuropeptides. Approximately 50\% of POMC neurons in the middle ARC also contain OFQ (Fig 3A-C). OFQ did not colocalize with kisspeptin (Fig 3D), AgRP (Fig 3E) or TH (Fig 3F) in the ovine ARC.

Experiment 3a: Can infusion of $\mathrm{OFQ}$ receptor antagonists increase $\mathrm{LH}$ secretion in $\mathrm{OVX}+\mathrm{P}+\mathrm{E}_{2}$ ewes?

Given that OFQ can inhibit LH secretion in OVX ewes (Foradori et al., 2007), we tested the hypothesis that infusion of an OFQ receptor antagonist increases LH secretion in OVX ewes treated with with luteal phase concentrations of progesterone and $\mathrm{E}_{2}$. Figure 4 displays the pulse profiles from one ewe that received saline (Fig 4A), UFP-101 (Fig 4B) and JTC-801 (Fig 4C). Mean LH (Fig 5A) and LH pulse amplitude (Fig 5B) were not significantly increased with infusion of UFP-101 $(1.93 \pm 0.22$ and $1.28 \pm$ $0.21 \mathrm{ng} / \mathrm{ml}$, respectively) or JTC-801 (2.26 \pm 0.37 and $1.30 \pm 0.22 \mathrm{ng} / \mathrm{ml}$, respectively) compared with saline infusion $(2.00 \pm 0.50$ and $1.01 \pm 0.17 \mathrm{ng} / \mathrm{ml}$, respectively). LH pulse frequency (Fig 5C) for UFP$101(4.50 \pm 0.53$ pulses $/ 6 \mathrm{hrs})$ and JTC-801 (4.86 \pm 0.28 pulses/6hrs $)$ was significantly increased compared to infusion of saline $(2.62 \pm .40$ pulses $/ 6 \mathrm{hrs})$. 


\section{Experiment 3b: Does UFP-101 increase LH secretion in $\mathrm{OVX}+\mathrm{E}_{2}$ ewes?}

Since we observed similar results with UFP-101 and JTC-801 in experiment 3a, we conducted experiment $3 \mathrm{~b}$ and 4 using only UFP-101. OVX+ $\mathrm{E}_{2}$ ewes infused with UFP-101 did not differ significantly from saline-infused $\mathrm{OVX}+\mathrm{E}_{2}$ ewes with regard to mean LH (Fig 6A; $4.06 \pm 0.62 \mathrm{ng} / \mathrm{ml}$ and $5.14 \pm 0.69 \mathrm{ng} / \mathrm{ml}$, respectively), $\mathrm{LH}$ pulse amplitude (Fig 6B; $3.82 \pm 1.11 \mathrm{ng} / \mathrm{ml}$ and $3.03 \pm 1.01 \mathrm{ng} / \mathrm{ml}$, respectively) or $\mathrm{LH}$ pulse frequency (Fig 6C; $4.12 \pm 0.24$ pulses $/ 5 \mathrm{hrs}$ and $3.25 \pm 0.56$ pulses $/ 5 \mathrm{hrs}$, respectively).

\section{Experiment 4: Does UFP-101 increase LH secretion in ovary-intact anestrous ewes?}

In ovary-intact anestrous ewes, mean LH (Fig 7A) during infusion of UFP-101 $(1.86 \pm 0.37 \mathrm{ng} / \mathrm{ml}) \mathrm{did}$ not differ significantly from that during infusion of saline $(1.35 \pm 0.11 \mathrm{ng} / \mathrm{ml})$. Infusion of UFP-101 had no significant effect on frequency (Fig 7C; $3.59 \pm 1.84$ pulses/4 hr) compared to saline-infusion $(1.67 \pm 0.37$ pulses/4 hr). Given the paucity of LH secretion of ovary-intact anestrous ewes during a 4hr sampling period, we were unable to statistically compare mean LH pulse amplitude between UFP-101 infused ewes (Fig 7B; $1.17 \pm 0.34 \mathrm{ng} / \mathrm{ml})$ and saline infused ewes $(0.69 \pm 0.04 \mathrm{ng} / \mathrm{ml})$.

\section{DISCUSSION}

These data provide evidence for an important role of OFQ in the negative feedback control of GnRH/LH secretion in the ewe. Our observation that most OFQ neurons in the ARC contain ER $\alpha$ and PR fits with the idea that OFQ could mediate hypothalamic actions of ovarian steroids on LH secretion. Furthermore, administration of an OFQ receptor antagonist into the lateral ventricle of $\mathrm{OVX}+\mathrm{P}+\mathrm{E}_{2}$ ewes increased LH pulse frequency. In contrast, no effect was observed in $\mathrm{OVX}+\mathrm{E}_{2}$ or ovary-intact anestrous ewes, which solidifies a role for endogenous OFQ in mediating progesterone negative feedback.

The distribution of OFQ-containing neurons throughout the POA and hypothalamus herein is similar to that seen previously in sheep (19), as well as in rats (16) and humans (18). Also, the distribution of ER $\alpha$ - and PR-containing cells also matches previous reports in the ewe $(7,31)$. Our finding that OFQ-containing neurons in the POA do not express ER $\alpha$ or PR is consistent with an observation that, within the POA, OFQ is coexpressed predominantly in GnRH neurons (19) and that GnRH neurons do not express either steroid receptor $(5,6)$. Therefore, steroid negative feedback most 
likely is not exerted directly through OFQ neurons located in the POA. In contrast, a relatively high percentage of OFQ neurons in various hypothalamic regions contain $\mathrm{ER} \alpha$ and $\mathrm{PR}$, with the highest colocalization in the ARC. This high percentage of ARC OFQ neurons containing ER $\alpha$ and PR (ER $\alpha, 80-$ $100 \%$; PR, $60-80 \%$ ) is in contrast to many other steroid receptor containing neural populations in the ARC such as those containing AgRP (ER $\alpha, 3-10 \%$; PR, 15\%), dopamine (ER $\alpha, 15 \%$; PR, 20\%) and POMC (ER $\alpha, 15-20 \%$; PR, 28\%) neurons (6, 32-34), but quite similar to the kisspeptin population of the ARC (ER $\alpha$ and PR, 95\%;(35)).

Given the variety of steroid receptor containing neurons in the ARC, we investigated if ARC OFQ neurons coexpressed other neuropeptides that are also colocalized with ER $\alpha$ and PR. Within the ARC, we did not observe colocalization of OFQ with AgRP, dopamine (using TH as a marker) or kisspeptin. However, we did observe that approximately 50\% of ARC POMC neurons coexpress OFQ. Based on this, the percentage of OFQ neurons containing steroid receptors is slightly higher than might be expected based on reports in the rat POMC/ER $\alpha / P R$ colocation $(15 \% ;(36))$ and sheep $(15-28 \% ;(6,34))$. This difference most likely reflects the different antibodies utilized in each experiment because we used an antibody against the preprohormone, while others have used markers for cleaved products of POMC (i.e., $\beta$-endophin and $\alpha$-MSH). Furthermore, since close appositions from POMC neurons have been observed on GnRH neurons throughout the ovine hypothalamus (12) and the high degree of colocalization of POMC with OFQ, it is possible that this opioid could have direct input to GnRH neurons.

The use of opioid antagonists has helped define a role for EOP in mediating steroid negative feedback on GnRH/LH secretion in several species. Administration of naloxone, a nonspecific EOP receptor antagonist, increased LH secretion in the follicular and luteal phase of both women (37) and sheep (38). Furthermore, although ineffective in OVX ewes, WIN-444431, a long-acting nonspecific opioid antagonist, increases LH secretion in OVX ewes treated with $\mathrm{E}_{2}$ and progesterone (8). Since these initial studies it has been shown that dynophin is a key factor for progesterone negative feedback in the ewe (12). However, we recently reported that local administration of progesterone to the caudal ARC, targeting dynorphin neurons, was not sufficient to suppress LH secretion in OVX ewes, while local 
administration of a PR antagonist, RU486, to the ARC increased LH secretion in ewes that received peripheral progesterone treatment (13). Therefore, we suggested that dynorphin alone is not sufficient to mediate all the effects of progesterone on $\mathrm{GnRH} / \mathrm{LH}$ secretion and that other neurons, presumably within the medial basal hypothalamus because of the local action of RU486, are also likely to contribute to progesterone negative feedback.

Evidence of a hypothalamic role for OFQ in control of GnRH secretion continues to grow. The first evidence of this was reported in the guinea pig where OFQ hyperpolarized GnRH neurons within the medial basal hypothalamus (39). Since then it has been shown in vivo that central administration of OFQ inhibits LH secretion $(20,40)$, GnRH concentrations in push-pull perfusates $(20,40)$ and GnRH pulse frequency in hypophyseal portal blood (41). OFQ-positive neurons containing ER $\alpha$ and PR could mediate the effects of steroid negative feedback on GnRH/LH secretion. We observed an increased LH pulse frequency with infusion of an OFQ receptor antagonist into the lateral ventricle of OVX ewes with luteal phase concentrations of $\mathrm{E}_{2}$ and progesterone. Furthermore, an alternative source of steroid production has emerged with the hypothesis that estradiol stimulates central production (neurosteroidogensis) of progesterone $(42,43)$, which could account for actions of estradiol at the level of the brain. However, we did not observe a significant effect of the OFQ receptor antagonist on LH secretion in OVX $+\mathrm{E}_{2}$ ewes or intact, anestrous ewes. Therefore, we conclude it is unlikely that OFQ is involved in estradiol-negative feedback, either directly through ER $\alpha$ or indirectly through neurosteroidogenesis, but can mediate steroid negative feedback of peripheral progesterone on GnRH/LH secretion in the ewe.

ORL-1 mRNA is detectable in the medial preoptic area, SON, PVN, VMN and ARC (18), but limited data exists for steroid effects on OFQ or its receptor. One study in rats reports an increase in ORL-1 mRNA following treatment of rats with either $\mathrm{E}_{2}$ or $\mathrm{E}_{2}+\mathrm{P}$, while changes in peptide were only observed in $\mathrm{E}_{2}+\mathrm{P}$ treated rats (44). Therefore, it might be possible that estradiol increases ORL-1 expression while progesterone increases OFQ expression. This would account for the increase in LH pulse frequency in ewes with luteal phase concentrations of progesterone and estradiol given that the 
combination of these steroids results in increased endogenous OFQ release that is blocked by our infusion of UFP-101. However, experiments with steroid effects on OFQ and ORL-1 expression in species other than rat remain to be done. Furthermore, given the colocalization of OFQ and GnRH in the POA (19) and POMC in the ARC (herein) and since OFQ has been shown to inhibit both GnRH and POMC neurons in the medial basal hypothalamus of guniea pigs (39), we propose an autocrine action of OFQ. This would help explain the sychronized GnRH pulsatile secretion in imortalized GnRH cells (45), GnRH neurons from nasal explants (46), and GnRH neurons in vivo; however, it remains to be determined which neurons (i.e., GnRH and/or POMC neurons) contain ORL-1. In summary, we show that OFQ neurons colocalize with both ER $\alpha$ and PR in multiple areas of the hypothalamus as well as with POMC neurons in the ARC. Furthermore, we show that antagonizing the receptor for OFQ increases LH pulse frequency in progesterone-treated, but not estradiol-treated, ewes. Thus, our data support a role for OFQ in progesterone negative feedback on LH secretion in the ewe.

\section{ACKNOWLEDGEMENTS}

We thank Heather Bungard and Jennifer Lydon (West Virginia University Food Animal Research Facility) for care of animals. We also thank Dr. Al Parlow and the National Hormone and Peptide Program for reagents used to measure LH and Dr. Alain Caray for the gift of kisspeptin antibody. We also want to thank Dr. Holaskova for help with collection of preliminary data for the antagonist experiments. 


\section{REFERENCE LIST}

1. Evans NP, Dahl GE, Glover BH, Karsch FJ 1994 Central regulation of pulsatile gonadotropinreleasing hormone $(\mathrm{GnRH})$ secretion by estradiol during the period leading up to the preovulatory GnRH surge in the ewe. Endocrinology 134:1806-1811

2. Goodman RL, Parfitt DB, Evans NP, Dahl GE, Karsch FJ 1995 Endogenous opioid peptides control the amplitude and shape of gonadotropin-releasing hormone pulses in the ewe. Endocrinology 136:2412-2420

3. Clarke IJ, Thomas GB, Yao B, Cummins JT 1987 GnRH secretion throughout the ovine estrous cycle. Neuroendocrinology 46:82-88

4. Karsch FJ, Cummins JT, Thomas GB, Clarke IJ 1987 Steroid feedback inhibition of pulsatile secretion of gonadotropin-releasing hormone in the ewe. Biol Reprod 36:1207-1218

5. Herbison AE, Robinson JE, Skinner DC 1993 Distribution of estrogen receptorimmunoreactive cells in the preoptic area of the ewe: co-localization with glutamic acid decarboxylase but not luteinizing hormone-releasing hormone. Neuroendocrinology 57:751-759

6. Lehman MN, Karsch FJ 1993 Do gonadotropin-releasing hormone, tyrosine hydroxylase-, and beta-endorphin-immunoreactive neurons contain estrogen receptors? A double-label immunocytochemical study in the Suffolk ewe. Endocrinology 133:887-895

7. Skinner DC, Caraty A, Allingham R 2001 Unmasking the progesterone receptor in the preoptic area and hypothalamus of the ewe: no colocalization with gonadotropin-releasing neurons. Endocrinology 142:573-579

8. Whisnant CS, Goodman RL 1988 Effects of an opioid antagonist on pulsatile luteinizing hormone secretion in the ewe vary with changes in steroid negative feedback. Biol Reprod 39:1032-1038

9. Horton RJ, Cummins JT, Clarke IJ 1987 Naloxone evokes large-amplitude GnRH pulses in luteal-phase ewes. J Reprod Fertil 81:277-286 
10. Foradori CD, Coolen LM, Fitzgerald ME, Skinner DC, Goodman RL, Lehman MN 2002 Colocalization of progesterone receptors in parvicellular dynorphin neurons of the ovine preoptic area and hypothalamus. Endocrinology 143:4366-4374

11. Foradori CD, Goodman RL, Adams VL, Valent M, Lehman MN 2005 Progesterone increases dynorphin a concentrations in cerebrospinal fluid and preprodynorphin messenger ribonucleic Acid levels in a subset of dynorphin neurons in the sheep. Endocrinology 146:1835-1842

12. Goodman RL, Coolen LM, Anderson GM, Hardy SL, Valent M, Connors JM, Fitzgerald ME, Lehman MN 2004 Evidence that dynorphin plays a major role in mediating progesterone negative feedback on gonadotropin-releasing hormone neurons in sheep. Endocrinology 145:2959-2967

13. Goodman RL, Holaskova I, Nestor CC, Connors JM, Billings HJ, Valent M, Lehman MN, Hileman SM 2011 Evidence that the arcuate nucleus is an important site of progesterone negative feedback in the ewe. Endocrinology 152:3451-3460

14. Reinscheid RK, Nothacker HP, Bourson A, Ardati A, Henningsen RA, Bunzow JR, Grandy DK, Langen H, Monsma FJ, Jr., Civelli O 1995 Orphanin FQ: a neuropeptide that activates an opioidlike G protein-coupled receptor. Science 270:792-794

15. Meunier JC, Mollereau C, Toll L, Suaudeau C, Moisand C, Alvinerie P, Butour JL, Guillemot JC, Ferrara P, Monsarrat B, et al. 1995 Isolation and structure of the endogenous agonist of opioid receptor-like ORL1 receptor. Nature 377:532-535

16. Neal CR, Jr., Mansour A, Reinscheid R, Nothacker HP, Civelli O, Watson SJ, Jr. 1999 Localization of orphanin FQ (nociceptin) peptide and messenger RNA in the central nervous system of the rat. J Comp Neurol 406:503-547

17. Neal CR, Jr., Mansour A, Reinscheid R, Nothacker HP, Civelli O, Akil H, Watson SJ, Jr. 1999 Opioid receptor-like (ORL1) receptor distribution in the rat central nervous system: comparison of ORL1 receptor mRNA expression with (125)I-[(14)Tyr]-orphanin FQ binding. J Comp Neurol 412:563-605 
18. Neal CR, Jr., Akil H, Watson SJ, Jr. 2001 Expression of orphanin FQ and the opioid receptorlike (ORL1) receptor in the developing human and rat brain. J Chem Neuroanat 22:219-249

19. Foradori CD, Amstalden M, Coolen LM, Singh SR, McManus CJ, Handa RJ, Goodman RL, Lehman MN 2007 Orphanin FQ: evidence for a role in the control of the reproductive neuroendocrine system. Endocrinology 148:4993-5001

20. An XF, Chen HP, Ma SL, Feng Y, Hao JW, Chen BY 2005 Involvement of nociceptin/orphanin FQ in release of hypothalamic GnRH mediated by ORL1 receptor in ovariectomized rats. Acta Pharmacol Sin 26:1039-1044

21. An XF, Yu JY, Feng Y, Chen BY, Zhang SL 2007 Role of hypothalamus nociceptin/orphanin FQ in pre-ovulatory luteinizing hormone surge of estrogen and progesterone-primed, ovariectomized rats. Acta Pharmacol Sin 28:1189-1197

22. Sheppard KM, Padmanabhan V, Coolen LM, Lehman MN 2011 Prenatal programming by testosterone of hypothalamic metabolic control neurones in the ewe. J Neuroendocrinol 23:401411

23. Goodman RL, Lehman MN, Smith JT, Coolen LM, de Oliveira CV, Jafarzadehshirazi MR, Pereira A, Iqbal J, Caraty A, Ciofi P, Clarke IJ 2007 Kisspeptin neurons in the arcuate nucleus of the ewe express both dynorphin A and neurokinin B. Endocrinology 148:5752-5760

24. Singh SR, Hileman SM, Connors JM, McManus CJ, Coolen LM, Lehman MN, Goodman RL 2009 Estradiol negative feedback regulation by glutamatergic afferents to A15 dopaminergic neurons: variation with season. Endocrinology 150:4663-4671

25. Hileman SM, Lubbers LS, Jansen HT, Lehman MN 1999 Changes in hypothalamic estrogen receptor-containing cell numbers in response to feed restriction in the female lamb. Neuroendocrinology 69:430-437

26. Anderson GM, Connors JM, Hardy SL, Valent M, Goodman RL 2001 Oestradiol microimplants in the ventromedial preoptic area inhibit secretion of luteinizing hormone via dopamine neurones in anoestrous ewes. J Neuroendocrinol 13:1051-1058 
27. Foradori CD, Amstalden M, Goodman RL, Lehman MN 2006 Colocalisation of dynorphin a and neurokinin B immunoreactivity in the arcuate nucleus and median eminence of the sheep. $\mathbf{J}$ Neuroendocrinol 18:534-541

28. Scott CJ, Tilbrook AJ, Simmons DM, Rawson JA, Chu S, Fuller PJ, Ing NH, Clarke IJ 2000 The distribution of cells containing estrogen receptor-alpha (ERalpha) and ERbeta messenger ribonucleic acid in the preoptic area and hypothalamus of the sheep: comparison of males and females. Endocrinology 141:2951-2962

29. Skinner DC, Evans NP, Delaleu B, Goodman RL, Bouchard P, Caraty A 1998 The negative feedback actions of progesterone on gonadotropin-releasing hormone secretion are transduced by the classical progesterone receptor. Proc Natl Acad Sci U S A 95:10978-10983

30. Karsch FJ, Weick RF, Hotchkiss J, Dierschke DJ, Knobil E 1973 An analysis of the negative feedback control of gonadotropin secretion utilizing chronic implantation of ovarian steroids in ovariectomized rhesus monkeys. Endocrinology 93:478-486

31. Lehman MN, Ebling FJ, Moenter SM, Karsch FJ 1993 Distribution of estrogen receptorimmunoreactive cells in the sheep brain. Endocrinology 133:876-886

32. Skinner DC, Herbison AE 1997 Effects of photoperiod on estrogen receptor, tyrosine hydroxylase, neuropeptide $\mathrm{Y}$, and beta-endorphin immunoreactivity in the ewe hypothalamus. Endocrinology 138:2585-2595

33. Dufourny L, Caraty A, Clarke IJ, Robinson JE, Skinner DC 2005 Progesterone-receptive dopaminergic and neuropeptide Y neurons project from the arcuate nucleus to gonadotropinreleasing hormone-rich regions of the ovine preoptic area. Neuroendocrinology 82:21-31

34. Dufourny L, Caraty A, Clarke IJ, Robinson JE, Skinner DC 2005 Progesterone-receptive beta-endorphin and dynorphin B neurons in the arcuate nucleus project to regions of high gonadotropin-releasing hormone neuron density in the ovine preoptic area. Neuroendocrinology $81: 139-149$ 
35. Lehman MN, Coolen LM, Goodman RL 2010 Minireview: kisspeptin/neurokinin B/dynorphin (KNDy) cells of the arcuate nucleus: a central node in the control of gonadotropin-releasing hormone secretion. Endocrinology 151:3479-3489

36. Maolood N, Meister B 2010 Nociceptin/orphanin FQ peptide in hypothalamic neurones associated with the control of feeding behaviour. J Neuroendocrinol 22:75-82

37. Quigley ME, Yen SS 1980 The role of endogenous opiates in LH secretion during the menstrual cycle. J Clin Endocrinol Metab 51:179-181

38. Brooks AN, Lamming GE, Lees PD, Haynes NB 1986 Opioid modulation of LH secretion in the ewe. J Reprod Fertil 76:693-708

39. Wagner EJ, Ronnekleiv OK, Grandy DK, Kelly MJ 1998 The peptide orphanin FQ inhibits beta-endorphin neurons and neurosecretory cells in the hypothalamic arcuate nucleus by activating an inwardly-rectifying K+ conductance. Neuroendocrinology 67:73-82

40. An XF, He M, Feng Y, Feng H, Yu JY 2009 Central administration of Orphanin FQ inhibits GnRH secretion by ORL1 receptor in the median eminence of freely moving ovariectomized rats. Neurosci Bull 25:1-6

41. Nestor CC 2009 Orphanin FQ acts primarily at the hypothalamus to inhibit pulsatile LH secretion in sheep Society for Neuroscience, Chicago, IL, 2009

42. Micevych P, Sinchak K 2008 Estradiol regulation of progesterone synthesis in the brain. Mol Cell Endocrinol 290:44-50

43. Micevych P, Sinchak K 2008 Synthesis and function of hypothalamic neuroprogesterone in reproduction. Endocrinology 149:2739-2742

44. Sinchak K, Romeo HE, Micevych PE 2006 Site-specific estrogen and progestin regulation of orphanin FQ/nociceptin and nociceptin opioid receptor mRNA expression in the female rat limbic hypothalamic system. J Comp Neurol 496:252-268 
45. Wetsel WC, Valenca MM, Merchenthaler I, Liposits Z, Lopez FJ, Weiner RI, Mellon PL, Negro-Vilar A 1992 Intrinsic pulsatile secretory activity of immortalized luteinizing hormonereleasing hormone-secreting neurons. Proc Natl Acad Sci U S A 89:4149-4153

46. Terasawa E, Keen KL, Mogi K, Claude P 1999 Pulsatile release of luteinizing hormonereleasing hormone (LHRH) in cultured LHRH neurons derived from the embryonic olfactory placode of the rhesus monkey. Endocrinology 140:1432-1441 


\section{FIGURE LEGENDS}

Figure 1: Panel A and B: Photomicrographs of OFQ immunoreactive cells (brown cytoplasm) and ER $\alpha$ (blue-black nuclei) in the ovine ARC. Inset of Panel A is shown at higher magnification in Panel B. Panel C: Mean $( \pm$ SEM) number of OFQ positive cells in the POA and various hypothalamic areas of mid-luteal phase ewes. Panel D: Mean $( \pm$ SEM) number of ER $\alpha$ positive nuclei in the POA and various hypothalamic areas of mid-luteal phase ewes. Panel E: Percentage of OFQ neurons that colocalize with ER $\alpha$ in the POA and various hypothalamic areas. Red arrows indicate OFQ neurons colocalized with ER $\alpha .3 V=$ third ventricle. Produced in collaboration with our colleagues at The University of Michigan.

Figure 2: Panel A and B: Photomicrographs of OFQ immunoreactive cells (brown cytoplasm) and PR (blue-black nuclei) in the ovine ARC. Inset of Panel A is shown at higher magnification in Panel B. Panel C: Mean $( \pm$ SEM) number of OFQ positive cells in the POA and various hypothalamic areas of mid-luteal phase ewes. Panel D: Mean $( \pm$ SEM) number of PR positive nuclei in the POA and various hypothalamic areas of mid-luteal phase ewes. Panel E: Percentage of OFQ neurons that colocalize with PR in the POA and various hypothalamic areas. Red arrows indicate OFQ neurons colocalized with PR. $3 \mathrm{~V}=$ third ventricle. Produced in collaboration with our colleagues at The University of Michigan Figure 3: Panel A-F: Confocal images ( $1 \mu \mathrm{m}$ optical section) through the ovine ARC processed for dual-immunoflourescence detection of OFQ (red) and either AgRP, kisspeptin, TH, or POMC (green). Single-labeled neurons of OFQ (Panel A) and POMC neurons (Panel B) are identified using arrowheads and merged image for dual-labeled OFQ/POMC neurons (Panel C) with colocalized neurons indicated with arrows. Merged images in bottom row show OFQ and kisspeptin (Panel D), AgRP (Panel E) or TH (Panel F). Produced in collaboration with our colleagues at The University of Michigan

Figure 4: Panel A-C: LH profiles from Experiment 2 of ewe \#258 that was OVX and treated sc with progesterone and estradiol. LH profiles during infusion of saline (Panel A), UFP-101 (Panel B) and JTC801 (Panel C) are shown with pulses identified using a closed circle. 
Figure 5: Group means ( \pm SEM) for mean LH (Panel A), LH pulse amplitude (Panel B) and LH pulse frequency (Panel C) for saline (open bars), UFP-101 (black bars) and JTC-801 (grey bars) infused OVX+P+E ewes $(n=8)$. Significant difference $(\mathrm{p}<0.05)$ from saline group is indicated by *

Figure 6: Group means $( \pm$ SEM) for mean LH (Panel A), LH pulse amplitude (Panel B) and LH pulse frequency (Panel C) for saline (open bars) and UFP-101 (black bars) infused OVX+E ewes (n=7).

Figure 7: Group means $( \pm$ SEM) for mean LH (Panel A), LH pulse amplitude (Panel B) and LH pulse frequency (Panel C) for saline (open bars) and UFP-101 (black bars) infused ovary-intact anestrous ewes $(\mathrm{n}=6)$. 


\section{FIGURES}

Figure 1

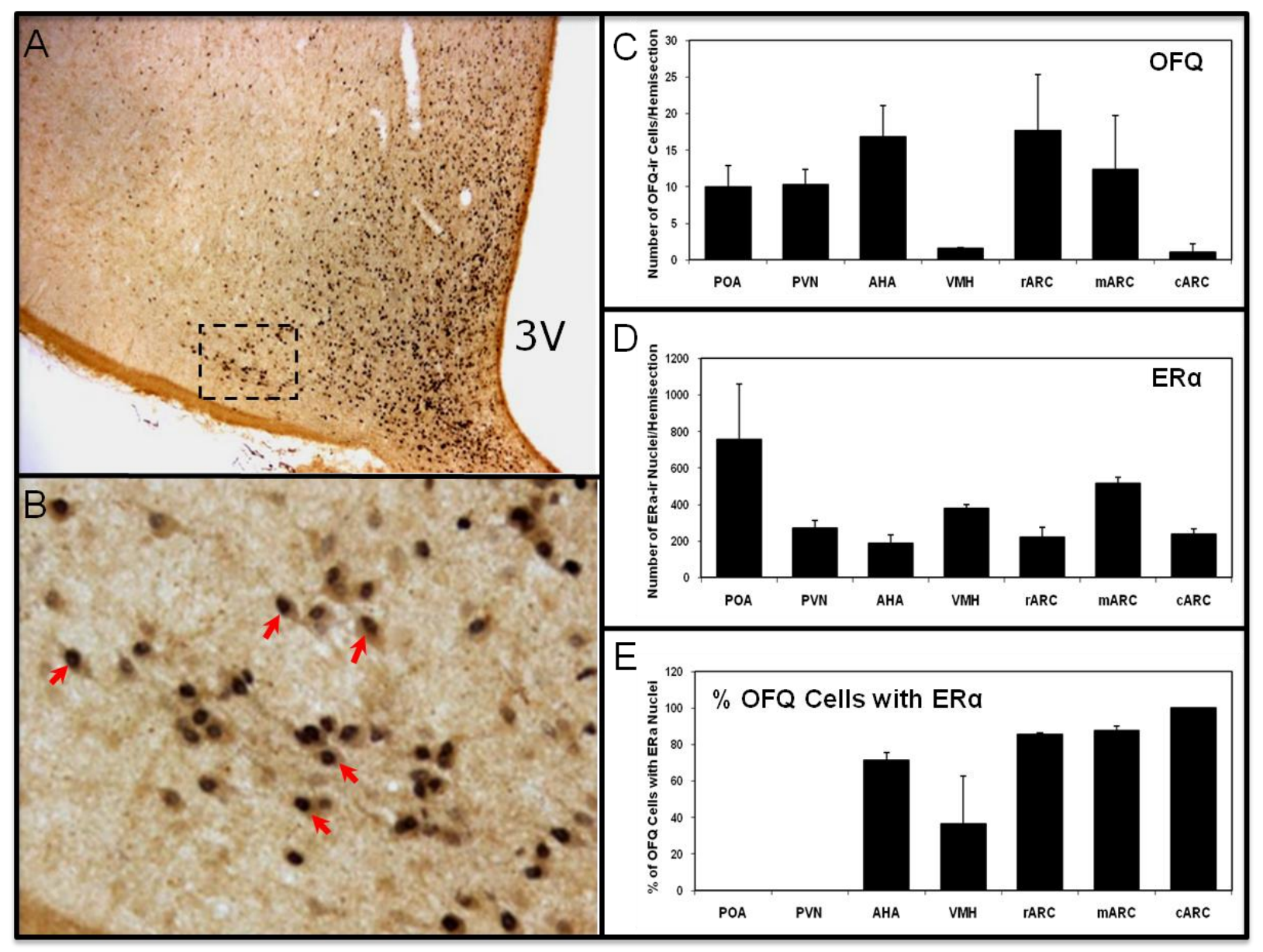


Figure 2

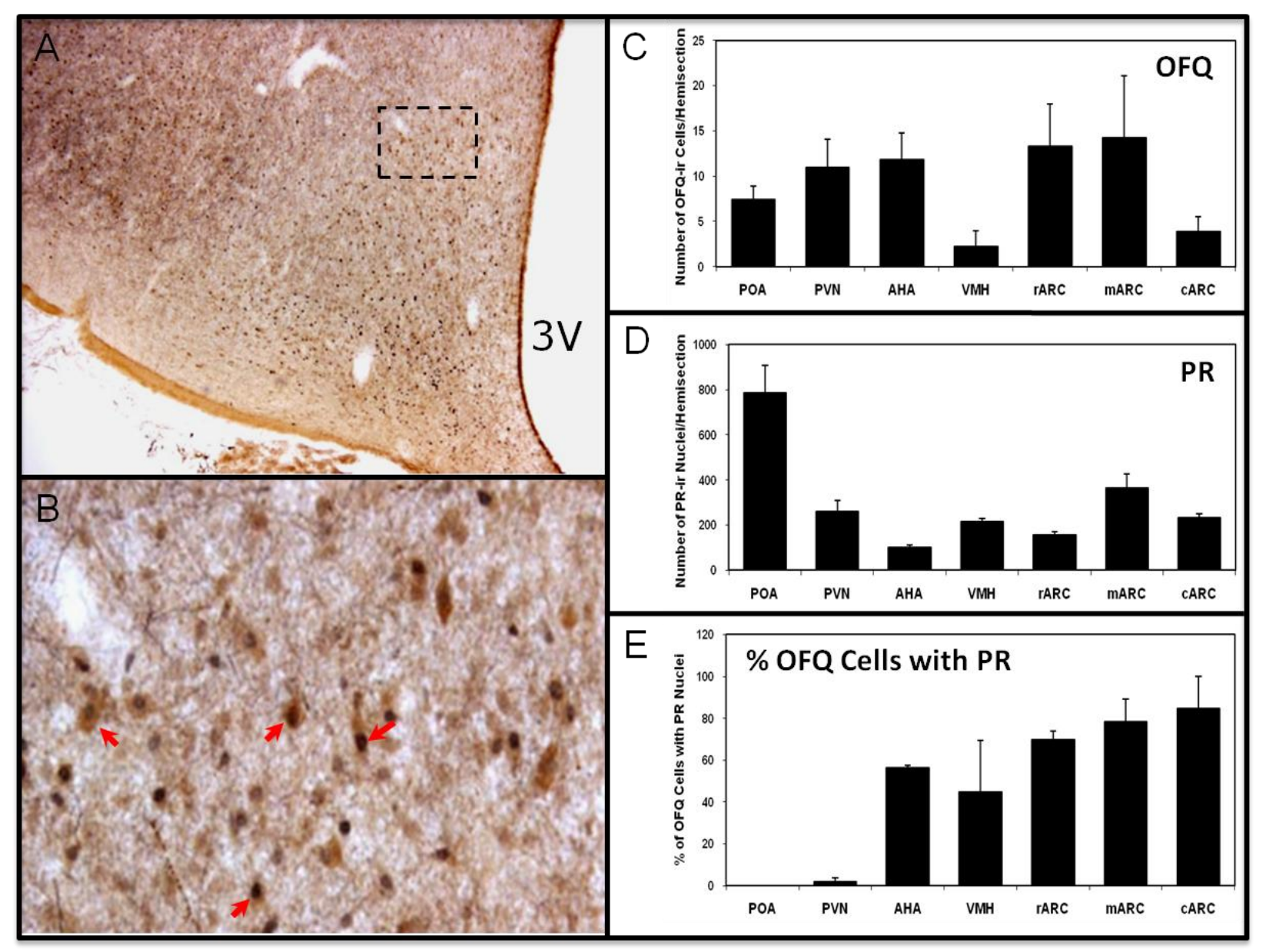


Figure 3

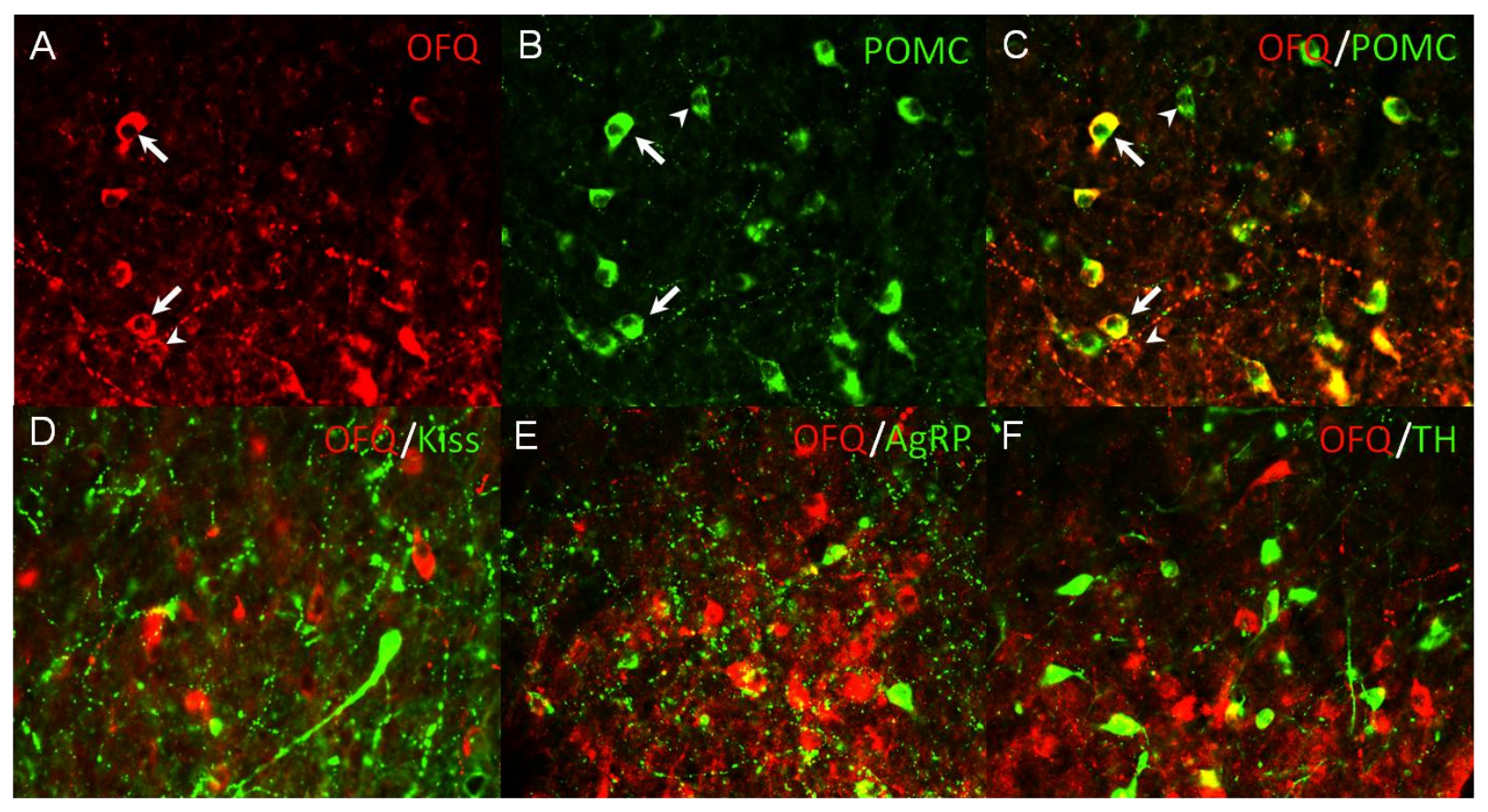


Figure 4
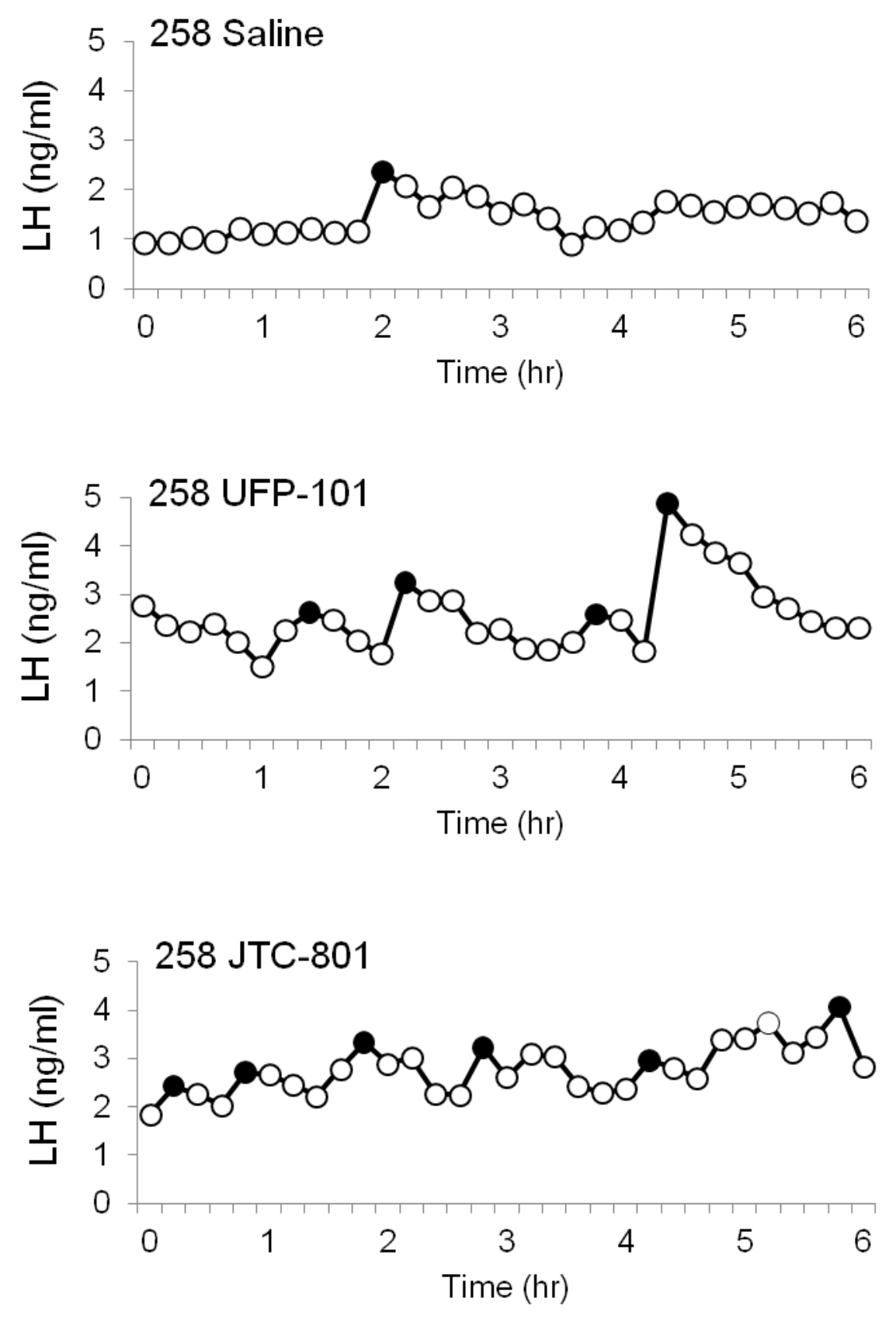
Figure 5

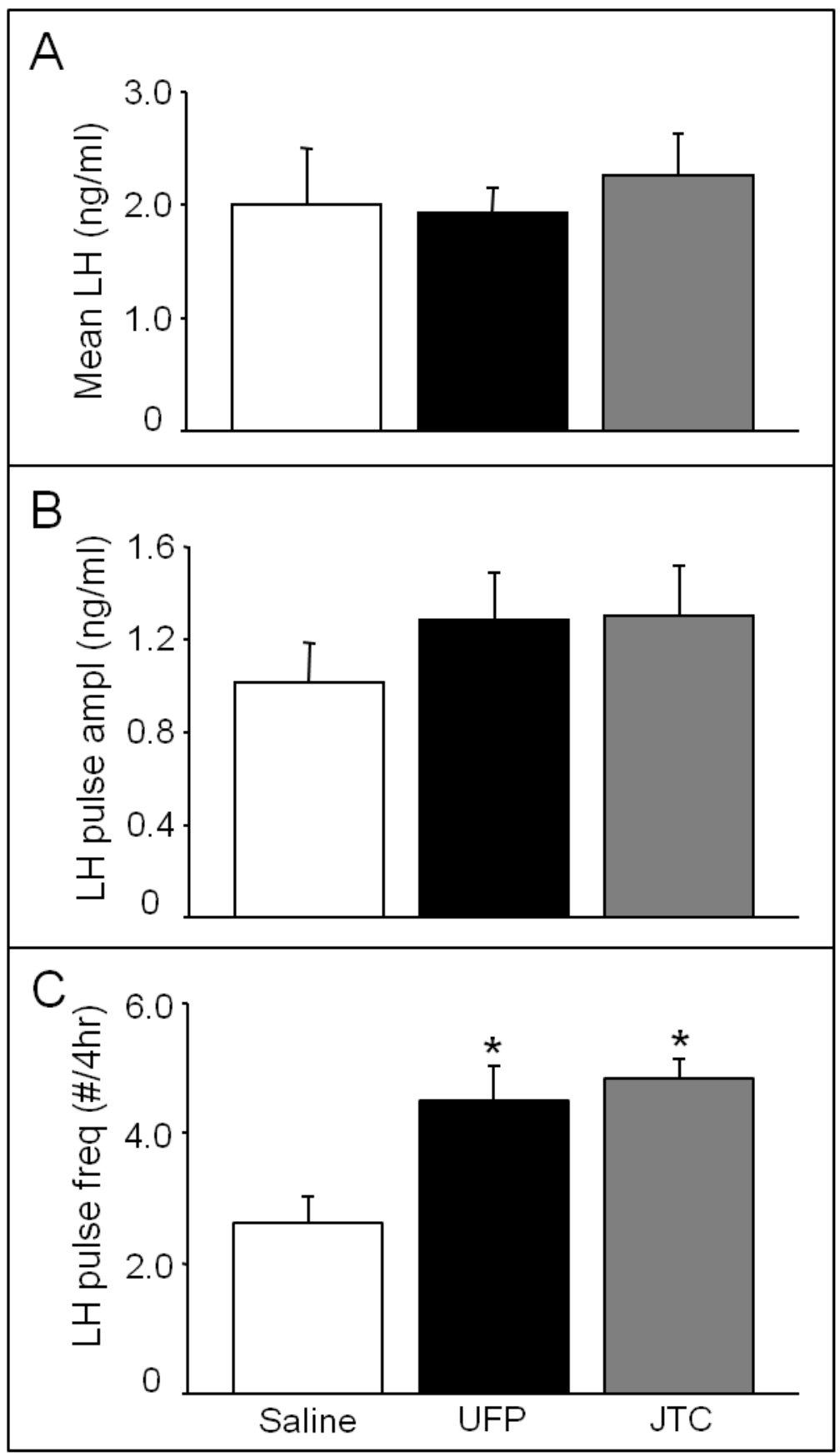


Figure 6

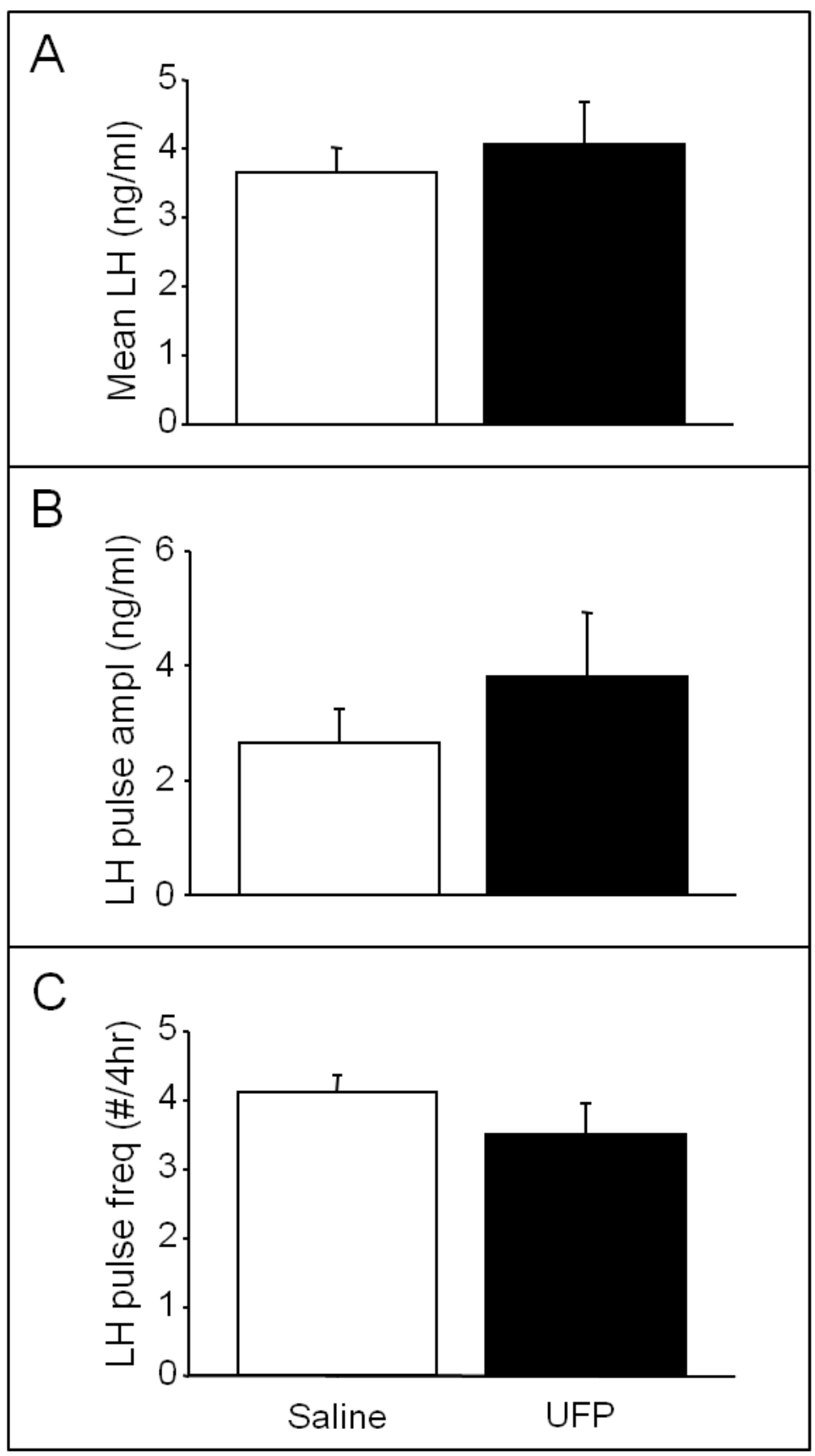


Figure 7

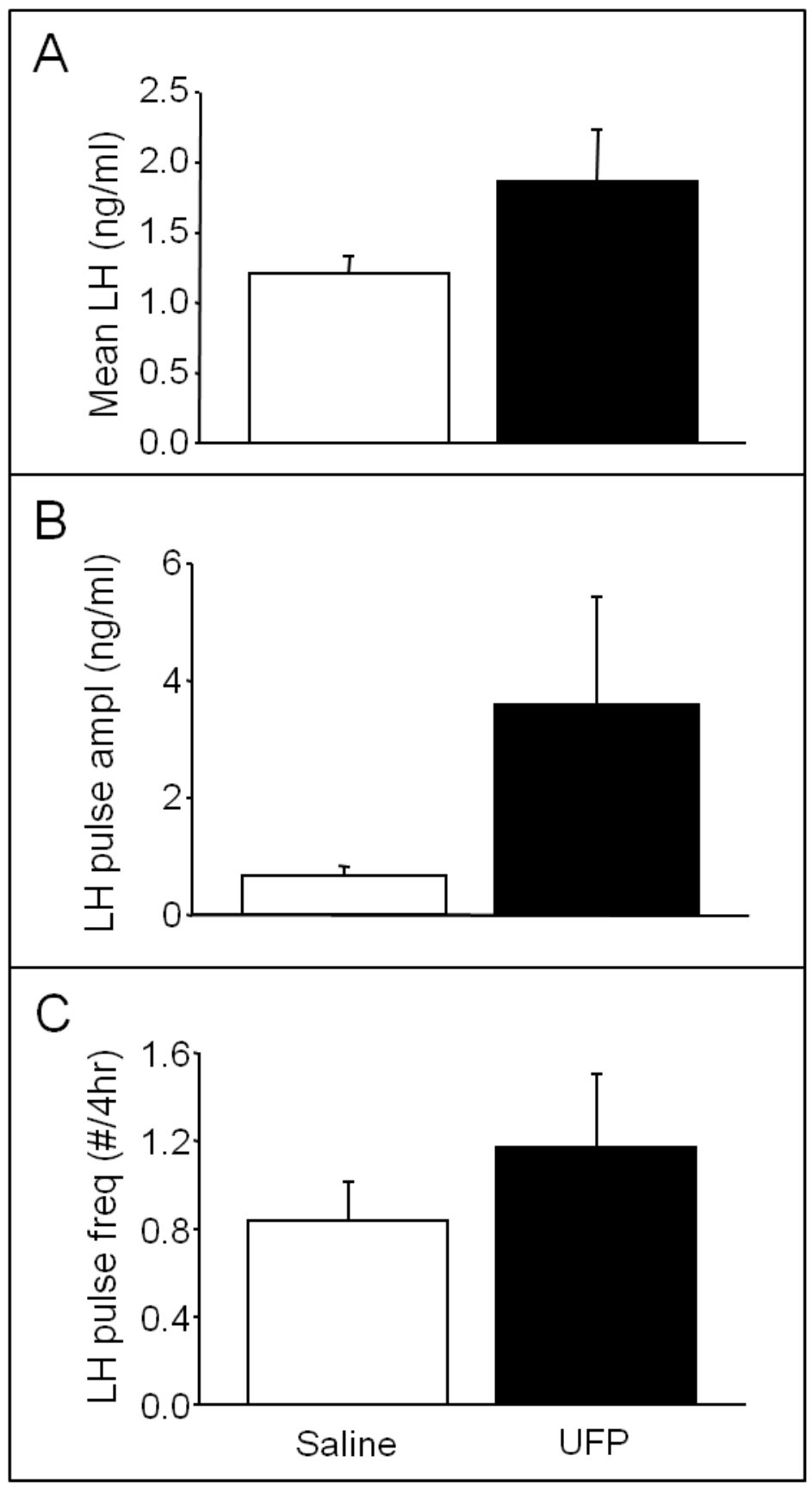


CHAPTER 5

GENERAL DISCUSSION 
The results presented in the preceding three chapters provide strong evidence of a role for kisspeptin, NKB and OFQ in the control of GnRH/LH secretion in the ewe. Therein we showed a greater number of kisspeptin, but not NKB, positive cell bodies in the ARC in postpubertal compared to prepubertal ewes. In addition, it appears that the site of action for OFQ on LH secretion is at the hypothalamus and not at the anterior pituitary. Lastly, we demonstrated that OFQ, at least in part, mediates progesterone negative feedback in the ewe.

\section{KISSPEPTIN AND NKB IN PUBERTY}

As previously mentioned, the pubertal increase in $\mathrm{GnRH} / \mathrm{LH}$ secretion is due to lessening of estradiol negative feedback allowing GnRH/LH pulse frequency to increase. In parallel with this increase in LH pulse frequency, we showed that the number of ARC kisspeptin positive neurons is higher in postpubertal ewes compared to prepubertal ewes. In mice, ablation of ARC kisspeptin neurons at $20 \mathrm{~d}$ of age (prior to the appearance of kisspeptin cells in the AVPV) completely abolished ovulatory cycles (1), which supports the idea that ARC kisspeptin is essential for puberty. Moreover, my observation that POA kisspeptin cells were lightly and inconsistently stained in the postpubertal ewe, leads me to conclude that this population of kisspeptin cells is unlikely to contribute to puberty in the female sheep.

Furthermore, with the inclusion of age-matched male sheep in this study, we demonstrate that this change in cell number is due to a pubertal event and not to age-related changes independent of reproduction. Also, we demonstrated that kisspeptin-positive close contacts on GnRH neurons in the mPOA are greater in postpubertal ewes compared to prepubertal ewes. Changes in kisspeptin contacts in the mPOA closely mirrored the changes we observed in cell numbers in the ARC, which leads us to postulate that kisspeptin neurons in the ARC project to GnRH neurons in the POA. Immunocytochemistry for kisspeptin, dynorphin and GnRH confirm this idea by showing that 50-70\% of GnRH neurons in the POA receive arcuate derived kisspeptin input (2). Together, our current working model for puberty (Figure 1) is that estradiol inhibits kisspeptin expression before puberty, but following growth and maturation, estradiol inhibition of kisspeptin lessens, allowing for an increase in GnRH/LH secretion. Therefore, kisspeptin is a gatekeeper to puberty onset in the ewe. 
In contrast to kisspeptin, the number of NKB positive neurons did not differ between prepubertal and postpubertal ewes, but did increase following steroid removal in both groups. Upon further examination of the photomicrographs, we observed greater NKB fiber density in the ARC of postpubertal ewes compared to prepubertal ewes. This increase in fiber density most likely reflects increased activity of the NKB system in the postpubertal ewe. Furthermore, we are the first to demonstrate in prepubertal females that senktide can stimulate LH secretion. Given the absence of this effect in the presence of acyline, the stimulation is not at the pituitary, but occurs centrally to stimulate GnRH secretion. Since when compared to postpubertal ewes, prepubertal ewes have a lower NKB fiber density and their LH response to senktide is intact, we suggest that NKB expression is merely inhibited by estradiol in the prepubertal ewe (Figure 1).

However, a few unresolved questions still remain. One, what is the relationship between kisspeptin and NKB during puberty? It is possible that NKB cell numbers increased prior to the prepubertal time point we examined. Given recent data with kisspeptin receptor knockout mice that demonstrates NKB actions are upstream of kisspeptin (3), an increase in NKB expression may occur prior to and drive the increase in kisspeptin expression at the time of puberty. This still allows for kisspeptin to be the gatekeeper in ovine puberty, but also includes an active role for NKB. Furthermore, although we focused solely on stimulatory afferent neurons, what might the inhibitory afferent neurons be that could inhibit GnRH/LH secretion in the prepubertal ewe? One possibility that remains to be investigated is an inhibitory role for dynorphin prepubertally that lessens at the time of puberty. Another candidate is gamma-aminobutyric acid (GABA) given that a $\mathrm{GABA}_{\mathrm{A}}$ receptor antagonist increases $\mathrm{LH}$ secretion in prepubertal, but not in the adult, monkeys (4). Therefore, the increase in GnRH/LH secretion in the ewe may be due to an increase in kisspeptin cell numbers, an increase in NKB activity and a decrease in dynorphin and/or GABA inhibition. In addition, leptin is a key signal for puberty onset, it remains to be determined how leptin can act on the kisspeptin/NKB system to alter GnRH/LH secretion (5). 
Figure 1

\section{Prepubertal}
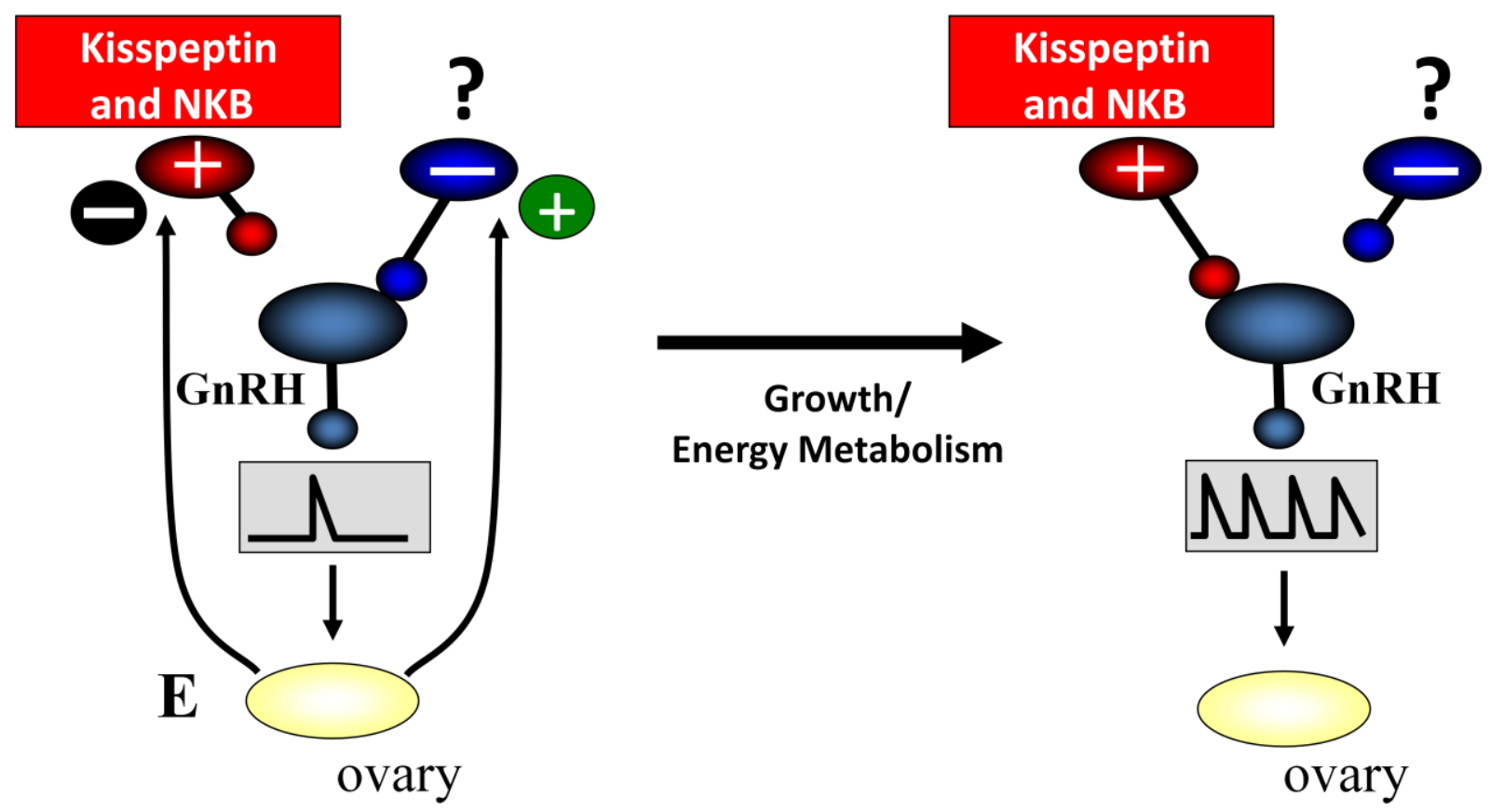

Figure 1: Current working model for neuroendocrine pubertal development in the ewe. Potent estradiol negative feedback in the prepubertal ewe reduces kisspeptin and NKB input to GnRH neurons. As the ewe grows and matures, estradiol negative feedback lessens allowing kisspeptin and NKB input to increase resulting in an increase in GnRH/LH secretion. 


\section{SITE OF ACTION FOR OFQ}

Previous reports demonstrate that central administration of OFQ inhibits LH secretion in the ewe (6) and in rodents $(7,8)$. We reported herein that various concentrations of OFQ alone applied directly to anterior pituitary cells have no effect on LH release. When challenged with increasing doses of GnRH, anterior pituitary cells respond with increasing concentrations of LH. However, incubation starting before with OFQ did not alter GnRH-induced LH release from these cultured anterior pituitary cells. Therefore, we conclude OFQ most likely does not act directly at the pituitary to inhibit LH secretion.

Since collection of hypophyseal portal blood in an unanesthetized animal can only be accomplished in sheep, our unique experimental model allows us to address the question of whether or not OFQ acts hypothalamically to inhibit GnRH secretion. Infusion of saline into the third ventricle had no effect on GnRH or LH secretion in OVX ewes. However, when OVX ewes received an infusion of OFQ agonist into the third ventricle, GnRH and LH secretion were suppressed. The suppression in LH secretion was due to a reduction in GnRH pulse frequency in the final two hours of infusion of the OFQ agonist. However, an unanticipated increase in GnRH baseline occurred during the final 2 hours of infusion and might be due to asynchronous GnRH release where low amplitude GnRH pulses are too low

to detect in 10 min sampling intervals. Therefore, we plan to address this in a subsequent experiment by decreasing portal blood sampling intervals to 2 min to examine GnRH pulse dynamics. Nonetheless, OFQ can clearly act at the hypothalamus to decrease GnRH pulse frequency into hypophyseal portal blood.

\section{ROLE FOR ENDOGENOUS OFQ}

It is now accepted that dynorphin is an important mediator of progesterone negative feedback in the ewe since administration of a $\kappa$-receptor antagonist increases LH pulse frequency in luteal phase ewes (9). However, given the central suppressive effect of an OFQ agonist on GnRH/LH secretion, a role for endogenous OFQ could exist to mediate steroid negative feedback on GnRH neurons as well. We first investigated whether or not OFQ neurons in the hypothalamus contain steroid receptors. We observed colocalization of both ER $\alpha$ and PR with OFQ neurons in multiple areas of the hypothalamus including the 
ARC. POA OFQ neurons did not colocalize with steroid receptors, which is consistent with the finding that most POA OFQ cells are also GnRH neurons and that GnRH neurons are devoid of steroid receptors. Also, we show that OFQ does not colocalize with kisspeptin neurons in the ARC, but does colocalize with POMC neurons, which has also been observed in the rat (10). Furthermore, we tested this idea of a physiological role using an OFQ receptor antagonist, UFP-101, in the presence of ovarian steroids in breeding season ewes. When infused into the lateral ventricle of $\mathrm{OVX}+\mathrm{P}+\mathrm{E}_{2}$ ewes, an $\mathrm{OFQ}$ receptor antagonist increased LH pulse frequency compared to saline infused animals. However, LH secretion in $\mathrm{OVX}+\mathrm{E}_{2}$ breeding season ewes was unaffected by infusion of UFP-101. Similarly, no effect of UFP-101 was observed in ovary-intact anestrous ewes, in which progesterone levels are undetectable and low levels of estradiol inhibit LH pulse frequency. From this we conclude that OFQ does not act during the non-breeding season to mediate steroid negative feedback of estradiol. However, since the antagonist increased LH secretion only in the presence of progesterone, we conclude that OFQ mediates, at least in part, progesterone negative feedback in the breeding season ewe. The current working model, including the anatomical and functional data presented herein, for progesterone negative feedback in the ewe is illustrated Figure 2.

Nonetheless, some unresolved issues still remain. First, although in rat and humans (11) a general distribution of ORL-1 exists, it is uncertain which neurons in the POA and hypothalamus contain this opioid receptor. Second, it would be beneficial to characterize the expression of OFQ and ORL-1 in the POA and hypothalamus across the estrous cycle to understand how changes in this opioid system might result in changes in GnRH/LH secretion. Third, although both dynorphin and OFQ can mediate progesterone negative feedback, whether they act in series or in parallel remains to be investigated. Furthermore, since OFQ colocalizes with GnRH and POMC, but also inhibits these neurons in the medial basal hypothalamus, it is possible that OFQ might serve an autocrine function. Thus, we have only just begun to scratch the surface of how OFQ can mediate progesterone negative feedback on GnRH/LH secretion. 
Figure 2

\section{MODEL FOR PROGESTERONE NEGATIVE FEEDBACK}

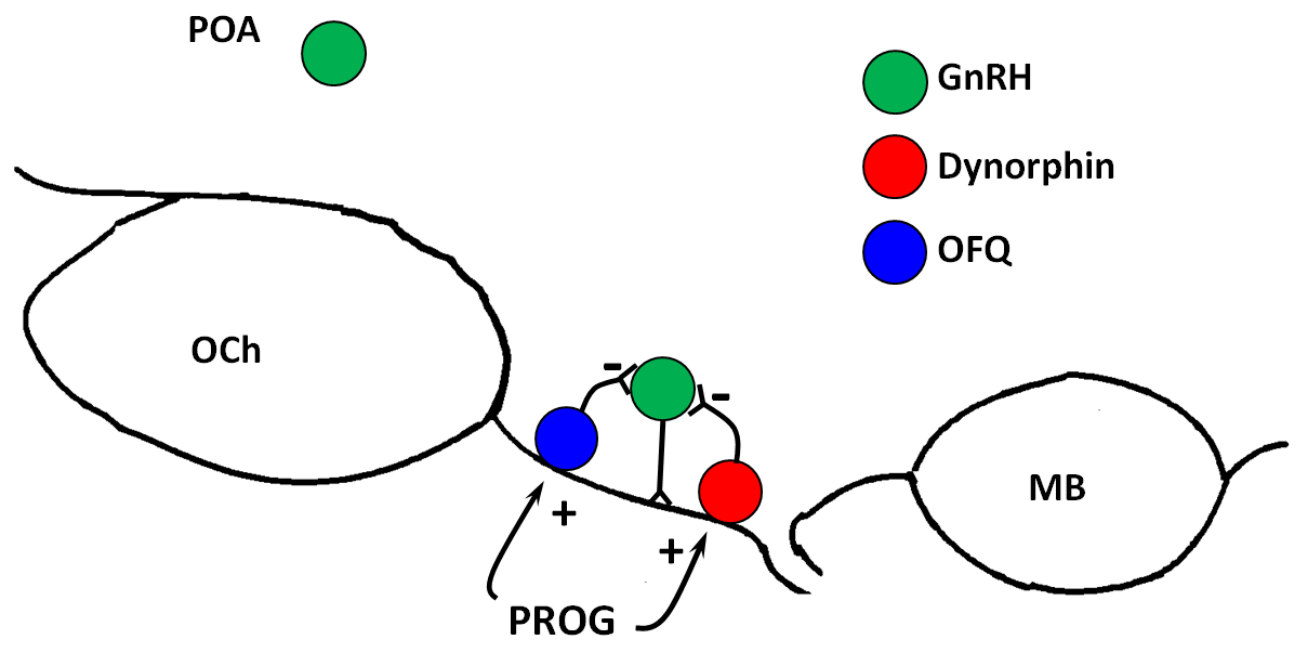

Figure 2: Current working model for OFQ and dynorphin mediating progesterone negative feedback.

Progesterone stimulates dynorphin and OFQ secretion within the MBH to inhibit GnRH secretion. 


\section{REFERNCE LIST}

1. Mayer C, Boehm U 2011 Female reproductive maturation in the absence of kisspeptin/GPR54 signaling. Nat Neurosci 14:704-710

2. Merkley CM, Coolen LM, Goodman RL, Lehman MN 2011 Direct projections of arcuate kndy (kisspeptin/neurokinin b/dynorphin) neurons to gnrh neurons in the sheep. Society for Neuroscience, Washington, D.C., 2011

3. Garcia-Galiano D, van Ingen Schenau D, Leon S, Krajnc-Franken MA, Manfredi-Lozano M, Romero-Ruiz A, Navarro VM, Gaytan F, van Noort PI, Pinilla L, Blomenrohr M, TenaSempere M 2012 Kisspeptin Signaling Is Indispensable for Neurokinin B, but not Glutamate, Stimulation of Gonadotropin Secretion in Mice. Endocrinology 153:316-328

4. Mitsushima D, Hei DL, Terasawa E 1994 gamma-Aminobutyric acid is an inhibitory neurotransmitter restricting the release of luteinizing hormone-releasing hormone before the onset of puberty. Proc Natl Acad Sci U S A 91:395-399

5. Elias CF 2012 Leptin action in pubertal development: recent advances and unanswered questions. Trends Endocrinol Metab 23:9-15

6. Foradori CD, Amstalden M, Coolen LM, Singh SR, McManus CJ, Handa RJ, Goodman RL, Lehman MN 2007 Orphanin FQ: evidence for a role in the control of the reproductive neuroendocrine system. Endocrinology 148:4993-5001

7. An XF, Chen HP, Ma SL, Feng Y, Hao JW, Chen BY 2005 Involvement of nociceptin/orphanin FQ in release of hypothalamic GnRH mediated by ORL1 receptor in ovariectomized rats. Acta Pharmacol Sin 26:1039-1044

8. An XF, He M, Feng Y, Feng H, Yu JY 2009 Central administration of Orphanin FQ inhibits GnRH secretion by ORL1 receptor in the median eminence of freely moving ovariectomized rats. Neurosci Bull 25:1-6

9. Goodman RL, Coolen LM, Anderson GM, Hardy SL, Valent M, Connors JM, Fitzgerald ME, Lehman MN 2004 Evidence that dynorphin plays a major role in mediating progesterone 
negative feedback on gonadotropin-releasing hormone neurons in sheep. Endocrinology $145: 2959-2967$

10. Maolood N, Meister B 2010 Nociceptin/orphanin FQ peptide in hypothalamic neurones associated with the control of feeding behaviour. J Neuroendocrinol 22:75-82

11. Neal CR, Jr., Akil H, Watson SJ, Jr. 2001 Expression of orphanin FQ and the opioid receptorlike (ORL1) receptor in the developing human and rat brain. J Chem Neuroanat 22:219-249 


\section{PERMISSION TO REPORDUCE COPYRIGHT MATERIALS}

Nestor CC, Seebaugh-Briscoe AM, Davis SM, Valent M, Goodman RL, Hileman SM. 2011. Evidence for a role of kisspeptin and neurokinin B in ovine puberty. Endocrinology 153:2756-65

The Endocrine Society grants permission to reproduce tables/figures Figure 1, Figure 2, Figure 3, Figure 4 and Figure 5 from the selected article stated above contingent upon the following conditions: 1) That you give proper credit to the author(s) and to include in your citation, the title of journal, title of article, volume, issue number, date, and page numbers. 2) That you include the statement Copyright 2012, The Endocrine Society. Please understand that permission is granted for one-time use only. Permission must be requested separately for future editions, revisions, translations, derivative works, and promotional pieces. 


\section{APPENDIX}

\section{SUPPLEMENTAL FIGURE LEGENDS}

Figure 1. LH profiles from individual prepubertal ewes that were treated with acyline and $100 \mu \mathrm{g}$ senktide. Arrows indicate time of IV injection of senktide.

Figure 2. Photomicrographs of kisspeptin-positive neurons in the caudal portion of the ARC from representative young and older males that were intact (A, B) or gonadectomized (C, D). (young ram

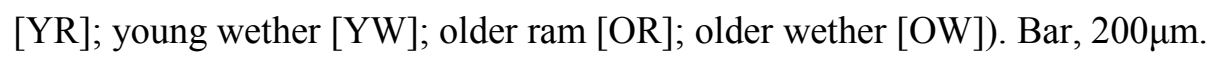

Figure 3. Photomicrographs of kisspeptin immunoreactivity in the POA for an older (>3yrs) adult OVX ewe (A, B) and younger (11 months) EF ewe (C, D). 4x magnification (A, C). 10x magnification (B, D). Bar, $200 \mu \mathrm{m}$.

Figure 4. Photomicrographs of NKB-positive neurons in the caudal portion of the ARC from representative young and older males that were intact (A, B) or gonadectomized $(C, D)$. (young ram

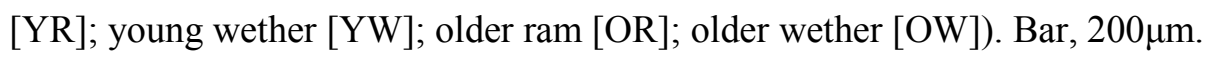




\section{SUPPLEMENTAL FIGURES}

\section{FIGURE 1}

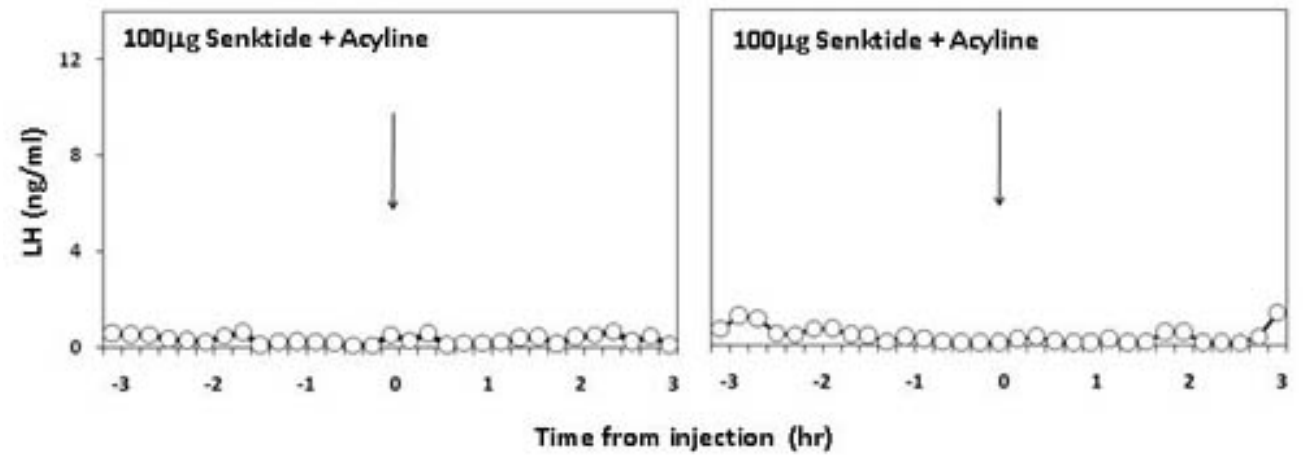


SUPPLEMENTAL FIGURES

FIGURE 2

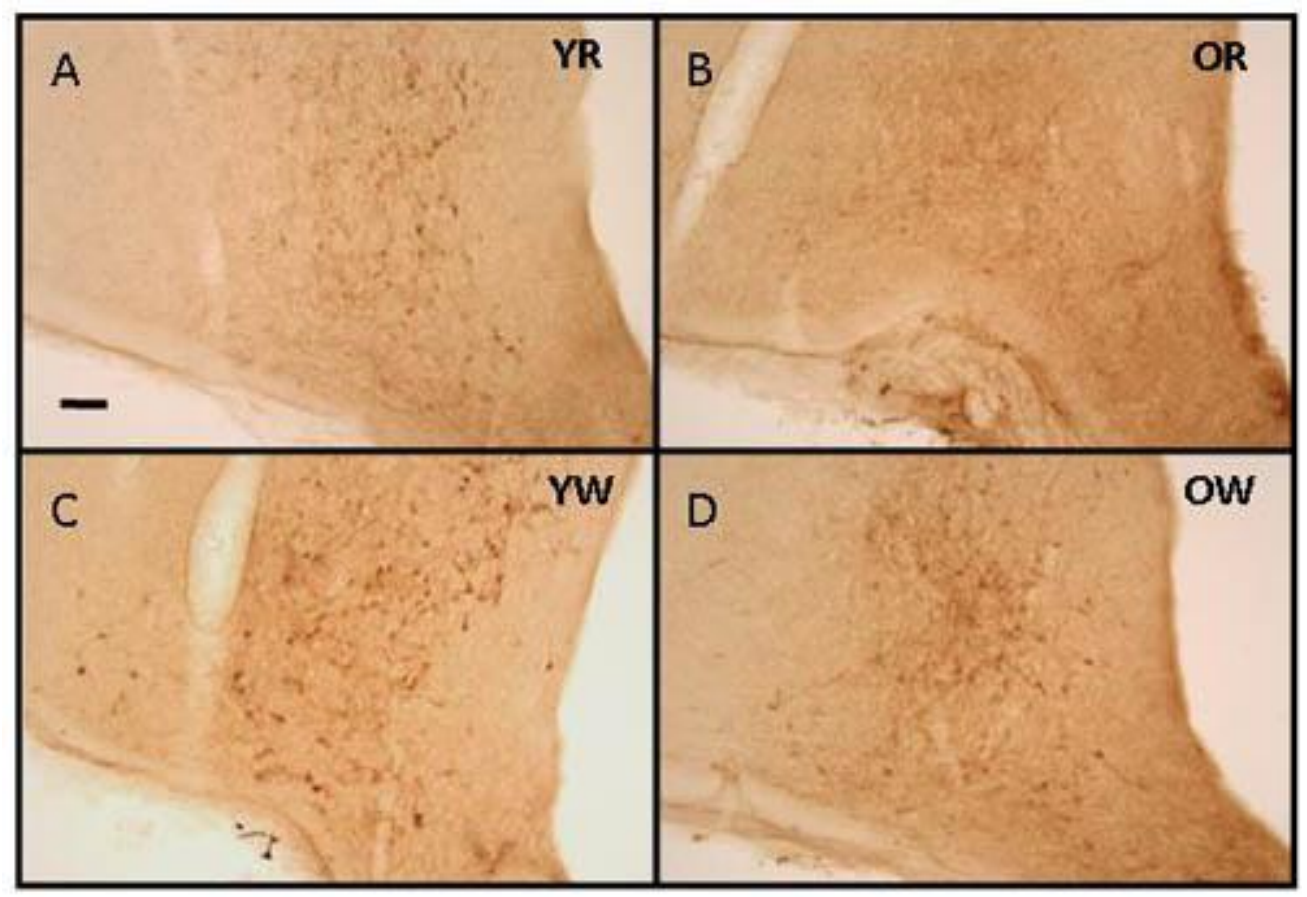


SUPPLEMENTAL FIGURES

FIGURE 3

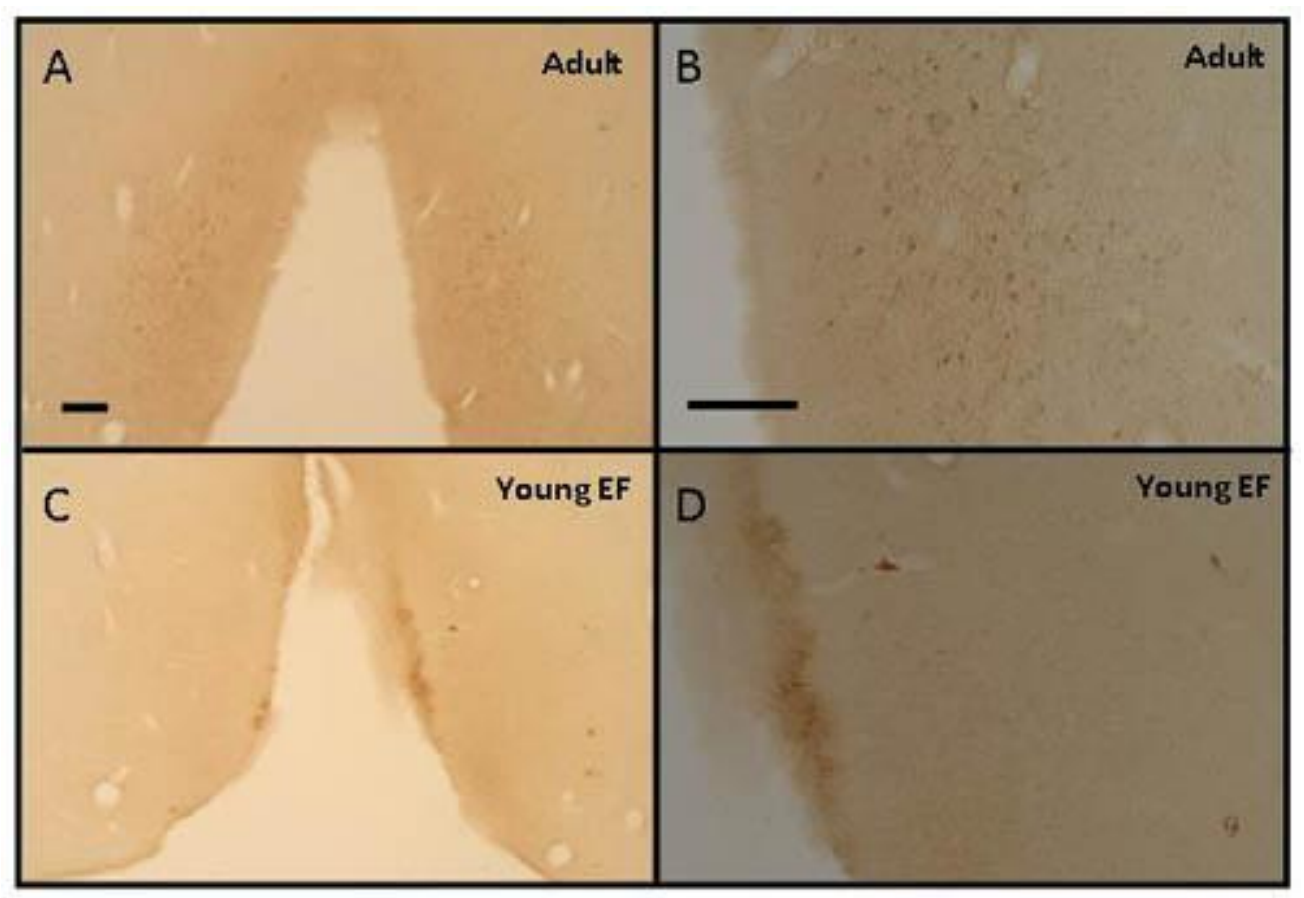




\section{SUPPLEMENTAL FIGURES}

FIGURE 4

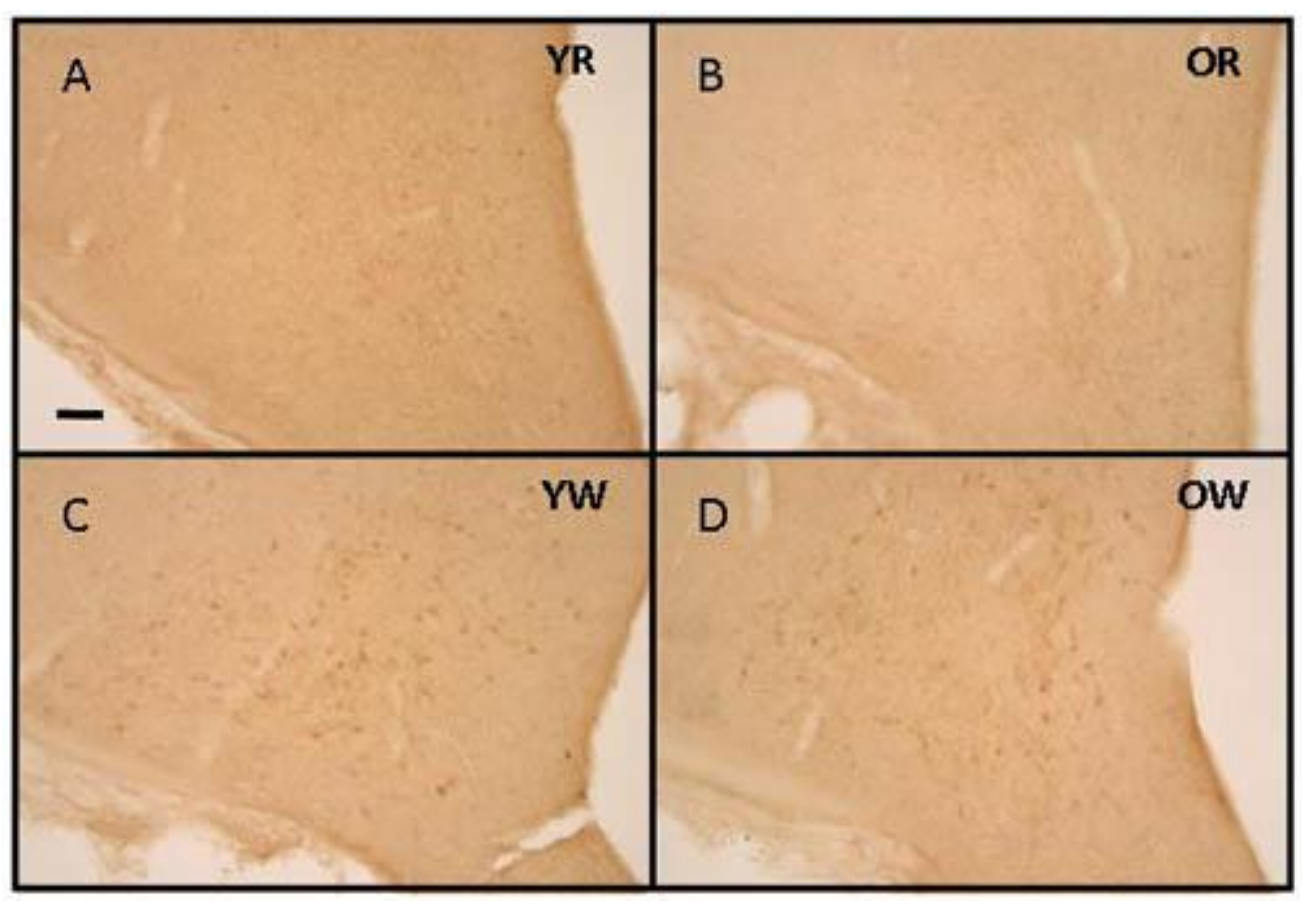




\section{CURRICULUM VITAE}

Date: August 2012

NAME: Casey C Nestor

DATE OF BIRTH: $10 / 10 / 1984$

BIRTH PLACE: Morgantown, West Virginia

HOME ADDRESS: 214 Seemont Dr

Kingwood, WV 26537

WORK ADDRESS: Department of Physiology and Pharmacology

PO Box 9229

West Virginia University

Morgantown, WV 26506

PHONE: $\quad$ (Home) 304-329-0402

(Office) 304-293-1505

(Fax) 304-293-3850

(email) cnestor@hsc.wvu.edu

$\begin{array}{llll}\text { EDUCATION: } & 2005 & \text { B.S. Biology } & \text { West Virginia University } \\ & 2012 & \text { Ph.D. } & \text { West Virginia University }\end{array}$

DOCTORAL ADVISOR: Robert L. Goodman, Ph. D.

DOCTORAL DISSERTATION: Evidence of a Role for Three Neuropeptides that Mediate Steroid Negative Feedback on Gonadotropin Releasing Hormone/Luteinizing Hormone Secretion in the Ewe: Kisspeptin, Neurokinin B and Orphanin FQ

Estradiol and progesterone inhibit tonic GnRH and LH release. Since GnRH neurons are devoid of steroid receptors, this inhibition most likely occurs through afferent neurons that have yet to be identified. My dissertation work focuses on the three neuropeptides which may play a role in mediating steroid negative feedback in sheep, kisspeptin and neurokinin B (NKB) in the context of puberty onset, and orphanin FQ with regard to seasonal breeding.

Puberty in the ewe is marked by an increase in GnRH/LH secretion which results from a lessening of estradiol-negative feedback. Kisspeptin and NKB are coexpressed in the same subsets of neurons in the arcuate nucleus of the hypothalamus and are critical for normal timing of puberty. Given that greater than $95 \%$ of kisspeptin/NKB neurons colocalize with estrogen receptor- $\alpha$ and progesterone receptor in the ewe, we examined changes in kisspeptin and NKB positive neurons in the arcuate of preand post-pubertal ewes in the presence and absence of sex steroids. We observed a greater number of kisspeptin, but not NKB, positive neurons in the arcuate nucleus of postpubertal ewes compared to prepubertal ewes, which corresponded with changes in LH secretion. Also, we showed an intravenous injection of senktide, an NKB receptor agonist, stimulates LH secretion in prepubertal ewes. These results support a role for kisspeptin and NKB in ovine puberty. 
Sheep breed during the shorter days of autumn and are reproductively active in the relatively longer days of summer. This seasonal swing in fertility is primarily due to photoperiod-induced changes in sensitivity to estradiol-negative feedback. We used an OFQ receptor antagonist to examine a role of endogenous OFQ in controlling LH secretion in ewes during the breeding and non-breeding season. We observed an increase in LH pulse frequency in ewes with luteal concentrations of progesterone and estradiol, but no effect on LH secretion in ewes treated with estradiol alone or in intact, anestrous ewes. In addition to our work, icv administration of OFQ has been shown to inhibit LH secretion in the rat and ewe and OFQ localizes in the external zone of the median eminence. Given its effect on LH and its location, we investigated whether OFQ acts at the pituitary to inhibit LH release and/or at the hypothalamus to inhibit GnRH secretion. OFQ had no direct influence on ovine anterior pituitary cells in cell culture. However, we did observe a decrease in GnRH secretion in hypophyseal portal samples following infusion of an OFQ agonist into the third cerebroventricle of ovariectomized ewes. From this we conclude a role for OFQ in mediating, at least in part, progesterone-negative feedback in the ewe at the level of the hypothalamus.

\section{PUBLICATIONS:}

Bogusz AL, Hardy SL, Lehman MN, Connors JM, Hileman SM, Sliwowska JH, Billings HJ, McManus CJ, Valent M, Singh SR, Nestor CC, Coolen LM, Goodman RL 2008 Evidence that gammaaminobutyric acid is part of the neural circuit mediating estradiol negative feedback in anestrous ewes. Endocrinology 149:2762-2772

Lin YC, Huang J, Zhang Q, Hollander JM, Frisbee JC, Martin KH, Nestor C, Goodman R, Yu HG 2010 Inactivation of L-type calcium channel modulated by HCN2 channel. Am J Physiol Cell Physiol 298:C1029-1037

Billings HJ, Connors JM, Altman SN, Hileman SM, Holaskova I, Lehman MN, McManus CJ, Nestor CC, Jacobs BH, Goodman RL 2010 Neurokinin B acts via the neurokinin-3 receptor in the retrochiasmatic area to stimulate luteinizing hormone secretion in sheep. Endocrinology $151: 3836-3846$

Goodman RL, Holaskova I, Nestor CC, Connors JM, Billings HJ, Valent M, Lehman MN, Hileman SM 2011 Evidence that the arcuate nucleus is an important site of progesterone negative feedback in the ewe. Endocrinology 152:3451-3460

Nestor CC, Seebaugh-Briscoe AM, Davis SM, Valent M, Goodman RL, Hileman SM. 2011. Evidence for a role of kisspeptin and neurokinin B in ovine puberty. Endocrinology $153: 2756-65$

\section{PAPERS IN PREPARATION:}

Nestor CC, Singh SR, Holaskova I, Flores JA, Billings HJ, Connors JM, Hileman SM, Goodman RL. 2012. Orphanin FQ Acts at the Hypothalamus to Suppress Gonadotropin Releasing Hormone Secretion in the Ewe.

Nestor CC, Cheng G, Nesselrod GL, Connors JM, Hileman SM, Coolen LM, Lehman MN, Goodman RL. 2012. Evidence that Orphanin FQ Mediates Progesterone Negative Feedback in the Ewe. 


\section{ABSTRACTS/POSTERS:}

Singh SR, McManus CJ, Nestor CC, Connors JM, Lehman MN, Goodman RL 2006 Orphanin-FQ inhibits episodic luteinizing hormone (LH) secretion in ewes. Annual Meeting of the Society for Neuroscience

Pitchers KK, Muscan LM, Cheng G, Coolen LM, Billings HJ, Nestor CC, Goodman RL, Lehman MN 2007 Seasonal changes in the number of kisspeptin-immunoreactive neurons in the ewe: possible role in seasonal reproductive transitions. Annual Meeting of the Society for Neuroscience

Hileman SM, Bogusz AL, Nestor CC, Connors JM, Goodman RL, Billings HJ 2007 Neuropeptide Y (NPY)-1 receptors mediate the suppression of LH secretion by NPY in castrated male sheep. Annual Meeting of the Society for Neuroscience

Nestor CC, Seebaugh A, Valent M, Goodman RL, Hileman SM. 2008. A Potential Role for Kisspeptin in Puberty Onset in Sheep. International Conference of Farm Animal Endo

Nestor CC, Holaskova I, Goodman RL, Billings HJ 2008 Surge-like release of LH following administration of a neurokinin-3 receptor agonist to the retrochiasmatic area of early follicular phase ewes. Annual Meeting of the Society for the Study of Reproduction

Nestor CC, Billings HJ, Hileman SM, Connors JM, Valent M, Salm AK, Flores JA, Lehman MN, Goodman RL. 2009. Orphanin FQ acts primarily at the hypothalamus to inhibit pulsatile LH secretion in sheep. Annual Meeting of the Society for Neuroscience

Billings HJ, Nestor CC, Hileman SM, Geer SN, Valent M, Goodman RL 2009 Estradiol in the arcuate nucleus inhibits LH pulse frequency via a non-dopaminergic pathway in anestrous ewes. Annual meeting of the Society for the Study of Reproduction

Hileman SM, Bassin A, Nestor CC, Billings HJ, Connors JM, Holaskova I, Lehman MN, and Goodman RL 2009 Dopaminergic neurons act in the arcuate nucleus to hold LH pulse frequency in check in anestrous ewes. Annual Meeting of the Society for Neuroscience

Goodman RL, Hileman S, Nestor CC, Holaskova I, Connors JM, Millar RP, Coolen LM, Lehman MN 2009 Kisspeptin actions in the arcuate nucleus of ewes are necessary for episodic GnRH secretion. Annual Meeting of the Society for Neuroscience

Nestor CC, Seebaugh A, Hoffman S, Connors JM, Valent M, Goodman RL, Hileman SM. 2010. Evaluation of Neurokinin B and Kisspeptin Expression Before and After Puberty in Sheep. Annual Meeting of the Society for Neuroscience

Goodman RL, Holaskova I, Nestor CC, Hileman SM, Connors JM, Billings HJ, Valent M, Lehman MN 2010 Evidence that dynorphin neurons in the arcuate nucleus mediate the negative feedback actions of progesterone in the ewe. $7^{\text {th }}$ International Congress of Neuroendocrinology, Rouen, France

Goodman RL, Nestor CC, Connors JM, Holaskova I, Lehman MN 2010 The actions of neurokinin B in the arcuate nucleus are important for episodic LH secretion in ewes. Annual Meeting of the Society for Neuroscience 
Nestor CC, Nesselrod GL, Valent M, Connors JM, Hileman SM, Goodman RL. 2011. Evidence that Orphanin FQ is Important for Progesterone Negative Feedback in Ewes. Annual meeting of the Society for the Study of Reproduction

\section{RESEARCH PRESENTATIONS:}

(2009) $8^{\text {th }}$ International Conference, Slovak Conference of Animal Physiology, Račkova Dolina, Slovakia

\section{TEACHING EXPERIENCE:}

(2007) Small Group Discussion: Topics in Physiological Issues ( $1^{\text {st }}$ year medical students)

(2009) Physiology 441: Adrenal Cortex, Adrenal Medulla, and Male Reproduction for medical technology \& exercise physiology students

(2010) Physiology 241: Metabolism/Diabetes and Contraception for nursing \& other undergraduate students

(2010) Biomedical Sciences 710: Female reproduction for $1^{\text {st }}$ year Ph.D. students

(2010) Physiology 441: Female reproduction and contraception for medical technology \& exercise physiology students

(2011) Physiology 241: Introduction to Endocrinology for nursing \& other undergraduate students

\section{TUTORING EXPERIENCE:}

(2007-2011) Physiology 241: Elementary Physiology for nursing \& other undergraduate students

(2008-2010) Physiology 441: Mechanics of Body Function for medical technology \& exercise physiology students

(2008-2011) Physiology 743: Dental and Pharmaceutical Physiology for $1^{\text {st }}$ year dental and pharmacy students

(2009, 2011) CCMD 730: Physiology in Human Function for $1^{\text {st }}$ year medical students 


\section{RESEARCH/TECHNIQUE EXPERTISE:}

Neurosurgery: stereotaxic insertion of chronic guide tubes into specific brain areas

Hypophyseal portal surgery for measurement of GnRH in portal blood (ovine)

Thyroidectomy (ovine)

Microinjections or microinfusions of neuropeptides or receptor agonists and antagonists into the third or lateral cerebroventricle (ovine)

Stereospecific injections of tract-tracing agents into the ovine hypothalamus

Ovariectomy (ovine)

Insertion of jugular catheters (ovine)

Venipuncture (ovine)

Dissection of murine and ovine hypothalamus

Single- and dual-immunocytochemistry (ICER, GnRH, Kisspeptin, NKB, Dyn, TH, cFos)

Single- and dual-immunofluorescence (GnRH, Kisspeptin) using confocal microscopy

Radioimmunoassay (OFQ, GnRH, LH, Prolactin, Progesterone)

In vitro culturing of dispersed anterior pituitary cells (bovine and ovine) 